\title{
Geochemical constraints on the origin of Mesozoic andesites from the Ningwu basin in the Middle-Lower Yangtze Valley, South China
} Hefei 230026, China

\author{
Long Chen, Yong-Fei Zheng ${ }^{*}, \mathrm{Zi}-\mathrm{Fu}$ Zhao
}

CAS Key Laboratory of Crust-Mantle Materials and Environments, School of Earth and Space Sciences, University of Science and Technology of China,

\footnotetext{
* Corresponding author. E-mail address: yfzheng@ustc.edu.cn
} 
An integrated study of zircon U-Pb ages, Hf-O isotopes, whole-rock major-trace elements and $\mathrm{Sr}-\mathrm{Nd}-\mathrm{Hf}$ isotopes was carried out for Mesozoic andesites from the Ningwu basin in the Middle-Lower Yangtze Valley, South China. The results not only provide insights into the origin of anorogenic magmatism in the Middle-Lower Yangtze Valley but also shed light on the petrogenesis of continental arc andesites in general. The Ningwu andesites are mainly composed of trachyandesite and trachyte, with subordinate of basaltic trachy-andesites. They exhibit variable and low $\mathrm{MgO}$ contents of 0.1-3.7 wt.\% and low $\mathrm{Mg \#}$ values of 1.6-51.2, high $\mathrm{K}_{2} \mathrm{O}$ contents of 2.0-9.9 wt.\%. They are characterized by arc-like trace element distribution patterns, with significant enrichment in LILE and LREE but depletion in HFSE. Furthermore, these rocks exhibit relatively enriched whole-rock $\mathrm{Sr}-\mathrm{Nd}-\mathrm{Hf}-\mathrm{Pb}$ isotope compositions, with initial ${ }^{87} \mathrm{Sr} /{ }^{86} \mathrm{Sr}$ ratios of 0.7050 to 0.7082 , negative $\varepsilon_{\mathrm{Nd}}(\mathrm{t})$ values of -8.1 to -1.8 and negative $\varepsilon_{\mathrm{Hf}}(\mathrm{t})$ values of -6.7 to 0.4 . Zircon $\mathrm{U}-\mathrm{Pb}$ dating yields consistent ages of $128 \pm 2$ to $133 \pm 2$ Ma for magma emplacement through volcanic eruption. The zircon exhibits slightly high $\delta^{18} \mathrm{O}$ values of 5.7 to $7.8 \%$ and variable $\varepsilon_{\mathrm{Hf}}(\mathrm{t})$ values of -5.8 to 0.7 . The all andesites can be categorized into two groups in view of their distinct geochemical compositions, an integrated interpretation of which allows deciphering of their petrogenesis. Group I andesite was produced by a relatively larger extent of partial melting of a more fertile and enriched mantle source that contains a greater amount of phlogopite, whereas Group II andesite was generated by a relatively smaller extent of partial melting of a less fertile and enriched mantle source that contains a less amount of phlogopite. In either case, these two mantle sources are less ultramafic in lithochemistry than normal mantle peridotite due to its reaction with metasediment-derived hydrous felsic melts. This metasomatism would take place during subduction of the Cathaysia oceanic crust beneath the Yangtze Craton in the Neoproterozoic, whereas the Mesozoic mafic magmatism in the Middle-Lower Yangtze Valley is essentially caused by reactivation of the fertile and enriched mantle sources due to lithospheric extension in response to the subduction of Pacific plate beneath the eastern China continent. Therefore, the geochemical compoisiton of andesitesis primarilythat of mantle sources that were generated by reaction of the mantle wedge peridotite with hydrous felsic melts originated from the subducted terrigenous sediment in Andean-type subduction zones, though such sources may be partially melt either immediately following generation or at a later time. Late-stage magma evolution processes such as fractional crystallization and magma mixing would have further modified the lithochemical composition of andesitic rocks, 
52 but they are not the governing factors for their trace element and radiogenic isotope 53 compositions.

54

55 Keywords: Andesitic magmatism; sediment subduction; melt-peridotite reaction; Jiangnan 56 orogen; South China

57 


\section{Introduction}

Plate tectonics theory well explains the origin of arc magmatism in modern convergent plate margins (e.g., Gill, 1981; McCulloch and Gamble, 1991; Stern, 2002). What remains to be resolved are the nature of mantle sources for mafic arc volcanics, the mechanism for incorporation of subducted slab components into the mante sources, and the geochemical differentiation of primitive arc magmas during their ascent prior to eruption on the continental crust (e.g., Grove et al., 2012; Spandler and Pirard, 2013; Zheng et al., 2015). On the other hand, mafic igneous rocks with arc-like geochemistry are common in the continental interior. Because they are far away from modern subduction zones, their petrogenetic link to the plate tectonism is usually considered indirect. One of the typical examples is the large magmatic province of Mesozoic age in South China (e.g., Zhou and Li, 2000; Wu et al., 2005; Zhou et al., 2006; Li and Li, 2007; Wang et al., 2013), which occur as far as $1000 \mathrm{~km}$ away from the trench of the western Pacific zone and cannot be linked to any collisional orogeny in the Mesozoic. The exact mechanism for petrogenesis of such giant anorogenic magmatism is highly debated in the past three decades. One of the hotly debates issue is whether the Mesozoic magmatism would result from direct subduction of the western Pacific slab beneath the eastern China continent, similar to the case in the Andean orogen of western South America (e.g., Zhou and Li, 2000; Li and Li, 2007; Wang et al., 2013). Alternatively, it is ascribed to Mesozoic reactivation of the Precambrian continental margins in response to subduction of the Pacific slab beneath eastern China (e.g., Tang et al., 2012; Zhao et al., 2013; Zheng et al., 2013). A resolution to the two models has great bearing on the origin of magmatic rocks in the continental interior.

Mesozoic magmatism in the Middle-Lower Yangtze Valley (MLYV) is the important component of this giant anorogenic magmatism in South China. Basalts are rarely exposed in this region, whereas andesites are common (Tang et al., 2013; Chen et al., 2014). Because andesites are also of mafic composition, they are one of the most appropriate candidates to evaluate the above two models. However, the majority of previous studies have focused on granitoids of felic composition in this region (Wu et al., 2012 and references therein; Li et al., 2013 and references therein). There are only rare studies of andesites, which have often ascribed their compositional changes to the fractional crystallization of basaltic parental magmas with or without of crustal contamination (e.g., Wang et al., 2006; Tang et al., 2013; Yan et al., 2015). This provides limited constraints on the nature of mantle sources. In contrast, Chen et al. (2014) suggest that these andesites can be directly derived from partial melting of 
the fertile, enriched mantle sources with less ultramfic composition than common arc basalts due to reaction of the mantle wedge peridotite with metasediment-derived hydrous felsic melts. It is the less ultramafic lithology for the mantle sources that makes their derivative melts with andesitic rather than basaltic composition. In this regard, the nature of mantle sources overlying oceanic subduciton channels is the key to the origin of andesites. Although this suggestion was based on a comprehensive geochemical study of andesites in the Luzong basin, it sheds light on the origin of all andesites in the MLYV and continental arc andesites in general.

Mesozoic volcanic rocks are also common in the Ningwu basin, northeast to the Luzong basin in the MLYV. They are also dominated by andesites (Tang et al., 2013). This provides us with an ideal target to test the suggestion of Chen et al. (2014). This paper presents a geochemical study of the Ningwu andesites. In combination with previous data for Mesozoic volcanics in the MLYV and contemporary mafic igneous rocks in its adjacent Dabie orogen, the results provide not only new constraints on the nature of Mesozoic magmatism in the MLYV but also further support to the petrogenetic model of Chen et al. (2014) for andesites above the fossil oceanic subduction zone.

\section{Geological setting and samples}

The MLYV region consists of NEE-trend fault zones between the Jiangnan orogen and the Yangtze Craton (Fig. 1a). This region was thought to be part of the Yangtze Block, but new seismological evidence indicates its strong affinity to the Jiangnan orogen (He et al., 2013). Tectonically, South China is composed of the Yangtze Craton in the northwest, the Cathaysian Block in the southeast and the Jiangnan orogen in between (Charvet, 2013; Zheng et al., 2013). The Jiangnan orogen was built by the arc-continent collision during the accretion of oceanic and continental arc terranes to the Yangtze Craton in the Neoproterozoic following subduction of the Cathaysia oceanic crust beneath the Yangtze Craton (e.g., Zhang et al., 2012; Zhang and Zheng, 2013; Zheng et al., 2013). Afterward, there could be arc-arc collision during accretion of the Cathaysia terrane to the Jiangnan arc terranes (Zhao, 2015). $<$ Figure 1>

The basement rocks of the MLYV and adjacent regions are mainly Proterozoic rocks with rare Archean outcrops (e.g., Chen et al., 2001). The Archean rocks are represented by the Archean TTG gnesis and amphibolite in the Kongling area (e.g., Chen and Jahn, 1998; Chen et al., 2001; Gao et al., 1999; Zhang et al., 2006), and the Paleoproterozoic rocks are 
represented by the Dongling Group feldspathic gneiss and muscovite quartz schist with intercalated amphibolite (e.g., Xing and Xu, 1994). Meso-Neoproterozic rocks are widely distributed in this region, composed of the Banxi, Shangxi and Shuangqiaoshan Groups low-grade metamorphic rocks and volcanic rocks (e.g., Li and Gui, 1991).

The MLYV is characterized by extensive occurrences of Mesozoic magmatic rocks and related ore deposits (Fig. 1a), representing one of the key constitutes for the Mesozoic magmatism in South China (e.g., Zhou and Li, 2000; Wu, 2005; Zhou et al., 2006; Li and Li, 2007; Wang et al., 2013). These magmatic rocks can be temporally divided into three stages: (1) K-rich calc-alkaline diorite, granite, granodiorite, and granodiorite porphyry with adakitic affinity. They are exposed in an uplifted region and are associated with porphyry related, skarn and stratabound $\mathrm{Cu}-\mathrm{Au}-\mathrm{Mo}-\mathrm{Fe}$ mineralization (e.g., Mao et al., 2006, Liu et al., 2010); (2) shoshonitic to calc-alkaline volcanic rocks composed of trachybasalt, basaltic trachyandesite, trachyte, andesite, dacite, rhyolite, trachytic tuff and their corresponding intrusive rocks. They occur in early Cretaceous extensional basins such as the Jingniu basin, the Huaining basin, the Luzong basin, the Fanchang basin, the Ningwu basin, the Lishui basin, and the Liyang basin (e.g., Pan and Dong, 1999; Mao et al., 2011); (3) A-type quartz syenite, syenite, quartz monzonite, alkaline granite, and phonolite (e.g., Zhao et al., 2004; Li et al., 2011). There is the significant evolution of lithochemistry from the first stage through the second stage to the third stage.

This study focuses on andesitic igneous rocks in the Ningwu basin (Fig. 1a), which belongs to the second-stage magmatism in the MLYV. Previous LA-ICPMS and SIMS zircon $\mathrm{U}-\mathrm{Pb}$ dating yields early Cretaceous ages of $135 \pm 1$ to $127 \pm 1 \mathrm{Ma}$ for their magma emplacement (Yan et al., 2009; Hou and Yuan, 2010; Zhou et al., 2011; Tang et al., 2013; Yan et al., 2015). Volcanic rocks in the Ningwu basin cover $\sim 1000 \mathrm{~km}^{2}$ and are mainly composed of shoshonitic trachyandesite, trachyte, dacite, trachytic breccia, and trachytic tuff, with subordinate calc-alkaline basaltic andesite, andesite, dacite and minor rhyolite and phonolite (Fig 1b). Field observations reveal that the Ningwu volcanics can be subdivided into four formations from bottom to top (Fig. 1b), which are named as the Longwangshan formation, the Dawangshan formation, the Gushan formation and the Niangniangshan formation. The contact between each two formations is in the form of eruption uncomformity ( $\mathrm{Ni}$ et al., 1998), and each formation represents an independent volcanic event corresponding to different stages of the pull apart basin (Jiang and $\mathrm{Xu}, 1989$ ) though they are cogenetic rocks with similar lithochemical features (Wang et al., 2001; Tang et al., 2013; Yan et al., 2015). The Longwangshan formation volcanics occur along the eastern margin of the basin, cover $\sim 200$ 
$158 \mathrm{~km}^{2}$ and unconformably overlie Triassic and Jurassic sedimentary rocks; they are mainly 159 composed of trachyandesite and basaltic trachyandesite. The Dawangshan formation 160 volcanics are widespread in the basin, covering $\sim 750 \mathrm{~km}^{2}$ and being mainly composed of 161 trachyandesite, trachyte, andesite, trachytic tuff and trachytic lava. In contrast, exposure of the 162 Gushan and Niangniangshan formations volcanics is very limited $\left(<50 \mathrm{~km}^{2}\right)$. The Gushan 163 formation volcanics are mainly exposed in the southern part of the basin with small outcrops 164 in the northeastern margin of the basin and composed of andesite, tracyandesite and andesitic 165 pyroclastic rocks. The Niangniangshan formation volcanics are exposed in the western margin of the basin and mainly composed of shoshonitic trachyte, trachytic conglomerate, trachytic breccia, and phonolitic breccia tuff.

Andesitic rocks from the Ningwu basin are variably porphyritic with alkali feldspar and plagioclase as the dominant phenocrysts followed by clinopyroxene and biotite (Fig. 2). Fe-Ti oxides, apatite and zircon are main secondary minerals and they ubiquitously occur as inclusions within plagioclase, clinopyroxene or biotite phenocrysts. Plagioclase (50-80 vol \%) is the dominant phenocryst phase, followed by K-feldspar (20-50 vol \%) or clinopyroxene $(\sim 30 \mathrm{vol} \%)$ and biotite $(0-10 \mathrm{vol} \%)$ in all of the samples from the Longwangsan formation, the majority of samples from the Dawangshan formation as well as few samples from the Niangniangshan formation. On the other hand, K-feldspar phenocrysts (50-80 vol \%) are dominant in most of the samples from the Niangniangshan formation and the minority of samples from the Dawangshan formation, with subordinate amounts of plagioclase (5-15 vol \%), clinopyroxene (10-30 vol \%) and biotite ( $\sim 5$ vol \%). Most of the groundmasses are holocrystalline with microlites of plagioclase, clinopyroxene, K-feldspar, biotite, apatite and magnetite.

Selected for the present geochemical study are twenty-three relatively fresh hand specimens from the Longwangshan (4), Dawangshan (16) and Niangniangshan formations (3), which have few or no secondary minerals such as sericite, chlorite, epidote, calcite, clay minerals and iron oxyhydroxides. Because of the rare exposure, we have not had any samples from the Gushan formation for the present study. In order to have a comprehensive knowledge of the geochemical variations in the Ningwu volcanics, the major-trace element and radiogenic isotope data from previous studies are also compiled in this study for comparison.

\section{Analytical methods}


Fresh specimens were sawed into slices and the central parts were selected to crush into powders of $\sim 200$ meshes using the agate mortar in order to minimize the potential contamination of metals. Zircon grains were separated by the conventional magnetic and heavy liquid techniques and hand-picked using a binocular microscope. Representative zircon grains were mounted in epoxy resin, and polished to expose the grain centers. The mount was subsequently vacuum-coated with high-purity gold prior to secondary ion mass spectrometry (SIMS) analysis. Transmitted and reflected light micrographs as well as cathodoluminescence (CL) were taken to reveal their external morphology and internal structure, which then were used as a guide to selection of in-situ analysis spot.

\subsection{Zircon $\mathrm{O}$ isotopes and $\mathrm{U}-\mathrm{Pb}$ ages}

Zircon O isotopes were analyzed using a Cameca IMS 1280 at State Key Laboratory of Lithospheric Evolution in Institute of Geology and Geophysics (IGG), Chinese Academy of Sciences (CAS), Beijing. Analytical procedures are the same as those described in detail by Li et al. (2010a). Measured ${ }^{18} \mathrm{O} /{ }^{16} \mathrm{O}$ ratios were normalized relative to the Vienna standard mean oceanic water (VSMOW), and then corrected for the instrumental mass fractionation (IMF) (Li et al., 2010a), which in turn was corrected using in-house zircon standard Penglai with a recommended $\delta^{18} \mathrm{O}$ values of $5.31 \pm 0.10 \%$ with reference to VSMOW ( $\mathrm{Li}$ et al., 2010b). The $1 \sigma$ internal precision of a single analysis is generally better than $\pm 0.2 \%$ for $\delta^{18} \mathrm{O}$ values. Fifty-one analyses of zircon standard Penglai gave $\delta^{18} \mathrm{O}$ value of $5.25 \pm 0.30 \%$ (2SD, $\left.\mathrm{n}=51\right)$, in excellent agreement with the reference value. The corrected $\delta^{18} \mathrm{O}$ values for samples are reported in the standard per mil notation with $2 \sigma$ errors.

After the $\mathrm{O}$ isotope analysis, the measurements of $\mathrm{U}-\mathrm{Pb}$ isotopes were also conducted at the same domain of the O isotope analysis spot using the Cameca IMS-1280 ion microprobe at State Key Laboratory of Lithospheric Evolution in IGG, CAS, Beijing. The analytical procedures were similar to those described by $\mathrm{Li}$ et al. (2009). U-Th-Pb ratios and absolute abundances were determined relative to the standard zircon 91500 (Wiedenbeck et al., 1995) for their limit heterogeneity ( 15\%) of $U$ and Th contents (Wiedenbeck et al., 2004), analyses of which were interspersed with those of unknown grains, using operating and data processing procedures similar to those described by $\mathrm{Li}$ et al. (2009). Measured compositions were corrected for the common $\mathrm{Pb}$ using non-radiogenic ${ }^{204} \mathrm{~Pb}$. The model crustal $\mathrm{Pb}$ isotope composition of Stacey and Kramers (1975) was used for the common $\mathrm{Pb}$ correction on the assumption that it is largely introduced during the sample preparation due to surface contamination. Uncertainties on individual analyses in data tables are reported at a $1 \sigma$ level; 
mean ages for pooled $\mathrm{U} / \mathrm{Pb}$ (and $\mathrm{Pb} / \mathrm{Pb}$ ) analyses are quoted with $95 \%$ confidence interval. $\mathrm{U}-\mathrm{Pb}$ concordia diagrams and weighted mean calculations were made using Isoplot/Ex_ver3.23 (Ludwig, 2001).

\subsection{Zircon Lu-Hf isotopes}

After the SIMS dating and $\mathrm{O}$ isotope analysis, the Lu-Hf isotope analysis was conducted by LA-MC-ICPMS at State Key Laboratory of Lithospheric Evolution in IGG, CAS, Beijing. A Geolas-193 laser-ablation microprobe was attached to a Neptune multi-collector ICPMS. Lu-Hf isotopic analyses were obtained on the same zircon spots that were previously analyzed for $\mathrm{O}$ and $\mathrm{U}-\mathrm{Pb}$ isotopes, with a beam diameter of $44 \mu \mathrm{m}$ or $60 \mu \mathrm{m}$ and repetition rate of $8 \mathrm{~Hz}$. The detailed analytical procedures were similar to those described by $\mathrm{Wu}$ et al. (2006). The isobaric interference of ${ }^{176} \mathrm{Lu}$ and ${ }^{176} \mathrm{Yb}$ on ${ }^{176} \mathrm{Hf}$ was corrected following the method described in lizuka and Hirata (2005). The standard zircons gave ${ }^{176} \mathrm{Hf} /{ }^{177} \mathrm{Hf}$ ratios of $0.282034 \pm 0.000027(2 \sigma, \mathrm{n}=87)$ and $0.282513 \pm 0.000020(2 \sigma, \mathrm{n}=87)$ for GJ-1 and Mud-Tank during our analysis, which are well consistent with their reference values within analytical errors (Morel et al., 2008; Woodhead and Hergt, 2005). A decay constant of $1.865 \times 10^{-11} /$ year for ${ }^{176} \mathrm{Lu}$ (Scherer et al., 2001) was adopted in this study and the $\varepsilon_{\mathrm{Hf}}(\mathrm{t})$ values were calculated based on the new CHUR value recommend by Bouvier et al. (2008). Single-stage Hf model ages $\left(\mathrm{T}_{\mathrm{DM} 1}\right)$ are calculated relative to the depleted mantle with present-day ${ }^{176} \mathrm{Lu} /{ }^{177} \mathrm{Hf}$ ratio of 0.0384 and ${ }^{176} \mathrm{Hf} /{ }^{177} \mathrm{Hf}$ ratio of 0.28325 (Griffin et al., 2000), and two-stages $\mathrm{Hf}$ model ages $\left(\mathrm{T}_{\mathrm{DM} 2}\right)$ are calculated relative to the average continental crust with ${ }^{176} \mathrm{Lu} /{ }^{177} \mathrm{Hf}$ ratio of 0.015 (Griffin et al., 2002).

\subsection{Whole-rock major and trace elements}

Whole-rock major and trace elements were analyzed at the ALS Chemex Company in Guangzhou, China. An ignited sample ( $\sim 0.9 \mathrm{~g})$ was mixed well with $\sim 9.0 \mathrm{~g}$ lithium borate flux $\left(50 \%-50 \% \mathrm{Li}_{2} \mathrm{~B}_{4} \mathrm{O}_{7}-\mathrm{LiBO}_{2}\right)$ and then fused in an auto fluxer under the temperature of $1050^{\circ} \mathrm{C}$ to $1100^{\circ} \mathrm{C}$. The resulted melt was made into a flat molten glass disc, which then analyzed using X-ray fluorescence spectrometry (XRF) for major elements with the analysis precision better than $\pm 1-2 \%$. Similar to the preparation for major element analysis, a prepared sample $(\sim 0.2 \mathrm{~g})$ was mixed well with lithium metaborate flux $(\sim 0.9 \mathrm{~g})$ and then fused in a furnace at $1000^{\circ} \mathrm{C}$ to obtain the homogeneous melt, which then cooled and dissolved in 100 $\mathrm{ml} 4 \%$ nitric acid before analysis using inductively coupled plasma-mass spectrometry (ICP-MS) for trace elements. For most trace elements, the analytical precision is better than 
$\pm 5 \%$. Standard andesite GSR-2 was simultaneously analyzed to monitor the analytical quality. Trace elements are abbreviated as large ion lithophile elements (LILE), light rare earth elements (LREE), middle rare earth elements (MREE), heavy rare earth elements (HREE) and high field strength elements (HFSE), respectively.

\subsection{Whole-rock Sr-Nd-Hf isotopes}

The Sr-Nd-Hf isotopic analyses were carried out on a Neptune MC-ICP-MS at State Key Laboratory of Lithospheric Evolution in IGG, CAS, Beijing. Chemical separation was undertaken by conventional ion-exchange techniques. The detailed procedure is described by Yang et al. (2010), and only a brief introduction is given here. All chemical preparations were conducted on special class 100 work benches inside a class 1000 clean laboratory. About 100 $\mathrm{mg}$ of rock powder was weighted into a $7 \mathrm{~mL}$ round bottom SavillexTM Teflon screw-top capsule with a mixed concentrate $\mathrm{HF}-\mathrm{HNO}_{3}-\mathrm{HClO}_{4}(2 \mathrm{~mL}-1 \mathrm{~mL}-0.2 \mathrm{~mL})$ and then capped to heat on a hotplate at about $120^{\circ} \mathrm{C}$ for 1 week. After cooling, the capsule was opened and evaporated to fume $\mathrm{HClO}_{4}$, the residue was then added with $6 \mathrm{M} \mathrm{HCl}$ and dried. Finally, the residue was dissolved in $5 \mathrm{~mL}$ of $3 \mathrm{M} \mathrm{HCl}$ after cooled down and then sealed to heat on a hot plate at $\sim 100^{\circ} \mathrm{C}$ overnight before chemical separation. Hf was firstly leached from the solution using the Ln Spec resin (modified after Münker et al., 2001) and then Sr was separated from the remaining solution using a quartz column packed with AG50W-X12. Finally, the separation of $\mathrm{Nd}$ was achieved using another commercial Ln Spec resin column (modified after Pin and Santos-Zalduegui, 1997).

During our analyses, measured ${ }^{87} \mathrm{Sr} /{ }^{86} \mathrm{Sr}$ ratios for standard NBS987 are $0.710261 \pm$ $0.000029(2 \sigma, \mathrm{n}=4)$, measured ${ }^{143} \mathrm{Nd} /{ }^{144} \mathrm{Nd}$ ratios for the La Jolla standard are $0.511878 \pm$ $0.000025(2 \sigma, \mathrm{n}=3)$ and the measured ${ }^{176} \mathrm{Hf} /{ }^{177} \mathrm{Hf}$ ratios for standard BCR-2 are $0.282856 \pm$ 0.000013. All of them are identical to their reference values $(0.710250 \pm 0.000012,0.511853$ \pm 0.000016 and $0.282870 \pm 0.000008$ for NBS987, La Jolla and BCR-2, respectively) within analytical errors (Weis et al., 2005, 2007). Further details on the analytical techniques about Sr-Nd-Hf isotope were given in Wu et al., 2006 and Yang et al., 2009. Parent/daughter ratios for the above isotope couples ( $\mathrm{Rb}-\mathrm{Sr}, \mathrm{Sm}-\mathrm{Nd}$ and $\mathrm{Lu}-\mathrm{Hf}$ ) were determined by the solution ICP-MS method with the analytical precision better than $\pm 5 \%$ for these elements, which is precise enough for age corrections.

The decay constants used for age calculations are: $\lambda\left({ }^{87} \mathrm{Rb}\right)=1.393 \times 10^{-11} \mathrm{y}^{-1}$ (Nebel et al., 2011), $\lambda\left({ }^{147} \mathrm{Sm}\right)=6.54 \times 10^{-12} \mathrm{y}^{-1}\left(\right.$ Lugmair and Marti, 1978) and $\lambda\left({ }^{176} \mathrm{Lu}\right)=1.865 \times 10^{-11} \mathrm{y}^{-1}$ (Scherer et al., 2001). Initial ${ }^{143} \mathrm{Nd} /{ }^{144} \mathrm{Nd}$ and ${ }^{176} \mathrm{Hf} /{ }^{177} \mathrm{Hf}$ ratios were calculated with reference 
293

294

295

296

297

298

299

300

301

302

303

304

305

306

307

308

309

310

311

312

313

314

315

316

317

318

319

320

321

322

323

324

325

to the chondritic reservoir (CHUR) of Bouvier et al. (2008) at the time of magma solidification and denoted in the $\varepsilon_{\mathrm{Nd}}(\mathrm{t})$ and $\varepsilon_{\mathrm{Hf}}(\mathrm{t})$ notation, respectively. Single-stage $\mathrm{Nd}$ and Hf model ages $\left(\mathrm{T}_{\mathrm{DM} 1}\right)$ are calculated relative to the depleted mantle (DePaolo, 1988) with present-day ${ }^{143} \mathrm{Nd} /{ }^{144} \mathrm{Nd}=0.51315,{ }^{176} \mathrm{Hf} /{ }^{177} \mathrm{Hf}=0.28325$ and a ${ }^{147} \mathrm{Sm} /{ }^{144} \mathrm{Nd}=0.2137$ (Gallet et al., 1996), ${ }^{176} \mathrm{Lu} /{ }^{177} \mathrm{Hf}=0.0384$ (Griffin et al., 2000). The two-stages Nd and Hf model ages $\left(\mathrm{T}_{\mathrm{DM} 2}\right)$ are calculated relative to the average continental crust with ${ }^{147} \mathrm{Sm} /{ }^{144} \mathrm{Nd}=0.118$ (Jahn and Condie, 1995) and ${ }^{176} \mathrm{Lu} /{ }^{177} \mathrm{Hf}=0.015$ (Griffin et al., 2002).

\section{Results}

Four samples were selected for the SIMS zircon U-Pb dating and $\mathrm{O}$ isotope as well as LA-ICP-MS Lu-Hf isotope analysis. All twenty-three samples from the Ningwu andesites were analyzed for major and trace element compositions, and fourteen of them were further analyzed for their Sr-Nd-Hf isotopes. All the analytical data are provided in supplementary Tables S1 to S5. Previously published data of major-trace elements and Sr-Nd-Pb isotopes for the Ningwu volcanics are compiled together with those from this study in order to achieve a comprehensive understanding of the geochemistry of these volcanic rocks.

\subsection{Zircon $\mathrm{U}-\mathrm{Pb}$ ages}

Four samples from the Dawangshan formation (13NW02A, trachyte; 13NW07, trachyte; 13NW45A, trachyandesite) and the Niangniangshan formation (13NW12A, trachyte) were selected for the zircon $\mathrm{U}-\mathrm{Pb}$ dating. Zircon grains are colorless and transparent, euhedral to subeuhedral, predominantly elongate to acicular in shapes, they have grain sizes of 80 to 300 $\mu \mathrm{m}$ with length to width ratios of 1:1 to 3:1 (supplementary Fig. S1). Most of these zircon grains show typical oscillatory and sector zoning, which is of magmatic origin. Some zircon grains contain rounded residual cores with narrow overgrowth rim (Fig. S1).

As illustrated in Tables 1 and S1 and Fig. 3, the SIMS zircon U-Pb dating for the four samples yields concordant $\mathrm{U}-\mathrm{Pb}$ ages with a weighted ${ }^{206} \mathrm{~Pb} /{ }^{238} \mathrm{U}$ mean of $128 \pm 2 \mathrm{Ma}(\mathrm{n}=10$, MSWD=1.2) for trachyte 13NW02A, 130 $\pm 2 \mathrm{Ma}(\mathrm{n}=14, \mathrm{MSWD}=2.1)$ for trachyte 13NW07 and $133 \pm 2 \mathrm{Ma}(\mathrm{n}=10, \mathrm{MSWD}=1.4)$ for trachyandesite $13 \mathrm{NW} 45$ from the Dawangshan formation and $129 \pm 1 \mathrm{Ma}(\mathrm{n}=17, \mathrm{MSWD}=1.6)$ for trachyte $13 \mathrm{NW} 12 \mathrm{~A}$ from the Niangniangshan formation. It is worth noting that the ages for the different formations (Dawangshan vs. Niangniangshan) are indistinguishable within analytical errors. Generally, these ages are in agreement with the results from previous geochronometric data (Yan et al., 
2009 and references therein, Hou and Yuan, 2010; Zhou et al., 2011; Tang et al., 2013; Yan et al., 2015).

\section{$<$ Figure 3>}

\subsection{Whole-rock major elements}

Major element data from the present and previous studies are illustrated in Figs. 4 and 5. Most of the samples fall in the alkali field on the total alkali-silica (TAS) diagram with rock types of basaltic trachyandesite, trachyandesite and trachyte. Subordinate samples lie within the sub-alkali field, which are composed of basaltic andesite, andesite and dacite (Fig. 5). These rocks have high $\mathrm{K}_{2} \mathrm{O}$ contents range from 2.0 to 9.9 wt.\% with an average of $5.2 \mathrm{wt} . \%$ and high and variable $\mathrm{K}_{2} \mathrm{O} / \mathrm{Na}_{2} \mathrm{O}$ ratios range from 0.36 to 34.32 with an average of 2.94. (Table S2). Most of these samples lie within the shoshonitic field on the diagram of $\mathrm{K}_{2} \mathrm{O}$ and $\mathrm{SiO}_{2}$ (Fig. 5f). In general, the Ningwu volcanics have low $\mathrm{MgO}$ contents between 0.1 to 3.7 wt. $\%$ with an average of 1.7 wt. $\%$ and low $\mathrm{TiO}_{2}$ contents between 0.5 and 1.0 wt. $\%$ with an average of 0.7 wt. $\%$ (Figs. $5 \mathrm{a}$ and $5 \mathrm{~g}$ ). The $\mathrm{Fe}_{2} \mathrm{O}_{3}{ }^{\mathrm{T}}$ and $\mathrm{Al}_{2} \mathrm{O}_{3}$ contents of these lavas are highly variable (2.5 to 13.8 for $\mathrm{Fe}_{2} \mathrm{O}_{3}{ }^{\mathrm{T}}$ wt.\% and 12.0 to 21.6 wt. $\%$ for $\mathrm{Al}_{2} \mathrm{O}_{3}$ ), both of them decrease generally with increasing $\mathrm{SiO}_{2}$ contents (Figs. 5b and 5d). The $\mathrm{CaO}, \mathrm{Na}_{2} \mathrm{O}, \mathrm{K}_{2} \mathrm{O}$, $\mathrm{P}_{2} \mathrm{O}_{5}$ contents of these samples show no clear correlation patterns with increasing $\mathrm{SiO}_{2}$ contents (Figs. 5c, 5e, 5f and 5h). It is worth pointing out that all these volcanics have large range of major element compositions at certain $\mathrm{SiO}_{2}$ content, some of which are comparable to the whole compositional range of the rocks in this region (Fig. 5).

$<$ Figures 4 and 5>

\subsection{Whole-rock trace elements}

On the chondrite-normalized REE diagram (Fig. 6a), all the samples exhibit similar REE distribution patterns with moderately steep LREE to MREE patterns, flat MREE to HREE patterns, and most of them have negligible negative Eu anomalies ( $>0.85)$ with a mean value of 0.90 (Table S2). On the primitive mantle-normalized diagram, the volcanics exhibit typical arc-like distribution patterns with enrichment of $\mathrm{Rb}, \mathrm{U}, \mathrm{K}$, and $\mathrm{Pb}$ but depletion of $\mathrm{Nb}, \mathrm{Ta}$ and Ti relative to their neighbor elements (Fig. 6b). As shown in Fig. 5g and $6 \mathrm{~h}$ and Table S2, most of the samples have quite low contents of compatible trace elements, with $\mathrm{Cr}$ and $\mathrm{Ni}$ below $20 \mathrm{ppm}$. Similar to the major elements, the compositional variations in most of the trace elements at a certain $\mathrm{SiO}_{2}$ content are comparable to the variations of whole-rock in this region. 
$<$ Figure 6>

\subsection{Whole-rock Sr-Nd-Hf-Pb isotopes}

The Sr-Nd-Hf-Pb isotopic data for the Ningwu volcanics from the present and previous studies (including $\mathrm{Pb}$ isotope data) are plotted in Fig. 7 and the isotopic data for contemporary mafic volcanics from the MLYV and Dabie orogen are also presented for comparison. The Ningwu volcanics exhibit enriched Sr-Nd-Hf isotope characteristics with $\left({ }^{87} \mathrm{Sr} /{ }^{86} \mathrm{Sr}\right)_{\mathrm{i}}$ ratios of 0.7053 to $0.7073, \varepsilon_{\mathrm{Nd}}(\mathrm{t})$ values of -8.07 to -2.44 and two-stage $\mathrm{Nd}$ model ages of 1.13 to 1.59 $\mathrm{Ga}$, and $\varepsilon_{\mathrm{Hf}}(\mathrm{t})$ values of -6.67 to -1.33 and two-stage $\mathrm{Hf}$ model ages of 1.13 to $1.58 \mathrm{Ga}$ (Table S3). There are high ${ }^{207} \mathrm{~Pb} /{ }^{204} \mathrm{~Pb}$ ratios of $15.47-15.61$ and ${ }^{208} \mathrm{~Pb} /{ }^{204} \mathrm{~Pb}$ ratios of $37.75-38.44$ at given ${ }^{206} \mathrm{~Pb} /{ }^{204} \mathrm{~Pb}$ ratios of $17.76-18.28$. It is notable that the $\mathrm{Nd}-\mathrm{Hf}$ isotopic compositions of the Ningwu andesites show some extent of decoupling from each other. This is characterized by ubiquitous positive $\Delta \varepsilon_{\mathrm{Hf}}(\mathrm{t})$ values of 1.27 to 7.47 with an average of 3.71 (Table $\mathrm{S} 3$ and Fig. $7 b)$, where $\Delta \varepsilon_{\mathrm{Hf}}(\mathrm{t})$ values are defined as deviation of $\varepsilon_{\mathrm{Hf}}(\mathrm{t})$ values from the Nd-Hf mantle array (Vervoort et al., 1999).

\subsection{Zircon O isotopes}

A total of 94 in situ $\mathrm{O}$ isotope analyses were made on 94 zircon grains in samples 13NW02A, 13NW07 and 13NNW45A from the Dawangshan formation and in sample 13NW12A from the Niangniangshan formation (Table 1). Representative analysis spots and measured values on CL images are illustrated in Fig. S1 in association with $\mathrm{U}-\mathrm{Pb}$ ages and initial Hf isotope ratios. For sample 13NW02A, synmagmatic zircons (zircons with concordant $\mathrm{U}-\mathrm{Pb}$ ages of $\sim 130 \mathrm{Ma}$ ) show $\delta^{18} \mathrm{O}$ values of 6.4 to $7.2 \%$ with an average of $6.8 \%$ $(\mathrm{n}=10)$. Analysis spots without $\mathrm{U}-\mathrm{Pb}$ ages give $\delta^{18} \mathrm{O}$ values of 6.1 to $7.6 \%$ with an average of $6.8 \%(\mathrm{n}=11)$, identical to the synmagmatic zircons. Because these zircons exhibit similar shapes and textural features to the synmagmatic zircons in the CL images (not shown), it is expected that these zircons are also of synmagmatic origin. All the analysis spots have a narrow $\delta^{18} \mathrm{O}$ range from 6.1 to $7.6 \%$ with an average of $6.8 \%(\mathrm{n}=21)$. For sample 13NW07, synmagmatic zircons show $\delta^{18} \mathrm{O}$ values of 6.3 to $7.3 \%$ with an average of $6.6 \%$ o $(n=18)$. Analysis spots without $\mathrm{U}-\mathrm{Pb}$ ages show $\delta^{18} \mathrm{O}$ values of 6.1 to $7.3 \%$ with an average of $6.7 \%$ $(n=11)$, quite similar to the synmagmatic zircons. All the analysis spots together have a $\delta^{18} \mathrm{O}$ range from 6.1 to $7.3 \%$ with an average of $6.7 \%$ o $(n=29)$. For sample 13NW45A, synmagmatic zircons show $\delta^{18} \mathrm{O}$ values of 6.0 to $6.5 \%$ with an average of $6.2 \%$ o $(n=15)$. Two 
spots without $\mathrm{U}-\mathrm{Pb}$ ages have $\delta^{18} \mathrm{O}$ values of 5.9 and $6.3 \%$ with an average of $6.1 \%$. All these spots have a $\delta^{18} \mathrm{O}$ range from 5.7 to $6.5 \%$ with an average of $6.2 \%$ o $(\mathrm{n}=17)$. For sample $13 \mathrm{NW} 12 \mathrm{~A}$, synmagmatic zircons show $\delta^{18} \mathrm{O}$ values of 6.1 to $7.8 \%$ with an average of $6.8 \%$ $(\mathrm{n}=19)$. Analysis spots without $\mathrm{U}-\mathrm{Pb}$ ages have $\delta^{18} \mathrm{O}$ values of 6.1 to $7.1 \%$ with an average of $6.4 \%$ o $(n=7)$, similar to the synmagmatic zircons. Taken together, all the analysis spots have a $\delta^{18} \mathrm{O}$ range from 6.1 to $7.8 \%$ with an average of $6.7 \%$ o $(\mathrm{n}=26)$.

Generally, the in-situ SIMS $\delta^{18} \mathrm{O}$ data on all the synmagmatic zircons show $\delta^{18} \mathrm{O}$ values ranging from 5.7 to $7.8 \%$ (Table $\mathrm{S} 4$ and Fig. 8). There is no systematic difference in $\delta^{18} \mathrm{O}$ values between the samples from the Dawangshan and Niangniangshan formations. All these $\delta^{18} \mathrm{O}$ values are systematically higher than the recommend value of $5.3 \pm 0.3 \%$ (Valley et al., 1998) for the zircon that crystallized in the mantle with $O$ isotope composition in equllibrium with mantle peridotite (hereafter called normal mantle zircon), but comparable with those whole-rock values of continental arc andesites (Bindeman, 2008). Because of the oxygen isotope fractionation between zircon and andesitic melt (Zhao and Zheng, 2003), whole-rock $\delta^{18} \mathrm{O}$ values for the Ningwu volcanics would be slightly different from the zircon $\delta^{18} \mathrm{O}$ values. $<$ Figure 8>

\subsection{Zircon Hf isotopes}

Zircon Lu-Hf isotope analyses were made for three of the four samples that were previously performed for the $\mathrm{O}$ isotope analysis and $\mathrm{U}-\mathrm{Pb}$ dating, the results are listed in Tables S5 and illustrated in Figure 9.

$<$ Figure 9>

Ten analyses were made on ten zircon grains for sample $13 \mathrm{NW} 02 \mathrm{~A}$, yielding $\varepsilon_{\mathrm{Hf}}(\mathrm{t})$ values of -3.9 to -1.2 and two-stage Hf model ages of 1253 to $1427 \mathrm{Ma}$ (Figs. 9a and 9b). Eighteen analyses on eighteen zircon grains for sample 13NW07 gave $\varepsilon_{\mathrm{Hf}}(\mathrm{t})$ values of -4.1 to 0.7 and two-stage Hf model ages of 1139 to 1442 Ma (Figs. 9c and 9d). Eighteen analyses were made on eighteen zircon grains for sample $13 \mathrm{NW} 12 \mathrm{~A}$, yielding $\varepsilon_{\mathrm{Hf}}(\mathrm{t})$ values of -5.8 to -0.1 and two-stage Hf model ages of 1184 to $1552 \mathrm{Ma}$ (Figs. 9e and 9f). Generally, the zircon Hf isotope compositions are heterogeneous within samples, but quite similar to each other in term of mode values for single samples.

\section{Discussion}

\subsection{Eruption age of the Ningwu andesites}


Early studies, based on whole-rock $\mathrm{Rb}-\mathrm{Sr}$ isochron and $\mathrm{K}$-Ar dating, reported a wide range of ages from 136 to 91 Ma for eruption of the Ningwu andesites (Yan et al., 2009, and references therein). Subsequent studies reported zircon $\mathrm{U}-\mathrm{Pb}$ ages of $135 \pm 1$ to $127 \pm 1 \mathrm{Ma}$ by SIMS or LA-ICPMS for these rocks (Zhang et al., 2003; Yan et al., 2009; Hou and Yuan, 2010; Tang et al., 2013; Yan et al., 2015). In the present study, three samples from the Dawangshan formation give concordant $\mathrm{U}-\mathrm{Pb}$ ages of $128 \pm 2 \mathrm{Ma}$ to $133 \pm 2 \mathrm{Ma}$ and one sample from the latest Niangniangshan formation give an age of $129 \pm 1 \mathrm{Ma}$. These new ages are in agreement with the results from previous dates. The important implication of these results is that the zircon $\mathrm{U}-\mathrm{Pb}$ ages for the different formations (Dawangshan vs. Niangniangshan) are indistinguishable within analytical errors, indicating that the intervals between the different volcanic sequences are very short. These dating results further confirm that the Nignwu andesites, like the other mafic volcanics in the MLYV (e.g., Yan et al., 2009 and references therein; Zhou et al., 2011 and references therein), belongs to the giant Late Mesozoic magmatic event in South China (Zhou and Li, 2000; Wu, 2005; Zhou et al., 2006; Li and Li, 2007; Wang et al., 2013).

\subsection{Identification of two groups}

The Ningwu andesites can be categorized into two groups based on the following observations: (1) Group I rocks are significantly lower in alkali (Fig. 4) but higher in $\mathrm{MgO}$, $\mathrm{Fe}_{2} \mathrm{O}_{3}{ }^{\mathrm{T}}, \mathrm{TiO}_{2}, \mathrm{P}_{2} \mathrm{O}_{5}$ contents (Figs. 6a, 6b, 6g and 6h) than Group II rocks; (2) Group I rocks have higher compatible element contents (Figs. 5o and 5p) and lower incompatible elements contents (except LILE) than Group II rocks (Figs. 5i-5p and 6); (3) Group I rocks exhibit less extent of REE differentiation than Group II rocks (Figs. 6a, 10a and 11); (4) Group I rocks are more enriched in whole-rock Sr-Nd-Hf-Pb isotopes than Group II rocks; (5) Group I rocks show systematically larger $\Delta \varepsilon_{\mathrm{Hf}}(\mathrm{t})$ values than Group II rocks (Figs. 7b). A notable feature is that the HFSE and REE contents of Group II rocks are significantly higher than those of Group I rocks (Figs. 5k-5n and 6), whereas the two groups of volcanics show similar LILE contents (Figs. 5I, 5j and 6). Another interesting feature is that the whole-rock geochemical features between these two groups of rocks are distinct from each other, whereas their zircon $\mathrm{U}-\mathrm{Pb}$ and $\mathrm{Hf}-\mathrm{O}$ isotopes compositions are indistinguishable. As can be seen from Tables S2 and S3, although such a kind of category is based on the distinct geochemical features between the two group of rocks, all the samples from the oldest Longwangshan formation are categorized into Group I whereas the majority of samples from the youngest Niangniangshan formation are categorized into Group II, suggesting that there is a petrogenetic relationship 
461

462

463

464

465

466

467

468

469

470

471

472

473

474

475

476

477

478

479

480

481

482

483

484

485

486

487

488

489

490

491

492

493

494

between the sequence and composition of andesitic magmas.

$<$ Figures 10 and 11>

\subsection{Petrogenetic mechanisms}

\subsubsection{The possibility of crustal anatexis}

Underplating of mantle-derived mafic magmas is often hypothesized to induce partial melting of the overlying crustal rocks, giving rise to andesitic to granitic magmas (Chayes, 1963; Huppert and Sparks, 1988; Annen and Sparks, 2002; Annen et al. 2006). This hypothesis has got support from studies of not only natural migmatites (Moyen 2009; Reichardt and Weinberg, 2012) but also experimental petrology on partial melting of crustal rocks (Sen and Dunn 1994; Rapp 1995; Rapp and Watson 1995; Rapp et al. 1999). However, this mechanism is not applicable to Group I andesites in the Ningwu basin for the following reasons: (1) the geochemical features of these andesites are quite similar to the contemporary volcanics from the other basins in the MLYV (e.g., the Luzong basin), showing the dominant occurrence of andesitic to dacitic rocks with minor amounts of basaltic rocks that unquestionably derived from partial melting of ultramafic mantle lithology (Wang et al., 2006; Xie et al., 2011, Tang et al., 2013; Chen et al., 2014); (2) the Sr-Nd isotope compositions of these rocks show no affinity to any of the exposed basement rocks in the MLYV and its adjacent regions (supplementary Fig. S2), including not only Archean TTG gneisses and amphibolite (e.g., Ma et al., 2000), Paleoproterozoic Dongling amphibolite and schist (e.g., Xing and $\mathrm{Xu}$, 1994), Neproterozoic Banxi, Shangxi and Shuangqiaoshan low-grade metamorphic rocks and volcanic rocks (e.g., Li and Gui, 1991) but also Early Cretaceous felsic rocks in Dabie orogen that were derived from partial melting of the subducted Yangtze continental crust (Jahn et al., 1999; Zhao and Zheng, 2009); (3) the Archean high-grade terrane in the Kongling area exhibits very negative zircon $\varepsilon_{\mathrm{Hf}}(\mathrm{t})$ values (e.g., Gao et al., 1999; Zhang et al., 2006), which are significantly lower than those for the Ningwu andesites; (4) adakitic rocks derived from partial melting of the lower continental crust in the MLYV and the Dabie orogen show systematically lower initial ${ }^{206} \mathrm{~Pb} /{ }^{204} \mathrm{~Pb}$ ratios than the Ningwu andesites (Fig. 7c and 7d; Liu et al., 2010). Therefore, the Ningwu andesites cannot be produced by direct melting of the crustal rocks. Instead, they must be derived from partial melting of SCLM sources.

\subsubsection{Fractional crystallization, crustal contamination and magma mixing}

Mantle-derived mafic magmas would have passed through the continental crust to the 
surface after separation from their sources. They are likely to be modified by crystal fractionation and magma mixing, with or without concomitant crustal contamination. All of these processes can significantly change the geochemical composition of primary mafic magmas. Because all Group I andesites have too low Mg\# numbers and compatible element contents to be equilibrium with the normal mantle peridotite (Table 2 and Fig. 5), it is important to assess to which extent their geochemical signature reflects the nature of magma sources, and to which extent and by which process the original signatures could be modified during their ascent en route the continental crust to the surface.

Fractional crystallization, with or without crustal contamination of mantle-derived mafic magmas in the overlying crust is the key concept in the classical model of andesite petrogenesis (Bowen, 1928; Gill 1981; Hildreth and Moorbath, 1988; Plank and Langmuir, 1988). Due to the continuous separation of minerals from mafic magmas, a series of mafic rocks are produced by fractional crystallization of a common parental mafic magma. These rocks would exhibit positive or negative correlation patterns between major-trace elements and differentiation indices such as $\mathrm{SiO}_{2}$ and $\mathrm{Mg \#} \mathrm{(e.g.,} \mathrm{Bowen,} \mathrm{1928;} \mathrm{Munterner} \mathrm{et} \mathrm{al.,} \mathrm{2001;}$ Lee et al., 2014a). For Group I andesites, there are horizontal correlation patterns for most of the element-SiO 2 diagrams (Fig. 5), especially for trace elements. This undisputedly demonstrates that fractional crystallization, if occurred, was not the most important process responsible for the compositional features of these andesites though negative correlation patterns between $\mathrm{Fe}_{2} \mathrm{O}_{3}, \mathrm{Al}_{2} \mathrm{O}_{3}, \mathrm{TiO}_{2}$ and $\mathrm{SiO}_{2}$ apparently point to the fractional crystallization of plagioclase and Fe-Ti oxides. On the other hand, there are large ranges of major-trace element contents at certain $\mathrm{SiO}_{2}$ contents or $\mathrm{Mg \#}$ values (Fig. 5), indicating that the primary melts are highly heterogeneous in major element composition.

While these horizontal correlation patterns in Fig. 5 cannot be caused by fractional crystallization, they can be produced by mixing between two magmas with similar $\mathrm{MgO}, \mathrm{CaO}$, $\mathrm{Na}_{2} \mathrm{O}, \mathrm{K}_{2} \mathrm{O}$ and trace element compositions but distinct $\mathrm{Fe}_{2} \mathrm{O}_{3}, \mathrm{Al}_{2} \mathrm{O}_{3}, \mathrm{TiO}_{2}, \mathrm{SiO}_{2}$ contents and $\mathrm{Mg \#}$ values. The nature of such mixing can be assimilation of crustal materials by mantle-derived mafic magmas in association with fractional crystallization, a classic mechanism of AFC processes (DePaolo, 1981) or mixing between different batches of mantle-derived mafic magmas (e.g., Straub et al., 2011; Lee et al., 2014b). It is reasonable to expect that the mantle derived magmas would have distinct radiogenic isotopes compositions with the assimilated continental crust and different batches of mafic magmas from the same source would have similar radiogenic isotopes compositions though their major-trace element compositions can be quite different from each other. Therefore, the correlation patterns 
between radiogenic isotopes and differentiation indices such as $\mathrm{SiO}_{2}$ contents can be used to discriminate these two processes. As shown in Fig. 12, Group I andesites exhibit a broad range of $\mathrm{Sr}-\mathrm{Nd}-\mathrm{Hf}-\mathrm{Pb}$ isotope compositions, but there are roughly horizontal correlation patterns between $\mathrm{Sr}-\mathrm{Nd}-\mathrm{Hf}-\mathrm{Pb}$ isotopes and differentiation index (i.e., $\mathrm{SiO}_{2}$ ), especially for $\mathrm{Nd}-\mathrm{SiO}_{2}$ (Fig. 12b). Thus, Group I andesites would be unlikely to undergo significant extent of crustal assimilation during the magma ascent to the surface. Therefore, the horizontal patterns in Fig. 5 are most likely produced by the mixing between different batches of magmas that have similar trace and radiogenic isotopes compositions but distinct $\mathrm{SiO}_{2}$ contents and $\mathrm{Mg \#}$ values.

$<$ Figure 12>

In order to place further constraints on the geochemical compositions of Group I andesites and thus the composition of their parental magmas, we have performed thermodynamic modeling on equilibrium crystallization of primitive magmas with a compositional range from K-poor basaltic to K-rich high $\mathrm{Mg}$ andesitic by using the software of MELTS (Gualda and Ghiorso, 2015 and references therein). The composition of starting materials and their sources as well as the physicochemical parameters for this modeling are listed in supplementary Table S6. Since the rare basaltic andesites with relatively low $\mathrm{SiO}_{2}$ contents in the Ningwu basin have $\mathrm{MgO}$ contents that are too low (lower than many of the Ningwu andesites) to be served as the crystallized counterpart of potential parental magmas, the typical arc basalt and high magnesium andesite with compositional equilibrium or near equilibrium with the mantle peridotite, which were extensively used in fractional crystallization experiments, has been selected to represent the parental magmas for Group I andesites. $\mathrm{MgO}$ is the most sensitive major element in tracing the early stage fractional crystallization of mafic magmas due to the high $\mathrm{MgO}$ contents of early crystallized mineral phases (e.g., olivine, pyroxene). On the other hand, one of the most important geochemical feature of Group I andesites is their high $\mathrm{K}_{2} \mathrm{O}$ contents. Thus, the $\mathrm{K}_{2} \mathrm{O}$ contents of primary mafic melts are the most robust index for the presence or absence of K-rich hydrous minerals in mantle sources. For these reasons, we only plot the modeling results of $\mathrm{MgO}$ and $\mathrm{K}_{2} \mathrm{O}$ for Group I andesites in Fig. 13. The modeling results suggest that the $\mathrm{MgO}$ contents of a $\mathrm{K}$-poor mafic primary melt decrease rapidly at the beginning of crystallization (Line 1 in Fig. 13a) and the $\mathrm{K}_{2} \mathrm{O}$ contents of the magma monotonically increase with fractional crystallization (Line 1 in Fig. 13b). Similar to the results of previous studies, the fractional crystallization of basaltic magmas produces a negative correlation pattern between $\mathrm{MgO}$ and $\mathrm{SiO}_{2}$, which is inconsistent with the roughly horizontal pattern for Group I andesites (Fig. 5). Thus, the solely 
563 fractional crystallization of basaltic magmas cannot produce the observed compositional 564 features of Group I andesites. The above discussion suggests that recharge and mixing of different batches of andesitic magmas with different $\mathrm{SiO}_{2}$ contents may produce such correlation patterns. However, the conceptual mixing between the highly evolved low-MgO high- $\mathrm{SiO}_{2}$ magma (produced by a large extent of fractional crystallization of the parental basaltic magma) and the less evolved high $\mathrm{MgO}$ low $\mathrm{SiO}_{2}$ magma (produced by a large extent of fractional crystallization of the parental basaltic magma) would also produce the negative correlation pattern between $\mathrm{MgO}$ and $\mathrm{SiO}_{2}$. Therefore, the observed compositional features for Group I andesites cannot be produced by differentiation from homogeneous basaltic primary melts, no matter through fractional crystallization alone or recharge mixing after fractional crystallization.

< Fig. 13>

On the other hand, fractional crystallization of a primary K-poor andesitic melt shows a differentiation path similar to that of the K-poor basaltic melt. This indicates that the observed compositional features for Group I andesites cannot be produced by differentiation from a homogeneous andesitic primary melt, no matter through fractional crystallization alone or recharge mixing after fractional crystallization. Nevertheless, a melt left behind by fractional crystallization of an andesitic melt exhibits a higher $\mathrm{SiO}_{2}$ content at a certain $\mathrm{MgO}$ or $\mathrm{K}_{2} \mathrm{O}$ content than a melt left behind fractional crystallization of a basaltic primary melt (line 2 in Figs. 13a and 13b). Thus, the horizontal $\mathrm{MgO}-\mathrm{SiO}_{2}$ trend in Fig. 13a can be caused by the conceptual mixing between two batches of magmas from differentiation of andesitic and basaltic parental melts, respectively. However, the $\mathrm{K}_{2} \mathrm{O}$ contents of mixed magmas would be too low to account for Group I andesites since all of these endmembers are extremely low in $\mathrm{K}_{2} \mathrm{O}$ contents (Fig. 13b). In this regard, K-rich basaltic and andesitic primary melts, derived from partial melting of phlogopite-bearing peridotites (Condamine and Médard, 2014), are used for the similar modeling. Similar to the K-poor parental magmas, the observed compositional features for Group I andesites cannot be produced by differentiation from homogeneous basaltic or andesitic primary melts, no matter through fractional crystallization alone or recharge mixing after fractional crystallization. However, the supposed mixing between these K-rich basaltic and andesitic magmas after certain extent of fractional crystallization can account not only for the variations in $\mathrm{MgO}$ contents with $\mathrm{SiO}_{2}$ contents as $\mathrm{K}$-poor basaltic and andesitic melts do, but also for the high $\mathrm{K}_{2} \mathrm{O}$ contents of Group I andesites (shadown areas in Figs. 13a and 13b). Thus, Group I andesites can be interpreted as derivation from the mixing between K-rich basaltic and andesitic magmas that were 
themselves derived from fractional crystallization of basaltic and andesitic primary melts,

598 respectively. The important implications of this modeling are that: (1) although fractional crystallization of small to moderate extent may significantly decrease the $\mathrm{MgO}$ contents of primary mafic melts, it cannot significantly change the $\mathrm{SiO}_{2}$ contents of primary melts before the magma mixing and some of the magmas are initially high in $\mathrm{SiO}_{2}$ contents (i.e., andesitic in composition); (2) the high $\mathrm{K}_{2} \mathrm{O}$ contents of Group I andesites are primarily inherited from their primary melts.

If the above modelling yields reasonable results for andesite petrogenesis, similar $\mathrm{Nd}$ isotope compositions are required for the different batches of primary melts that exhibit different $\mathrm{SiO}_{2}$ contents with a range from basaltic to andesitic composition in order to produce the horizontal correlation pattern between $\varepsilon_{\mathrm{Nd}}(\mathrm{t})$ and $\mathrm{SiO}_{2}$ in Fig. 12b. However, there is the

608

609

610

611

612

613

614

615

616

617

618

619

620

621

622

623

624

625

626

627

628

629

630 decoupling between the radiogenic isotope and major element compositions of primary melts, which is expected to occur if different amounts of crust-derived melts were added to their mantle sources. In this case, the mixing between crust-derived melts and mantle peridotite results in a kind of metasomatic reaction at the slab-mantle interface in the oceanic subduction channel (Zheng et al., 2015). This generates mafic to ultramafic metasomatites with $\mathrm{Nd}$ isotope composition similar to recycled crustal materials because $\mathrm{Nd}$ in the crust-derived melts dominates the budget of $\mathrm{Nd}$ in the metasomatites (Zheng, 2012). In other words, adding variable amounts of the crust-derived melts to the mantle wedge peridotite can generate the mantle sources with consistent $\mathrm{Nd}$ isotope compositions with the melts but a variable composition in major elements such as $\mathrm{SiO}_{2}$. The more the crust-derived melts were added to the mantle sources, the less mafic melts can be produced from partial melting of the mantle sources. Therefore, the horizontal correlation pattern between $\varepsilon_{\mathrm{Nd}}(\mathrm{t})$ and $\mathrm{SiO}_{2}$ for Group I andesites is most likely caused by the source mixing between the subducted crust-derived melts and the mantle wedge peridotite.

The above arguments suggest that the fractional crystallization, though operated during the emplacement of mafic melts for Group I andesites, did not govern their compositions. This is particularly so for melt-mobile incompatible trace elements and their pertinent radiogenic isotopes. In addition, there is no evidence for significant crustal assimilation during the magma emplacement. As such, the compositional variations of Group I andesites are most likely caused by the mixing between cogenetic magmas with a compositional range from K-rich basaltic to andesitic chemistry. Therefore, the high $\mathrm{SiO}_{2}$ contents, the arc-like trace element distribution patterns and the enriched $\mathrm{Sr}-\mathrm{Nd}-\mathrm{Pb}-\mathrm{Hf}$ isotope compositions of Group I andesites are primarily inherited from their mantle source rather than imparted by the 
crustal differentiation during the mafic magma ascent to the surface.

632

\section{Petrogenesis of the Ningwu andesites}

634

635

636

637

638

639

640

641

642

643

644

645

646

647

648

649

650

651

652

653

654

655

656

657

658

659

660

661

662

663

\subsection{Group 1 andesites}

\subsubsection{Geochemistry of the mantle source}

Group I andesites are characterized by the enrichment of $\mathrm{K}_{2} \mathrm{O}$ (Fig. 5f), which is primarily inherited from K-rich primary melts as argued above. Such melts were proposed to derive from partial melting of fertile mantle sources containing one of such K-rich hydrous minerals as phlogopite and amphibole (e.g., Foley, 1992a, b; Foley and Peccerillo, 1992; Turner et al., 1996; Williams et al., 2004). This is because these minerals are the major host not only for K but also for the other LILE in the SCLM. This proposal is supported by experimental studies (Conceicao and Green, 2004; Condamine and Médard, 2014), which confirm that partial melting of phlogopite-bearing peridotites can produce K-rich basaltic and andesitic melts. The exact K-bearing mineral phase in mantle sources can be identified by the trace element composition of mafic volcanics.

Available studies of experimental geochemistry for trace element partitioning during mantle melting indicate that $\mathrm{Ba}\left(\mathrm{D}_{\mathrm{Ba}}{ }^{\mathrm{Ph} / \mathrm{melt}}=3.68\right)$ and $\mathrm{Rb}\left(\mathrm{D}_{\mathrm{Rb}}{ }^{\mathrm{Ph} / \mathrm{melt}}=2.48\right)$ are compatible in phlogopite, $\mathrm{Sr}\left(\mathrm{D}_{\mathrm{Sr}}^{\mathrm{Ph} / \mathrm{melt}}=0.16\right)$ is moderately incompatible in phlogopite, whereas $\mathrm{Ba}$ $\left(\mathrm{D}_{\mathrm{Ba}}{ }^{\mathrm{Amph} / \mathrm{melt}}=0.16\right), \mathrm{Rb}\left(\mathrm{D}_{\mathrm{Rb}}{ }^{\mathrm{Amph} / \text { melt }}=0.20\right)$ and $\mathrm{Sr}\left(\mathrm{D}_{\mathrm{Sr}}{ }^{\mathrm{Amph} / \text { melt }}=0.30\right)$ are moderately incompatible in amphibole (Latourrette et al., 1995). As outlined by Furman and Graham (1999), the breakdown of phlogopite leads to lower $\mathrm{Ba} / \mathrm{Rb}$ ratios and higher $\mathrm{Rb} / \mathrm{Sr}$ ratios (typically $\mathrm{Ba} / \mathrm{Rb}<20$ and $\mathrm{Rb} / \mathrm{Sr}>0.1$ ) in the melts than the breakdown of amphibole (typically $\mathrm{Ba} / \mathrm{Rb}>20$ and $\mathrm{Rb} / \mathrm{Sr}<0.06$ ). Although these experimental products are alkali basaltic melts and a change in melt composition would have some influences on these partition coefficients, it is reasonable to assume that the relative compatibility of these elements would not reverse. As can be seen from Table S2, almost all Group I andesites have relatively high $\mathrm{Rb} / \mathrm{Sr}(>0.1)$ but low $\mathrm{Ba} / \mathrm{Rb}(<20)$ ratios, suggesting that phlogopite rather than amphibole was present as a K-bearing phase in the mantle source.

In addition, Group I andesites exhibit arc-like trace element distribution patterns (Fig. 6b) and enriched radiogenic isotope compositions with moderately high whole-rock $\left({ }^{87} \mathrm{Sr} /{ }^{86} \mathrm{Sr}\right)_{\mathrm{i}}$ ratios, negative $\varepsilon_{\mathrm{Nd}}(\mathrm{t})$ and $\varepsilon_{\mathrm{Hf}}(\mathrm{t})$ values (Fig.7a), elevated ${ }^{207} \mathrm{~Pb} /{ }^{204} \mathrm{~Pb}$ and ${ }^{208} \mathrm{~Pb} /{ }^{204} \mathrm{~Pb}$ ratios at given ${ }^{206} \mathrm{~Pb} /{ }^{204} \mathrm{~Pb}$ ratios (Fig. $7 \mathrm{~b}$ and $7 \mathrm{c}$ ), and negative zircon $\varepsilon_{\mathrm{Hf}}(\mathrm{t})$ values (Fig. 9). These geochemical features are usually referred as "continental crust-like" features (Taylor and 
664

665

666

667

668

669

670

671

672

673

674

675

676

677

678

679

680

681

682

683

684

685

686

687

688

689

690

691

692

693

694

695

696

697

Mclennan, 1985; Rudnick, 1995), and typically found in active or fossil continental arc volcanics (e.g., Chen et al., 2014; Kelemen et al., 2014; Straub et al., 2015; Ducea et al., 2015). Given that the crustal assimilation is insignificant during magma ascent, the most plausible origin of these geochemical features is the inheritance from an enriched mantle source that contains subducted crust-derived components.

\subsubsection{Involvement of the subducted sediment in the mantle source}

Basically, there are two geochemically different types of crustal material in the subducted oceanic slab that are incorporated into the mantle source of arc volcanics: (1) metabasalt-derived aqueous fluids, and (2) metasediment-derived hydrous melts (e.g, Elliot et al., 1997; Elliot, 2003; Spandler and Pirard, 2013; Zheng and Hermann, 2014). Their relative contributions to the mantle source of arc volcanics can be identified by using the diagram of $\mathrm{Ba} / \mathrm{Th}$ versus $(\mathrm{La} / \mathrm{Sm})_{\mathrm{N}}$ ratios because the former has higher $\mathrm{Ba} / \mathrm{Th}$ ratios but lower $(\mathrm{La} / \mathrm{Sm})_{\mathrm{N}}$ ratios than the latter due to the difference in the mobility of these trace elements during metamorphic dehydration and partial melting, respectively (e.g., Kogiso et al., 1997; Rapp et al., 1999; Kessel et al., 2005; Zheng et al., 2011). Barium is a fluid-mobile incompatible trace element and thus susceptible to dissolution in and transport by aqueous fluids. In contrast, Th and La are melt-mobile incompatible trace elements and thus susceptible to dissolution in and transport by hydrous melts at elevated temperatures (Kelemen et al., 2003; Zheng and Hermann, 2014). Thus, decreased $\mathrm{Ba} / \mathrm{Th}$ ratios indicate enhanced contributions from the hydrous melts; so do increased $(\mathrm{La} / \mathrm{Sm})_{\mathrm{N}}$ ratios.

Group I andesites show low $\mathrm{Ba} / \mathrm{Th}$ ratios and high $(\mathrm{La} / \mathrm{Sm})_{\mathrm{N}}$ ratios (Table $\mathrm{S} 2$ ), suggesting that the metasediment-derived hydrous melts may be the dominant crustal component in their mantle source. This suggestion is consistent with the decoupling between their $\mathrm{Hf}$ and $\mathrm{Nd}$ isotope compositions, which exhibits exclusively positive $\Delta \varepsilon_{\mathrm{Hf}}(\mathrm{t})$ values for Group I volcanics (Table S3 and Fig. 7b). With reference to the mantle Hf-Nd isotope array (Vervoort et al., 1999), the coupling between $\mathrm{Hf}$ and $\mathrm{Nd}$ isotope compositions indicates predominant contributions from the depleted MORB mantle and its derivatives. In contrast, any significant deviation from the mantle array indicates considerable contributions from terrigeneous sediments to magma sources. In particular, positive $\Delta \varepsilon_{\mathrm{Hf}}(\mathrm{t})$ values are ascribed to zircon-poor sediments whereas negative $\Delta \varepsilon_{\mathrm{Hf}}(\mathrm{t})$ values are ascribed to zircon-rich sediments (e.g., Vervoort et al., 1999, 2011; Chauvel et al. 2007; Choi et al. 2013). In this regard, the positive $\Delta \varepsilon_{\mathrm{Hf}}(\mathrm{t})$ values for Group I andesites indicate the incorporation of zircon-poor sediments into their mantle source. 
In addition, Group I andesites show systematically higher zircon $\delta^{18} \mathrm{O}$ values than normal mantle zircon (Fig. 8). This cannot be explained by the fractional crystallization because this process only has an insignificant influence on the $\mathrm{O}$ isotope composition of magmatic rocks (Hoefs, 2009). Thus, the high $\delta^{18} \mathrm{O}$ values would have inherited from their magma sources. However, systematic $\mathrm{O}$ isotope studies of oceanic arc basalts indicate that adding small amounts of slab-derived aqueous fluid or hydrous melts to the mantle wedge peridotite above oceanic subduction zones would not significantly change its $\mathrm{O}$ isotope composition (e.g., Eiler et al., 2001; Bindeman, 2008). High $\delta^{18} \mathrm{O}$ values similar to the Ningwu andesites are common for many of continental arc andesites (Bindeman, 2008), which were argued to be polluted by terrigeneous sediments (either crustal contamination or source mixing) during their genesis (Bindeman, 2008). However, the crustal contamination is insignificant for the petrogenesis of Group I andesites as argued above. Therefore, the high zircon $\delta^{18} \mathrm{O}$ values for Group I andesites suggest that a substantial amount of terrigenous sediment-derived melts were incorporated into their mantle source. This suggestion also has been made by the study of the Ningwu volcanics (Tang et al., 2013) and studies of other Mesozoic mafic volcanics in the MLYV (e.g., Wang et al., 2006; Yan et al., 2008; Xie et al., 2011; Tang et al., 2012; Chen et al., 2014).

The mass transfer from the metasediment to the mantle wedge at subarc depths would elevate the $\mathrm{K}_{2} \mathrm{O} / \mathrm{Na}_{2} \mathrm{O}$ ratios of mantle sources (metasomatites), because the formation of jadeitic clinopyroxene at ultrahigh-pressure conditions reduces the $\mathrm{Na}$ mobility in metasediment-derived melts. Reaction of such K-rich melts with the mantle wedge peridotite would transform olivine into orthopyroxene and hydrous minerals such as K-rich amphibole and phlogopite, leading to the formation of mafic-ultramafic metasomatites such as amphibole- and phlogopite-rich garnet peridotite/pyroxenite or spinel peridotite/pyroxenite in view of experimental petrology (e.g., Sekine and Wyllie, 1982; Castro et al., 2008, 2010, 2013). Such a kind of melt-peridotite reactions also has been recognized in many orogenic peridotites (e.g., Naemura et al. 2009). The resulted metasomatites are fertile in lithochemistry and enriched in melt-mobile incompatible trace elements and their pertinent radiogenic isotopes. Thus, partial melting of such metasomatites would produce geochemically enriched mafic melts with lithochemical compositions varying from basaltic to andesitic (e.g, Sobolev et al., 2007; Condamine and Médard, 2014). The more sediment-derived melts are incorporated into the mantle source, the more fertile the metasomatites are (Chen et al., 2014; Zheng et al., 2015). 


\subsubsection{The onset of andesitic magmatism}

At the beginning of mantle melting in the Early Cretaceous, because of the lower solidus for mafic to ultramafic metasomatites than normal peridotites (e.g., Hirschmann and Stolper, 1996; Lambart et al., 2009), the preferential melting of more fertile and enriched mantle sources that contain relatively larger amounts of the metasediment-derived melts would produce the mafic melt with more enriched radiogenic isotope and trace element compositions as well as high $\delta^{18} \mathrm{O}$ values. Also because of the larger amount of metasediment-derived melts in the mantle source, its derivative melts are expected to exhibit more intensively decoupled Hf-Nd isotope compositions. The presence of hydrous minerals such as amphibole and phlogopite in the mantle source can lead to elevated extent of partial melting according to experimental petrology (Conceic and Green, 2004). In particular, the preferential breakdown of phlogopite can release the crustally derived $\mathrm{Pb}$ and other LILE to produce the $\mathrm{Pb}$ isotope and LILE extremely enriched melts. This early stage melting of the more enriched mantle source can readily produce the mafic melts with geochemical features similar to Group I andesites in the Ningwu basin though the simultaneous melting of the less enriched mantle source may produce small amounts of mafic igneous rocks with a compositional affinity to Group II andesites in the Dawanshan formation.

\subsection{Group II andesites}

\subsubsection{Geochemical constraints}

Compared with Group I andesites, Group II andesites are quite homogeneous in lithochemistry and shows a narrow range of $\mathrm{SiO}_{2}$ contents (Table S2 and Fig. 4), which make it hard to evaluate the influences of processes such as fractional crystallization, AFC and magma mixing on their compositions and therefore hard to explore the compositional feature of their potential source. However, Group II andesites are extremely low in $\mathrm{MgO}$ and compatible element contents. In this case, the crystallization of mafic minerals is easy to be recognized. The above MELTS modling results indicate that simple crystallization of K-rich basaltic and/or andesitic magmas can produce the major element composition of these andesites (Fig. 13). In addition, Groups II and I andesites were temporally produced by the same magmatic event, petrogenetic processes for Group II andesites are expected to be, to first order, similar to those for Group I andesites. In other word, Group II andesites may be also influenced by such crustal processes as fractional crystallization and/or recharge of the primary magmas after the magmas were produced by partial melting of the metasediment-derived melt-metasomatized mantle source. However, the compositional 
differences between Group I and Group II andesites are prominent, not only in major and trace elements (Figs. 4, 5, 6, 10 and 11) but also in radiogenic isotopes (Fig. 7). Such compositional differences may be either inherited from inherently heterogeneous mantle sources combined with different extent of partial melting or produced by differential differentiation of the common parental magmas. Thus, discrimination between these two processes is a key to the origin of Group II andesites.

Group II andesites are relatively enriched in total alkali, $\mathrm{SiO}_{2}$ and incompatible trace elements but depleted in $\mathrm{MgO}, \mathrm{FeO}, \mathrm{CaO}$ and $\mathrm{Cr}$, Ni over Group I andesites. Such differences are consistent with the interpretation that Group II andesites are derived from fractional crystallization of Group I andesitic melts without crustal contamination. Although the more evolved composition of Group II andesites can be caused by larger extent of fractional crystallization, the fractional crystallization alone cannot account for their dramatically enriched incompatible element composition over Group I andesites (Figs. 5 and 6). In addition, the less enriched nature of Group II andesites undisputedly rules out the possibility of fractional crystallization (Fig. 7). Therefore, such compositional differences between Groups II and I andesites are primarily inherited from their mantle sources. As stated above, Group II andesites are more enriched in melt-mobile incompatible trace elements than Group I andesites, but they are less enriched in radiogenic isotope compositions. Such a kind of the decoupling cannot occur in the subduction-zone processes but may be caused by partial melting of the metasomatites. If the mantle source of Group II andesites is less enriched than that of Group I andesites, the similar degrees of partial melting would produce primary mafic melts for Group II andesites that are less enriched than Group I andesites in both incompatible elements and radiogenic isotopes. However, if the degree of partial melting decreases, the incompatible trace element contents can increase; when the melting degree is low enough, it may produce mafic melts with incompatible element contents that are higher in the primary melts of Group II andesites than those of Group I andesites.

On the other hand, the radiogenic isotope composition of mafic melts are consistent with that of their mantle sources and would not change with a change in the degree of partial melting. In this regard, a combination in the mantle source heterogeneity and the difference in the degree of partial melting can lead to the observed compositional differences between Group II and Group I andesites. As such, the observation that all the volcanics from the oldest Longwanshan formation belongs to Group I andesites and most of the volcanic rocks from the youngest Niangniangshan formation belong to Group II andesites suggest that Group II andesites would be produced in a later stage than Group I andesites. This is consistent with 
the results from experimental petrology that less fertile and enriched sources have higher solidus temperatures and therefore start to melting later than more fertile sources (e.g., Hirschmann and Stolper, 1996; Lambart et al., 2009). Considering that there is a large amount of sediment-derived melts in the mantle source of Group I andesites as argued above, the less enriched property of the mantle source for Group II andesites is most likely caused by the less addition of metasediment-deived melts to the mantle source than that for Group I rocks. This is confirmed by the relatively lower $\Delta \varepsilon_{\mathrm{Hf}}(\mathrm{t})$ values for Group II andesites (Table S3 and Fig. 7b) because this parameter is a sensitive index for involvement of zircon-poor metasediment-derived melts in the mantle sources (e.g., Vervoort et al., 1999, 2011; Chauvel et al. 2007; Choi et al. 2013).

It is worthnoting that although the above petrogenetic model can account for the majority of compositional differences between Group I and Group II andesites, it still cannot explain why the LREE and HFSE contents of Group II andesites are remarkably higher than those of Group I andesites (Figs. 5k-p and 6) whereas their LILE contents are comparable with those of Group I andesites (Figs. 5i, 5j and 6). Such a kind of the decoupling between LREE, HFSE and LILE is puzzling since these elements usually behave similarly in most of the high-T geological processes due to their similar compatibilities (Blundy and Wood, 2003). Since LILE are primarily carried by hydrous minerals like phlogopite or amphibole (phlogopite in this case as stated above) in the mantle sources, the proportion of which in the mantle sources during partial melting will govern the LILE contents but not the HFSE and REE contents of the resulted melts. Therefore, we assume that there are less amounts of phlogopite in the mantle source of Group II andesites, which may be caused either by the less amount of metasediment-derived melts in their mantle source or by the consumption of phlogopite during the early stage mantle melting in producing Group I andesites, given that phlogopite is prefered to join the mantle melting at the very beginning (e.g., Conceic and Green, 2004; Condamine and Médard, 2014).

\subsubsection{Petrogenetic mechanism}

The above arguments indicate that the origin of Group II andesites is closely related to the origin of Group I andesites, and they both were derived from partial melting of the similarly fertile and enriched matasomatites. Although such crustal processes as fractional crystallization and magma recharge may have also influenced the final compositions of Group II andesites, their distinct compositional features from Group I andesites are primarily controlled by their mantle geochemistry and partial melting extent. 
Once the mantle temperature increases to higher than the lowest solidus for the most

835 fertile and enriched metasomatite, its partial melting would take place. The early product of the mantle melting would be more enriched in radiogenic isotopes, but not most enriched in incompatible trace elements as discussed above. As the melting continues, the fertile and enriched metasomatite would be consumed gradually to produce Group I andesites, leaving behind the less fertile and enriched metasomatite that contains relatively smaller amounts of hydrous minerals and fertile components. As the mantle temperature would finally reach the solidus temperature for the less fertile and enriched metasomatite, it would undergo lower degree of partial melting (due to its small proportion of phlogopite) to produce the andesitic melts that show less enriched $\mathrm{Sr}-\mathrm{Nd}-\mathrm{Hf}-\mathrm{Pb}$ isotope compositions, especially the obviously less enriched $\mathrm{Pb}$ isotope compositions and higher degrees of REE differentiation than the early stage melts (Fig. 11). These melts also tend to exhibit higher contents of REE and HFSE due to the lower extent of partial melting, but not so much higher contents of LILE such as Rb, $\mathrm{Ba}$ and $\mathrm{Pb}$ due to the less amounts of phlogopite in their mantle source than that for the early stage melting. These late stage melts thus exhibit distinct geochemical features from the early stage melts and subsequently lead to the formation of Group II andesites in the Ningwu basin though the simultaneous melting of the more enriched mantle source may produce a small amount of the mafic melts with a compositional affinity to Group I andesites in the Niangniangshan formation.

853

\subsection{Summary}

As discussed above, although the mixing between different batches of cogenetic magmas may govern the observed compositional features for Group I andesites, the composition of their parental magmas still can be identified to be K-rich basaltic to andesitic in lithochemistry. Group II andesites show more restricted geochemical variations than Group I andesites, but the close temporal and compositional correlations between the two groups of andesites indicate that the mantle source of Group II andesite is, to first order, similar to that of Group I andesites whose parental magmas are K-rich basaltic and/or andesitic in composition. The two groups of andesites are derived from partial melting of the fertial and enriched mantle sources that were generated by interaction between metasediment-derived melts and the mantle wedge peridotite at the slab-mantle interface in the fossil oceanic suduction channel (Chen et al., 2014). Compared with the mantle source of Group I andesites, the mantle source of Group II andesites is less fertile and enriched and contains a small proportion of phlogopite. As such, there would be a less amount of metasediment-derived melts in their mantle source. Therefore, 
868

869

870

871

872

873

874

875

876

877

878

879

880

881

882

883

884

885

886

887

888

889

890

891

892

893

894

895

896

897

898

899

900

the compositional differences between the two groups of andesites are interpreted to indicate the compositional heterogeneity of their mantle sources in addition to the different degrees of partial melting.

\section{Insights into the geological evolution of the MLYV}

\subsection{Tectonic setting of the MLYV}

In the literature, the spatial range of the Jiangnan orogen was hypothesized either as a fault between the Cathaysia Block and the Yangtze Block or as a narrow orogen along the Nanhua Rift with its southeastern margin marked by the Jiangshan-Shaoxing Fault in the east and the Chenzhou-Linwu Fault in the west (e.g., Guo et al., 1985; Zhao and Cawood, 2012; Mao et al., 2013). Nevertheless, the latest studies indicate that the northern margin of the Jiangnan orogen may be extended to the Jiujiang-Shitai Fault and the Ningzhen Mountains in the MLYV of Hubei, Jiangxi, Anhui and Jiangsu provinces and its western margin is extended to the western margin of the Xuefengshan orogen in Jiangxi, Hunan, Guangxi and Guangdong provinces (He et al., 2013; Wang et al., 2013; Yao et al., 2014; Zhang et al., 2015).

Li (1994) noted an east-trending linear aeromagnetic anomaly east of Nanjing, in parallel to the east-trending Mesozoic Ningzhen Mountains. He interpreted this anomaly in the context of the Triassic continental collision between the North and South China Blocks. However, it is well demonstrated that the Dabie-Sulu orogenic belt marks the Triassic continental collision between the North and South China Blocks (Ernst et al., 2007; Zheng et al., 2009). Thus the Triassic suture between the two continental blocks is located along the Wulian-Yantai Fault between the Jiaodong and Jiaobei terrane in the Sulu orogen (Tang et al., 2007, 2008; Zhang et al., 2014). On the other hand, serpentization of peridotite can cause magnetite accumulation and thus magnetic anomalies in the mantle wedge (Hyndman and Peacock, 2003). In this regard, the east-trending linear aeromagnetic anomaly east of Nanjing in parallel to the Ningzhen Mountains may mark the continental margin above the fossil oceanic subduction zone, pointing to the Neoproterozoic suture between the Yangtze Craton and the Jiangnan orogen in the northeastern edge of the Yangtze Block. As such, the northern part of the Jiangnan orogen is represented by Middle-Lower Yangtze fault zones.

Zhao (2015) suggested that volcanic arc assemblages were present not only at the southeastern margin of the Yangtze Block but also at the northwestern margin of the Cathaysia Block. While the author proposed a divergent double-sided subduction model for the formation and evolution of the Jiangnan orogen, it becomes clear that the Jiangnan orogen 
is wider than previously thought. It consists of the volcanic arc belt that was traditionally categorized into the southeastern margin of the Yangtze Block, whereas the Yangtze Craton is composed of Archean-Paleoproterozoic metamorphic complexes in the Yangtze Block. Therefore, the Jiangnan orogen is tectonically bracketed by the Jiujiang-Shitai Fault and its southward extension in the northwest and by the Zhenghe-Dapu Fault in the southeast. As such, the MLYV is the northern part of the Jiangnan orogen adjacent to the southeastern boundary of the Yangtze Craton. Therefore, the Mesozoic reworking of the Jiangnan orogen can be linked to the subduction of Pacific oceanic slab beneath the Cathaysia Block (Zheng et al., 2013),

\subsection{Timing of the crust-mantle interaction for Mesozoic mafic volcanics}

The crust-mantle interaction during plate subduction is generally realized by fluid/melt metasomatism of the mantle wedge peridotite in subduction channels (Zheng, 2012; Zheng et al., 2015). The geochemical features of the Ningwu andesites and the contemporary mafic volcanics from the MLYV indicate incorporation of the metasediment-derived melts into their mantle sources (e.g., Wang et al., 2006; Tang et al., 2013; Chen et al., 2014; Yan et al., 2015; this study). However, it is still highly debated when the crust-mantle interaction takes place (e.g., Yan et al., 2008; Tang et al., 2012, 2013; Li et al., 2013; Chen et al., 2014; Yan et al., 2015). It is known that the South China Block had been a unified block since amalgamation of the Yangtze Craton with the Cathaysia Block along the Jiangnan orogen in the early Neoproterozoic (e.g., Zhang and Zheng, 2013; Zhao, 2015) and no plate subduction had occurred inside the South China Block (Charvet, 2013; Zheng et al., 2013) until the westward subduction of Pacific slab beneath the eastern China continent in the Early Mesozoic. Therefore, subduction processes of the Cathyasia oceanic crust in the Neoproterozoic and the Pacific oceanic crust in the Mesozoic are the two possible causes for the crustal metasomatism.

The majority of previous studies hypothesized that the metasomatism was caused by the westward subduction of Pacific slab in the Mesozoic (Wang et al., 2013 and references therein). This hypothesis was based on the observation that the eastern edge of China continent is presently located above the western Pacific subduction zone, looking like an Andean-type continental margin. However, so far there is no solid petrological evidence for the Mesozoic occurrence of Andean-type continental arc andesites along this coastal region (Zheng et al., 2013), making the hypothesis of western Pacific subduction questionable. Furthermore, the MLYV region is a NEE-trend tectonic belt in the northern part of the 
Jiangnan orogen adjacent to the Yangtze Craton (Fig. 1), with quite long and variable distances away from the present trench that marks the westward subduction of Pacific plate (Fig. 1).

Alternatively, it is argued that Neoproterozoic subduction of the Cathaysia oceanic crust beneath the Yangtze Craton would result in the crustal metasomatism (e.g., Tang et al., 2012; Chen et al., 2014). This argument has gained the support from a comparison in the whole-rock two-stage Nd model ages and zircon two-stage Hf model ages between the MLYV volcanics and the Neoproterozic arc-related magmatic rocks in the Jiangnan orogen (Tang et al., 2012; Chen et al., 2014). As discussed above, the MLYV is the northern part of the Jiangnan orogen that was a continental margin arc due to subduction of the Cathaysia oceanic slab beneath the Yangtze Craton in the Neoproterozoic (Zheng et al., 2013; Zhao, 2015). In this regard, there is a long time interval between the crustal metasomatism in the Neoproterozoic and the andesitic magmatism in the Mesozoic, making the andesites of Mesozoic age in the MLYV as the product of postsubduction magmatism. As such, those metasomatites would be stored in the Jiangnan orogenic lithosphere mantle for a long time before the postsubduction magmatism. While the generation of mantle metasomatites is caused by the fossil oceanic subduction-related orogeny in the Neoproterozoic, partial melting of the metasomatites for anseditic magmatism took place in the Mesozoic with an anorogenic setting.

The above two hypotheses cannot be easily discriminated from the geochemical features of these mafic volcanics alone because adding of metasediment-derived melts to the mantle sources would inevitably lead to arc-like trace element features and variable radiogenic isotope compositions for the resulted rocks, no matter when the metasomatic event took place. In this regard, the Hf-Nd model ages for these rocks are not diagnostic index to discriminate these two hypotheses since the old Hf-Nd model ages (Tables S3 and Fig. 9) could be generated either by the old metasomatic event (the Neoproterozoic) with the juvenile signature or the young metasomatic event (the Mesozoic) with the ancient signature in the metasomatic agent. Fortunately, the Mesozoic mafic magmatism is prominent not only in the MLYV but also elsewhere in South China (e.g., Zhou and Li, 2000; Zhou et al., 2006; Li and Li, 2007; Wang et al., 2013; Niu et al., 2015). More importantly, the contemporary mafic magmatism also took place in the adjacent Dabie orogen (Zhao et al., 2013 and references therein). Given the close temporal and spatial associations between these mafic igneous rocks, if the Pacific oceanic crust-derived material could be incorporated into the mantle sources of andesites in the MLYV, they would be also incorporated into the mantle sources of mafic igneous rocks in the Dabie orogen. In this case, comparable $\mathrm{Sr}-\mathrm{Nd}$ isotope compositions are 
expected to occur in the contemporaneous mafic igneous rocks between the MLYV and the

970 Dabie orogen after correction for potential crustal contamination, because 971 metasediment-derived melts would dominate the $\mathrm{Sr}-\mathrm{Nd}-\mathrm{Pb}$ isotope compositions of mantle sources and their derivative igneous rocks. On the other hand, if the geochemical composition of maifc volcanics in the MLYV is dominated by metasediment-derived melts originated from the Neoproterozoic subducted Cathaysia oceanic crust, their Sr-Nd isotope compositions are distinct from those of the mafic igneous rocks in the Dabie orogen, because such a subduction event has no influence on the mantle sources of Mesozoic mafic igneous rocks in the Dabie orogen. Therefore, a comparison in the mafic igneous rocks between the MLYV and the Dabie orogen can shed light on the role of Pacific subduction in the petrogenesis of mafic volcanics in the MLYV.

Bearing this in mind, we have compiled the $\mathrm{Sr}-\mathrm{Nd}$ isotope compositions of Mesozoic

981

982

983

984

985

986

987

988

989

990

991

992

993

994

995

996

997

998 mafic igneous rocks from these two regions. Previous studies have concluded that the crustal contamination did not exert significant influence on the $\mathrm{Sr}-\mathrm{Nd}$ isotope compositions of either the Late Mesozoic mafic volcanics in the MLYV (e.g., Wang et al., 2006; Yan et al., 2009; Tang et al., 2012, 2013; Chen et al., 2014; this study) or the Late Mesozoic mafic igneous rocks in the Dabie orogen (Zhao et al., 2013 and references therein, Dai et al., 2014, 2015). Therefore, these mafic igneous rocks can be used to approximate their mantle source compositions. Surprisingly, these rocks exhibit distinct $\mathrm{Sr}-\mathrm{Nd}$ isotope compositions with rare overlap (Fig. 7a). The mafic igneous rocks from the Dabie orogen exhibit much more enrichment of Sr-Nd isotopes than those from the MLYV. Such a difference demonstrates that although Late Mesozoic magmatic events in the both MLYV and Dabie orogen would be geodynamically related to the subduction of Pacific slab beneath the eastern China continent (e.g., Tang et al., 2013; Zhao et al., 2013; Chen et al., 2014), the geochemical compositions of mafic igneous rocks are dominated by the compositions of local mantle sources; there is no recognizable contribution from the subducted Pacific crust to the Mesozoic magmatism in both the Dabie orogen and the MLYV. Therefore, the hypothesis of western Pacific subduction does not stand under scrutiny and we conclude that the mantle sources of the Ningwu andesites and the other mafic igneous rocks in the MLYV were primarily generated by reaction of the metasediment-derived melts with the mantle wedge peridotite during subduction of the Cathaysia oceanic slab in the Neoproterozoic. In addition, the mantle wedge above the subducted Cathaysia oceanic slab would be of asthenopsheric origin rather than cratonic origin in view of the less enriched Nd-Hf isotope compositions for the MLYV andesites than the Dabie mafic igneous rocks (Fig. 7a). Thus, the Jiangnan orogen was a 
marginal arc that was accreted to the Yangtze Craton in the Neoproterozoic. On the other hand, it is the westward subduction of the Pacific slab beneath the eastern China continent in the Mesozoic that would have caused the extension of continental lithosphere in eastern China, which serves as the geodynamic mechanism for the contemporaneous magmatism in this vast region (e.g., Zhao et al., 2013). This interpretation is also consistent with the observation that so far Mesozoic juvenile crust that is typically present in Andean-type continental margins has not been found in the MLYV as well as in the entire South China (Wang et al., 2013).

\subsection{Petrogenesis of Mesozoic andesitic rocks}

The Late Mesozoic magmatism in the MLYV was usually considered as anorogenic because it cannot be directly linked to either subduction- or collision-related orogeny in this tectonic belt at that time. Regional lithospheric extension has been assumed as its geodynamic mechanism. This is witnessed by the occurrence of coeval A-type granites and the development of extensional basins and metamorphic core complexes in this period (e.g., Li et al., 2000; Wang et al., 2006; Zhu et al., 2010). On the other hand, the Late Mesozoic magmatism may be triggered by tectonic events such as orogenic lithospheric delamination and subsequent upwelling of the asthenospheric mantle, which can yield the appropriate P-T conditions for partial melting of the fertile metasomatites in the SCLM above fossil subduction zones (e.g., Zhao et al., 2013 and references therein; Chen et al., 2014; Dai et al., 2014, 2015). In either case, the westward subduction of the Pacific slab beneath the eastern China continent during the Mesozoic would have served as the geodynamic mechanism for the anorogenic magmatism (e.g., Wu et al., 2005; Li and Li, 2007; Sun et al., 2007; Li et al., 2013; Zhao et al., 2013). Due to their fertile and enriched properties, the metasomatites in the SCLM wedge are susceptible to partial melting in response to the lithospheric extension, giving rise to andesitic to basaltic magmatism. The more fertile the mantle source is, the earlier it starts to melting (Hirschmann and Stolper, 1996; Lambart et al., 2009).

It is worth noting that Group II andesites from the Ningwu basin, together with the alkali-rich andesites from the Luzong basin, are the least enriched volcanics among the all contemporaneous mafic volcanics in the MLYV (Fig. 7). The alkali-rich rocks in the Luzong basin were previously interpreted by Chen et al. (2014) as crystallization from relatively less enriched mafic melts that were originated from less enriched mantle sources than those of the other cogenetic volcanics in the same basin. The geochemical similarity between these mafic volcanics from the different basins cannot be coincidence. Since the mafic volcanism in most extensional rift basins in the MLYV synchronously disappear after the latest stage of alkaline 
1037

1038

1039

1040

1041

1042

1043

1044

1045

1046

1047

1048

1049

1050

1051

1052

1053

1054

1055

1056

1057

1058

1059

1060

1061

1062

1063

1064

1065

1066

1067

1068

1069

magmatism (e.g., Wang et al., 2006; Xie et al., 2011; Tang et al., 2013; Chen et al., 2014), this stage of magmatism may mark exhausting of the fertile mantle sources in the SCLM.

In view of the above observations and interpretations, petrogenesis of the andesites in the MLYV can be accounted for by the SARSH model of Chen et al. (2014) in the following five steps (Fig. 14). (1) Subduction of the fossil oceanic crust beneath the continental margin in the Early Neoproterozoic. (2) Anatexis of the subducting oceanic crust at the slab-mantle interface in the fossil oceanic subduction channel. (3) Reaction of the metasediment-derived melts with the overlying mantle wedge peridotite, generating the fertile and enriched but highly heterogeneous metasomatites (Fig. 14a). (4) Storage of the metasomatites in the mantle wedge for several hundreds of millions of years (Fig. 14b). (5) Heating of the metasomatites for partial melting due to the westward subduction of Pacific plate in the Mesozoic, giving rise to the mafic volcanics. The more fertile and enriched metasomatites would be preferentially melted to produce the early stage of andesites (Fig. 14c), whereas the less fertile and enriched metasomatites would be partially melted later on to produce the late stage of andesites (Fig. 14d), which would have finally consumed the fertile and enriched mantle source in the lithospheric mantle beneath the MLYV and therefore led to the termination of mafic magmatism in the MLYV.

$<$ Figure 14>

The above five steps can be outlined as two-stage processes, with the first stage of subduction-anatexis-reaction and the second stage of storage-heating. While the other four steps are well acknowledge in the petrogenesis of modern arc volcanics, the storage in the forth step is a new concept for arc magmatism in both modern and ancient arc settings. The storage duration is short for active arc magmatism but long for fossil arc magmatism. Although the mantle sources of the MLYV andesites were generated by the Andean-type subduction of the fossil oceanic slab in the Neoproterozoic, the andesitic magmatism took place in the Mesozoic due to partial melting of the mantle metasomatites in response to the lithospheric extension at that time. While the former process is associated with the subduction-related tectonism in the first stage, the latter process occurred in the anorogenic setting at a much later time with the storage duration of about $700 \mathrm{Myr}$.

\section{Implications for the origin of continental arc andesites}

The petrogenesis of the Ningwu andesites further emphasizes the importance of subducted sediments in generating the mantle sources of contimemtal arc andesites. This has 
1070

1071

1072

1073

1074

1075

1076

1077

1078

1079

1080

1081

1082

1083

1084

1085

1086

1087

1088

1089

1090

1091

1092

1093

1094

1095

1096

1097

1098

1099

1100

1101

1102

1103

been also recognized by Straub et al. (2011) in the study of andesites in the Central Mexico arc (modern active continental margin) and by Chen et al. (2014) in the study of andesites in the Luzong basin, South China (fossil active continental margin). In the both cases, it is argued that the andesitic rocks were directly originated from fertile and enriched mantle sources and the influence of crustal processes such as AFC and magma mixing on the composition of these andesites is secondary. Although modern andesites occur in active continental margins, ancient andesites are expected to occur in fossil continental margins. In either case, the generation of mantle sources for andesitic rocks is controlled by the same factors such as sediment subduction, sediment melting, and melt-peridotite interaction though there are some subtle differences in the origin of andesitic rocks between active and fossil continental margins in view of the mechanism of partial melting (slab rollback vs lithospheric extension). In this regard, studies of andesitic rocks in fossil continental margins can shed light on the petrogenesis of andesitic rocks in active continental margins.

The classic model of Taylor (1967) for andesite petrogenesis is that primary andesitic magmas were directly produced by partial melting of the subducting oceanic crust. It appears that this model is only applicable to adakites above Andean-type subduction zones (Drummond and Defant, 1990). On the other hand, it is known for experimental petrology that andesitic rocks cannot be produced by partial melting of mantle peridotite (Wyllie, 1984). The common lithology of the asthenopsheric mantle is lherzolite that is composed of $>50 \%$ olivine plus $<50 \%$ clinopyroxene and orthopyroxene, and the common product of its partial melting is mid-ocean ridge basalts (MORB) with low $\mathrm{SiO}_{2}$ contents of $<52 \%$, high $\mathrm{MgO}$ contents of $>8 \%$ and thus high Mg\# values of >60 (Green, 2015; Green and Falloon, 2015). Although primary high-Mg andesitic melts can be produced either by hydration melting of the mantle wedge peridotite or by dehydration melting of the ultramafic metsomatite that was generated by reaction of the mantle wedge peridotite with adakatic melts derived from direct melting of the subducting oceanic crust, the both mechanisms fail to produce mafic melts with composition matching the natural high-Mg andesites (Kelemen et al., 2014; Mitchell and Grove, 2015). In addition, the high-Mg andesites in equilibrium with olivine and pyroxene in mantle peridotite are volumetrically minor compared to high-Mg basalts (e.g., Tatsumi, 2006).

Nevertheless, high-Mg andesites are closely associated in time and space with arc basalts, showing geochemical continuity between them (Gill, 1981). In this regard, the proportion of primary andesites among arc volcanic rocks and their sources in the mantle wedge may be underestimated. This is because: (1) the fertile lithology (e.g., silica-excess pyroxenite) that can serve as the mantle source of andesitic magmas has significantly a lower solidus 
temperature than the normal peridotite, making it susceptible to partial melting (e.g., Hirschmann and Stolper, 1996; Sobolev et al., 2005, 2007; Lambart et al., 2009) and thus hard to be directly observed in mantle xenoliths and massifs; (2) the primary andesites are not necessary to have high $\mathrm{MgO}$ contents and Mg\# values (Sobolev et al., 2007) and thus hard to discriminate them from the differentiative product of basaltic magmas; (3) the temporal and spatial associations between arc basalts and low-Mg andesites as well as their geochemical continuity may be controlled by the composition of their mantle sources, which were generated by metasomatism with the same agent but different amounts or with different agents from the subducted oceanic crust. These heterogeneous mantle sources would simultaneously undergo partial melting, giving rise to the observed temporal, spatial and compositional associations between basaltic and andesitic rocks.

It has been inferred from field-based geochemical and laboratoty experimental studies that the olivine-poor ultramafic lithology contributes significantly to the origin of mafic igneous rocks in both interplate and intraplate settings (e.g., Sobolve et al., 2005, 2007; Pilet et al., 2008; Zhang et al., 2009; Xu et al., 2012; Lambart et al., 2013; Dai et al., 2014, 2015). Because of the remarkable difference in lithology between olivine-poor metasomatites and olivine-rich peridotites, it is necessary to take into account the lithochemical constraints on the composition of mafic melts. Although so far only one experimental study has been made on the partial melting of a model hybrid pyroxenite that is an analogue to the product of melt-peridotite reaction, primary andesitic melts with $\mathrm{SiO}_{2}>60 \%, \mathrm{MgO}<5 \%$ and $\mathrm{Mg} \#<55$ were indeed produced by Sobolev et al. (2007). In addition, recent studies of experimental petrology and geodynamic modeling suggest that the partial melting of subducting metasediments at subarc depths may be the rule rather than the exception in most oceanic subduction zones (Hermann and Spandler 2008; Klimm et al. 2008; Plank et al. 2009; Behn et al. 2011). This yields considerable amounts of hydrous felsic melts with strong enrichment of melt-mobile incompatible trace elements and their pertinent radiogenic isotopes. These melts would inevitably react with the mantle wedge peridotite to generate the fertile and enriched metasomatites, with much more amounts of pyroxene, phlogopite and amphibole but less amount of olivine than the normal peridotites (Rapp et al., 1999; Sobolev et al., 2005, 2007; Castro et al., 2008, 2010, 2013).

The metasomatic reaction between the mantle wedge peridotite and the metasediment-derived hydrous felsic melts is expected to take place more intensively beneath the continental subarc mantle than the oceanic subarc mantle given that larger amounts of the terrigenous sediment were carried to subarc depths by subduction beneath continental margins 
(e.g., von Huene and Scholl, 1991; Clift and Vannucchi, 2004; Scholl and von Huene, 2009; Planck, 2014). As a consequence, a larger amount of the metasediment component is incorporated into the less ultramafic metasomatites that would be more favorably generated in the oceanic-continental subduction zones than in oceanic-oceanic subduction zones. Furthermore, the much more extensive occurrence of andesitic rocks in continental arcs than in oceanic arcs (Gill, 1981) may indicate a dominant role of the melt-metasomatized mantle melting instead of the fluid-metasomatized mantle melting in the continental arc magmatism (Zheng et al., 2015).

\section{Conclusions}

The Ningwu volcanics are primarily composed of shoshonitic andesitic rocks with enriched geochemical characteristics similar to continental arc andesites. They can be categorized into two groups in view of their distinct geochemical features. An integrated geochemical study demonstrates that although such processes as crystal fractionation and magma mixing were operated during andesitic magmatism, they have secondary influences on the lithochemistry of andesitic composition in the Ningwu volcanics. It is particularly so for Group I andesites, which were produced by partial melting of phlogopite-bearing mantle sources that are less ultramafic in lithochemistry than normal peridotite. The distinct geochemical features between the two groups of andesites are attribued to the combined effects of source heterogeneity and different degrees of partial melting. Such sources were generated by reaction of the mantle wedge peridotite with hydrous felsic melts derived from partial melting of subducting terrigenius sediment. Therefore, the present study lends support to the SARSH model of Chen et al. (2014) for the petrogenesis of andesitic rocks in the MLYV. The metasomatic reaction that resulted in the generation of such fertile and enriched mantle sources would have taken place during the subduction of the Chathyasia oceanic crust beneath the Yangtze Craton in the Neoproterozoic. Nevertheless, the mantle sources underwent partial melting in the Late Mesozoic in response to the extension of continental lithosphere due to the westward subduction of Pacifc slab beneath the eastern China continent. No material contribution from the Mesozoic subducted Pacific oceanic slab has been positively identified in the Ningwu andesites. Therefore, the Late Mesozoic mafic magmatism in the Middle-Lower Yangtze Valley is essentially caused by reactivation of the fertile and enriched mantle sources in the northern part of the Jiangnan orogen adjacent to the Yangtze Craton. It is emphasized that significant incorporation of metasediment-derived hydrous felsic 
1171 melts into the mantle wedge and the subsequent melt-peridotite reaction at the slab-mantle 1172 interface in the oceanic subduction channel is the key to the origin of andesitic rocks.

1173

\section{Acknowledgments}

1175 This study was supported by funds from the Chinese Ministry of Science and 1176 Technology (2015CB856100) and the National Science Foundation of China (41125012).

1177 Thanks are due to Peng Gao, Chenghu Tang and Haiou Gu for their assistance with field work, 1178 to Wei Rong, Yusheng Zhu, Yuanxin Xiang, Yueheng Yang and Jinhui Yang for their 1179 assistance with Sr-Nd-Hf isotope analyses, to Xianhua Li and Qiuli Li for their assistance 1180 with zircon $\mathrm{O}$ isotope analyses and to Yueheng Yang for his assistance with zircon Hf isotope 1181 analyses. YFZ thanks Yuejun Wang and Guochun Zhao for simulating discussion on the 1182 tectonic range of the Jiangnan orogen. Comments by Sun-Lin Chung, Yanjie Tang and one 1183 anonymous reviewer greatly helped the improvement of the presentation. 
Annen, C., Blundy, J. D., Sparks, R. S. J., 2006. The genesis of intermediate and silicic magmas in deep crustal hot zones. Journal of Petrology 47, 505-539.

Annen, C., Sparks, R. S. J., 2002. Effects of repetitive emplacement of basaltic intrusions on thermal evolution and melt generation in the crust. Earth and Planetary Science Letters 203, 937-955.

Baker, M., Grove, T. L., Price, R., 1994. Primitive basalts and andesites from Magnetite. Shasta region, N. California: products of varying melt fraction and water content. Contributions to Mineralogy and Petrology 118, 111-129.

Behn, M.D., Kelemen, P.B., Hirth, G., Hacker, B.R., Massonne, H.-J., 2011. Diapirs as the source of the sediment signature in arc lavas. Nature Geoscience 4, 641-646.

Bindeman, I., 2008. Oxygen isotopes in mantle and crustal magmas as revealed by single crystal analysis. Reviews in Mineralogy and Geochemistry 69, 445-478.

Blundy, J., Wood, B., 2003. Partitioning of trace elements between crystals and melts. Earth and Planetary Science Letters 210, 383-397.

Bouvier, A., Vervoort, J.D., Patchett, P.J., 2008. The Lu-Hf and Sm-Nd isotopic composition of CHUR: constraints from unequilibrated chondrites and implications for the bulk composition of terrestrial planets. Earth and Planetary Science Letters 273, 48-57.

Bowen, N. L., 1928. Evolution of Igneous Rocks. Princeton University Press, Princeton NJ.

Castro, A., Gerya, T.V., 2008. Magmatic implications of mantle wedge plumes: Experimental study. Lithos 103, 138-148.

Castro, A., Gerya, T.V., García-Casco, A., Fernández, C., Díaz Alvarado, J., Moreno-Ventas, I., Loew, I., 2010. Melting relations of MORB-sediment melanges in underplated mantle wedge plumes: Implications for the origin of Cordilleran-type batholiths. Journal of Petrology 51, 1267-1295.

Castro, A., Vogt, K., Gerya, T.V., 2013. Generation of new continental crust by sublithospheric silicic-magma relamination in arcs: A test of Taylor's andesite model. Gondwana Research 23, 1554-1566.

Charvet, J., 2013. The Neoproterozoic-First Paleozoic tectonic evolution of the South China Block: An overview. Journal of Asian Earth Sciences 74, 198-209.

Chauvel, C., Lewin, E., Carpentier, M., Arndt, N. T., Marini, J. C., 2007. Role of recycled oceanic basalt and sediment in generating the $\mathrm{Hf}-\mathrm{Nd}$ mantle array. Nature Geoscience 1, 64-67. 
Chayes, F., 1963. Relative abundance of intermediate members of the oceanic basalt-trachyte association. Journal of Geophysical Research 68, 1519-1534.

Chen, J.F., Jahn, B.-m., 1998. Crustal evolution of southeastern China: Nd and Sr isotopic evidence. Tectonophysics 284, 101-133.

Chen, J.F., Yan, J., Xie, Z., Xu, X., Xing, F., 2001. Nd and Sr isotopic compositions of igneous rocks from the Lower Yangtze region in eastern China: constraints on sources. Physics and Chemistry of the Earth (A) 26, 719-731.

Chen, L., Zhao, Z. F., Zheng, Y. F. 2014. Origin of andesitic rocks: geochemical constraints from Mesozoic volcanics in the Luzong basin, South China. Lithos 190, 220-239.

Choi, H.O., Choi, S.H., Lee, D.C., Kang, H.C., 2013. Geochemical evolution of basaltic volcanism within the tertiary basins of southeastern Korea and the opening of the East Sea (Sea of Japan). Journal of Volcanology and Geothermal Research 249, 109-122.

Clift, P.D., Vannucchi, P., 2004. Controls on tectonic accretion versus erosion in subduction zones: Implications for the origin and recycling of the continental crust. Review of Geophysics 42, RG2001, 2003RG000127.

Conceição, R.V., Green, D.H., 2004. Derivation of potassic (shoshonitic) magmas by decompression melting of phlogopite + pargasite lherzolite. Lithos 72, 209-229.

Condamine, P., Médard, E., 2014. Experimental melting of phlogopite-bearing mantle at 1 GPa: Implications for potassic magmatism. Earth and Planetary Science Letters 397, 80-92.

Dai, L.-Q., Zhao, Z.-F., Zheng, Y.-F., Zhang, J., 2012. The nature of orogenic lithospheric mantle: geochemical constraints from postcollisional mafic-ultramafic rocks in the Dabie orogen. Chemical Geology 334, 99-121.

Dai, L.-Q., Zhao, Z.-F., Zheng, Y.-F., 2014. Geochemical insights into the role of metasomatic hornblendite in generating alkali basalts. Geochemistry, Geophysics, Geosystems 15, 3762-3779.

Dai, L.-Q., Zhao, Z.-F., Zheng, Y.-F., 2015. Tectonic development from oceanic subduction to continental collision: Geochemical evidence from postcollisional mafic rocks in the Hong'an-Dabie orogens. Gondwana Research 27, 1236-1254.

DePaolo, D. J., 1981. Trace element and isotopic effects of combined wallrock assimilation and fractional crystallization. Earth and planetary Science Letters 53, 189-202.

DePaolo, D.J., 1988. Neodymium Isotope Geochemistry: An Introduction. Springer-Verlag, New York, 187 p.

Drummond, M.S., Defant, M.J., 1990. A model for trondjhemite-tonalite-dacite genesis and 
crustal growth via slab melting. Journal of Geophysical Research 95, 21503-21521.

Ducea, M. N., Saleeby, J. B., Bergantz, G., 2015. The Architecture, Chemistry, and Evolution of Continental Magmatic Arcs. Annual Review of Earth and Planetary Sciences 43, 10-1.

Eiler, J., Crawford, A., Elliott, T., Farley, K.A., Valley, J.W., Stolper, E.M., 2000. Oxygen isotope geochemistry of oceanic arc lavas. Journal of Petrology 41, 229-256.

Elliott, T., Plank, T., Zindler, A., White, W., Bourdon, B., 1997. Element transport from slab to volcanic front at the Mariana arc. Journal of Geophysical Research: Solid Earth (1978-2012) 102(B7), 14991-15019.

Elliott, T., 2003. Tracers of the slab. In: Eiler, J., (ed.). Inside the Subduction Factory. American Geophysical Union Geophysical Monograph 138, 23-45.

Ernst, W.G., Tsujimori, T., Zhang, R.Y., Liou, J.G., 2007. Permo-Triassic collision, subduction-zone metamorphism, and tectonic exhumation along the East Asian continental margin. Annual Review of Earth and Planetary Sciences 35, 73-110.

Foley, S., 1992a. Petrological characterization of the source components of potassic magmas: geochemical and experimental constraints. Lithos 28, 187-204.

Foley, S., 1992b. Vein-plus-wall-rock melting mechanisms in the lithosphere and the origin of potassic alkaline magmas. Lithos 28, 435-453.

Foley, S., Peccerillo, A., 1992. Potassic and ultrapotassic magmas and their origin. Lithos 28, 181-185.

Furman, T., Graham, D., 1999. Erosion of lithospheric mantle beneath the East African Rift system: geochemical evidence from the Kivu volcanic province. Developments in Geotectonics 24, 237-262.

Gallet, S., Jahn, B.-m., Torii, M., 1996. Geochemical characterization of the Luochuan loess-Paleosol sequence, China, and Paleoclimatic implications. Chemical Geology 133, 67-88.

Gao, S., Ling, W.L., Qiu, Y.M., Lian, Z., Hartmann, G., Simon, K., 1999. Contrasting geochemical and Sm-Nd isotopic compositions of Archean metasediments from the Kongling high-grade terrain of the Yangtze craton: evidence for Cratonic evolution and redistribution of REE during crustal anatexis. Geochimica et Cosmochimica Acta 63, 2071-2088.

Gill, J.B., 1981. Orogenic Andesites and Plate Tectonics. Springer-Verlag, New York, 390 p.

Gill, R., 2010. Igneous Rocks and Processes: A Practical Guide. Wiley-Blackwell, Malaysia, $428 \mathrm{p}$.

Green, D.H., 2015. Experimental petrology of peridotites, including effects of water and 
carbon on melting in the Earth's upper mantle. Physics and Chemistry of Minerals 42, 95-122.

Green, D.H., Falloon, T.J., 2015. Mantle-derived magmas: intraplate, hot-spots and mid-ocean ridges. Science Bulletin 60, 1873-1900.

Griffin, W.L., Pearson, N.J., Elusive, E., Jackson, S.E., van Achtenberg, E., O'Reilly, S.Y., She, S.R., 2000. The Hf isotope composition of carbonic mantle: LAM-MC-ICPMS analysis of zircon megacrysts in kimberlites. Geochimica et Cosmochimica Acta 64, 133-147.

Griffin, W.L., Wang, X., Jackson, S.E., Pearson, N.J., O'Reilly, S.Y., Xu, X., Zhou, X., 2002. Zircon chemistry and magma mixing, SE China: In-situ analysis of Hf isotopes, Tonglu and Pingtan igneous complexes. Lithos 61, 237-269.

Grove, T.L., Till, C.B., Krawczynski, M.J., 2012. The role of $\mathrm{H}_{2} \mathrm{O}$ in subduction zone magmatism. Annual Review of Earth and Planetary Sciences 40, 413-439.

Gualda, G. A., Ghiorso, M. S., 2015. MELTS_Excel: A Microsoft Excel-based MELTS interface for research and teaching of magma properties and evolution. Geochemistry, Geophysics, Geosystems 16, 315-324.

Guo, L.Z., Shi, Y.S., Ma, R.S., Lu, H.F., 1985. Plate movement and crustal evolution of the Jiangnan Proterozoic mobile belt, Southeast China. Earth Science (the Journal of the association for the Geological Collabration in Japan) 39, 156-166.

He, C.S., Dong, S.W., Santosh, M., Chen, X.H., 2013. Seismic evidence for a geosuture between the Yangtze and Cathaysia Blocks, South China. Scientific Reports 3, 2200; doi:10.1038/srep02200.

Hermann, J., Spandler, C. J., 2008. Sediment melts at sub-arc depths: an experimental study. Journal of Petrology 49, 717-740.

Hildreth, W., Moorbath, S., 1988. Crustal contributions to arc magmatism in the Andes of central Chile. Contributions to Mineralogy and Petrology 98, 455-489.

Hirschmann, M. M., Stolper, E. M., 1996. A possible role for garnet pyroxenite in the origin of the "garnet signature" in MORB. Contributions to Mineralogy and Petrology 124, 185-208.

Hoefs, J., 2009. Variations of Stable Isotope Ratios in Nature. Stable Isotope Geochemistry, 93-227.

Hofmann, A.W., 1997. Mantle geochemistry: the message from oceanic volcanism. Nature 85, 219-229.

Hou, K.J., Yuan, S.D., 2010. Zircon U-Pb age and Hf isotopic composition of the volcanic and 
sub-volcanic rocks in the Ningwu basin and their geological implications. Acta Petrologica Sinica (in Chinese with English abstract) 26, 888-902.

Huang, F., Li, S.G., Dong, F., Li, Q.L., Chen, F.K., Wang, Y. Yang, W., 2007. Recycling of deeply subducted continental crust in the Dabie Mountains, central China. Lithos 96, 151-169.

Huppert, H.E., Sparks, R.S.J., 1988. The generation of granitic magmas by intrusion of basalt into continental crust. Journal of Petrology 29, 599-624.

Hyndman, R.D., Peacock, S.M., 2003. Serpentinization of the forearc mantle. Earth and Planetary Science Letters 212, 417-432.

lizuka, T., Hirata, T., 2005. Improvements of precision and accuracy in situ Hf isotope microanalysis of zircon using the laser ablation-MC-ICPMS technique. Chemical Geology 220, 121-137.

Jahn, B.-m., Condie, K.C., 1995. Evolution of the Kaapvaal Craton as viewed from geochemical and Sm-Nd isotopic analyses of intracratonic pelites. Geochimica et Cosmochimica Acta 59, 2239-2258.

Jahn, B.-m., Wu, F.Y., Lo, C.H., Tsai, C.H., 1999. Crust-mantle interaction induced by deep subduction of the continental crust: geochemical and $\mathrm{Sr}-\mathrm{Nd}$ isotopic evidence from post-collisional matic-ultramatlc intrusions of the north Dabie complex, central China. Chemical Geology 157, 119-146.

Kelemen, P.B., Yogodzinski, G.M., School, D.W., 2003. Along-strike variation in the Aleutian island arc: Genesis of high $\mathrm{Mg \#}$ andesite and implications for continental crust. Geophysical Monograph Series 138, 223-276.

Kelemen, P.B., Hanghoj, K., Greene, A.R., 2014. One view of the geochemistry of subduction-resecondd magmatic arcs, with an emphasis on primitive andesite and lower crust. Treatise on Geochemistry 4, 746-805.

Kessel, R., Schmidt, M.W., Ulmer, P., Pettke, T., 2005. Trace element signature of subduction-zone fluids, melts and supercritical liquids at 120-180 km depth. Nature 437, 724-727.

Klimm, K., Blundy, J. D., Green, T. H., 2008. Trace element partitioning and accessory phase saturation during H2O-saturated melting of basalt with implications for subduction zone chemical fluxes. Journal of Petrology 49, 523-553.

Kogiso T., Tatsumi Y., and Nakano S., 1997. Trace element transport during dehydration processes in the subducted oceanic crust. 1: Experiments and implications for the origin of ocean island basalts. Earth Planetary Science Letters 148, 193-205. 
Lambart, S., Laporte, D., Schiano, P., 2009. An experimental study of pyroxenite partial melts at 1 and 1.5 GPa: Implications for the major-element composition of Mid-Ocean Ridge Basalts. Earth and Planetary Science Letters 288, 335-347.

Lambart, S., Laporte, D., Schiano, P., 2013. Markers of the pyroxenite contribution in the major-element compositions of oceanic basalts: Review of the experimental constraints. Lithos 160, 14-36.

LaTourrette, T., Hervig, R. L., Holloway, J. R., 1995. Trace element partitioning between amphibole, phlogopite, and basanite melt. Earth and Planetary Science Letters 135, 13-30.

Le Maitre, R.W., 2002. Igneous Rocks: A Classification and Glossary of Terms. Second Edition, Cambridge University Press, Cambridge.

Lee, C.T.A., Bachmann, O., 2014a. How important is the role of crystal fractionation in making intermediate magmas? Insights from $\mathrm{Zr}$ and $\mathrm{P}$ systematics. Earth and Planetary Science Letters 393, 266-274.

Lee, C.T.A., Lee, T.C., Wu, C.T., 2014b. Modeling the compositional evolution of recharging, evacuating, and fractionating (REFC) magma chambers: Implications for differentiation of arc magmas. Geochimica et Cosmochimica Acta 143, 8-22.

Li, Z.-X., 1994. Collision between the North and South China blocks: A crustal-detachment model for suturing the region east of the Tanlu fault. Geology 22, 739-742.

Li, Z.X., Li, X.H., 2007. Formation of the 1300-km-wide intracontinental orogen and postorogenic magmatic province in Mesozoic South China: a flat-slab subduction model. Geology 35, 179-182.

Li, H., Zhang, H., Ling, M.X., Wang, F.Y., Ding, X., Zhou, J.B., Yang, X.Y., Tu, X.L., Sun, W.D., 2011. Geochemical and zircon U-Pb study of the Huangmeijian A-type granite: implications for geological evolution of the Lower Yangtze River belt. International Geology Review 53, 499-525.

Li, X.H., 2000. Cretaceous magmatism and lithospheric extension in southeast China. Journal of Asian Earth Sciences 18, 293- 305.

Li, X.H., Gui, X.T., 1991. Source rock of the Caledonian-age granitoid rocks in Wanyangshan, southeast China. Science in China (B) 21, 533-540 (in Chinese).

Li, X.H., Li, W.X., Li, Z.X., Lo, C.H., Wang, J., Ye, M.F., Yang, Y.H., 2009. Amalgamation between the Yangtze and Cathaysia Blocks in South China: constraints from SHRIMP $\mathrm{U}-\mathrm{Pb}$ zircon ages, geochemistry and Nd-Hf isotopes of the Shuangxiwu volcanic rocks. Precambrian Research 174, 117-128. 
Li, X.-H., Li, W.-X., Li, Q.-L., Wang, X.-C., Liu, Y., Yang, Y.-H., 2010a. Petrogenesis and tectonic significance of the 850 Ma Gangbian alkaline complex in South China: evidence from in situ zircon $\mathrm{U}-\mathrm{Pb}$ dating, $\mathrm{Hf}-\mathrm{O}$ isotopes and whole-rock geochemistry. Lithos $114,1-15$.

Li, X.-H., Long, W.-G., Li, Q.-L., Liu, Y., Zheng, Y.-F., Yang, Y.-H., Chamberlain, K.R., Wan, D.-F., Guo, C.-H., Wang, X.-C., Tao, H., 2010b. Penglai zircon megacrysts: a potential new working reference material for microbeam determination of $\mathrm{Hf}-\mathrm{O}$ isotopes and U-Pb age. Geostandards Geoanalytical Research 34, 117-134.

Li, X.-H., Li, Z.-X., Li, W.-X., Wang, X.-C., Gao, Y.Y.., 2013. Revisiting the "C-type adakites" of the Lower Yangtze River Belt, central eastern China: In-situ zircon Hf-O isotope and geochemical constraints. Chemical Geology 345, 1-15.

Liu, S.A., Li, S.G., He, Y.S., Huang, F., 2010. Geochemical contrasts between first Cretaceous ore-bearing and ore-barren high-Mg adakites in central-eastern China: implications for petrogenesis and $\mathrm{Cu}-\mathrm{Au}$ mineralization. Geochimica et Cosmochimica Acta 74, 7160-7178.

Ludwig, K.R., 2001. Users Manual for Isoplot/Ex (re 2.49): A Geochronological Toolkit for Microsoft Excel. Berkeley Geochronology Center, Special Publication, No.1a, 55 p

Lugmair, G. W., K. Marti., 1978. Lunar initial ${ }^{143} \mathrm{Nd} /{ }^{144} \mathrm{Nd}$ : Differential evolution of the lunar crust and mantle, Earth and Planetary Science Letters 39, 349-357.

Ma, C., Ehlers, C., Xu, C., Li, Z., Yang, K., 2000. The roots of the Dabieshan ultrahigh-pressure metamorphic terrane: constraints from geochemistry and $\mathrm{Nd}-\mathrm{Sr}$ isotope systematics. Precambrian Research 102, 279-301.

Mao, J.W.,Wang, Y.T., Lehmann, B., Yu, J.J., Du, A.D., Mei, Y.X., Li, Y.F., Zang, W.S., Stein, H.J., Zhou, T.F., 2006. Molybdenite Re-Os and albite ${ }^{40} \mathrm{Ar} /{ }^{39} \mathrm{Ar}$ dating of $\mathrm{Cu}-\mathrm{Au}-\mathrm{Mo}$ and magnetite porphyry systems in the Changjiang valley and metallogenic implications. Ore Geology Reviews 29, 307-324.

Mao, J.W., Pirajno, F., Cook, N., 2011. Mesozoic metallogeny in East China and corresponding geodynamic settings - An introduction to the special issue. Ore Geology Reviews 43, 1-7.

Mao, J.W., Cheng, Y.B., Chen, M.H., Franco, P., 2013. Major types and time-space distribution of Mesozoic ore deposits in South China and their geodynamic settings. Mineralium Deposita 48, 267-294.

McCulloch, M., Gamble, J., 1991. Geochemical and geodynamical constraints on subduction zone magmatism. Earth and Planetary Science Letters 102, 358-374. 
McDonough, W.F., Sun, S.-s., 1995. The composition of the Earth. Chemical Geology 120, 223-253.

Mitchell, A.L., Grove, T.L., 2015. Melting the hydrous, subarc mantle: the origin of primitive andesites. Contributions to Mineralogy and Petrology 170, 1-23.

Morel, M.L.A., Nebel, O., Nebel-Jacobsen, Y.J., Miller, J.S. Vroon, P.Z., 2008. Hafnium isotope characterization of the GJ-1 zircon reference material by solution and laser-ablation MC-ICPMS. Chemical Geology 255, 231-235.

Moyen, J.-F., 2009. High $\mathrm{Sr} / \mathrm{Y}$ and La/Yb ratios: the meaning of the 'adakitic signature'. Lithos 112, 556-574.

Münker, C., Weyer, S., Scherer, E., Mezger, K., 2001. Separation of high field strength elements ( $\mathrm{Nb}, \mathrm{Ta}, \mathrm{Zr}, \mathrm{Hf})$ and Lu from rock samples for MC-ICPMS measurements. Geochemistry, Geophysics, Geosystems 2 (12), doi: 10.1029/2001GC000183.

Naemura, K., Hirajima, T., Svojtka, M., 2009. The Pressure-Temperature Path and the Origin of Phlogopite in Spinel-Garnet Peridotites from the Blanský Les Massif of the Moldanubian Zone, Czech Republic. Journal of Petrology 50, 1795-1827.

Nebel, O., Scherer, E.E., Mezger, K., 2011. Evaluation of the $87 R b$ decay constant by age comparison against the U-Pb system. Earth and Planetary Science Letters 301, 1-8.

Ni, R.S., Wu, Q. C., Yue, W. Z., 1998. Mesozoic continental basin evolution and mineralization of in the Middle-Lower Yangtze River Belt. Shanghai Scientific and Technological Literature Publishing House (in Chinese) 25, 1-118.

Niu, Y., Liu, Y., Xue, Q., Shao, F., Chen, S., Duan, M., Kong, J., 2015. Exotic origin of the Chinese continental shelf: new insights into the tectonic evolution of the western Pacific and eastern China since the Mesozoic. Science Bulletin 60, 1598-1616.

Pan, Y., Dong, P., 1999. The Lower Changjiang (Yangzi/Yangtze River) metallogenic belt, east China: intrusion-and wall rock-hosted $\mathrm{Cu}-\mathrm{Fe}-\mathrm{Au}, \mathrm{Mo}, \mathrm{Zn}, \mathrm{Pb}, \mathrm{Ag}$ deposits. Ore Geology Reviews 15, 177-242.

Pilet, S., Baker, M. B., Stolper, E. M., 2008. Metasomatized lithosphere and the origin of alkaline lavas. Science 320, 916-919.

Pin, C., Zalduegui, J. S., 1997. Sequential separation of light rare-earth elements, thorium and uranium by miniaturized extraction chromatography: application to isotopic analyses of silicate rocks. Analytica Chimica Acta 339, 79-89.

Plank, T., Langmuir, C. H., 1988. An evaluation of the global variations in the major element chemistry of arc basalts. Earth and Planetary Science Letters 90, 349-370.

Plank, T., Cooper, L. B., Manning, C. E., 2009. Emerging geothermometers for estimating 
slab surface temperatures. Nature Geoscience 2, 611-615.

Plank, T., 2014. The chemical composition of subducting sediments. Treatise on Geochemistry 4, 607-629.

Rapp, R. P., Watson, E.B, 1995. Dehydration melting of metabasalt at 8-32 kbar: Implications for continental growth and crust-mantle recycling. Journal of Petrology 36, 891-931.

Rapp, R. P., Shimizu, N., Norman, M. Applegate, G., 1999. Reaction between slab-derived melts and peridotite in the mantle wedge: experimental constraints at $3.8 \mathrm{GPa}$. Chemical Geology 160, 335-256.

Rapp, R. P., Norman, M. D., Laporte, D., Yaxley, G. M., Martin, H., Foley, S. F. 2010. Continent formation in the Archean and chemical evolution of the cratonic lithosphere: melt-rock reaction experiments at 3-4 GPa and petrogenesis of Archean Mg-diorites (sanukitoids). Journal of Petrology 51, 1237-1266.

Reichardt, H. Weinberg, R. F. 2012. Hornblende chemistry in meta- and diatexites and its retention in the source of leucogranites: an example from the Karakoram Shear Zone, NW India. Journal of Petrology 53, 1287-1318.

Rudnick, R.L., 1995. Making continental crust. Nature 378, 571-578.

Scherer, E., Munker, C., Mezger, K., 2001. Calibration of the lutetium-hafnium clock. Science 293, 683-687.

Scholl, D.W., von Huene, R., 2009. Implications of estimated magmatic additions and recycling losses at the subduction zones of accretionary (non-collisional) and collisional (suturing) orogens. Geological Society Special Publication 318, 105-125.

Sekine, T., Wyllie, P.J., 1982. The system granite-peridotite-H2O at 30 kbar, with applications to hybridization in subduction zone magmatism. Contributions to Mineralogy and Petrology 81, 190-202.

Sen, C., Dunn, T., 1994. Dehydration melting of a basaltic composition amphibolite at 1.5 and 2.0 GPa: implications for the origin of adakites. Contributions to Mineralogy and Petrology 117, 394-409.

Sobolev, A.V., Hofmann, A.W., Sobolev, S.V., Nikogosian, I.K., 2005. An olivine-free mantle source of Hawaiian shield basalts. Nature 434, 590-597.

Sobolev, A.V., Hofmann, A.W., Kuzmin, D.V., Yaxley, G.M., Arndt, N.T., Chung, S.L., Teklay, M., 2007. The amount of recycled crust in sources of mantle-derived melts. Science 316(5823), 412-417.

Spandler, C. and Pirard, C., 2013. Element recycling from subducting slabs to arc crust: A review. Lithos 170-171, 208-223. 
Stacey, J.S., Kramers, J.D., 1975. Approximation of terrestrial lead isotope evolution by a two-group model. Earth and Planetary Science Letters 26, 207-221.

Stern, R. J., 2002. Subduction zones. Reviews of Geophysics 40 (4), 1012; doi:10.1029/2001RG000108.

Straub, S.M., Gomez-Tuena, A., Stuart, F.M., Zellmer, G.F., Espinasa-Perena, R., Cai, Y. Iizuka, Y., 2011. Formation of hybrid arc andesites beneath thick continental crust. Earth and Planetary Science Letters 303, 337-347.

Straub, S.M., Gómez-Tuena, A., Bindeman, I.N., Bolge, L.L., Brandl, P.A., Espinasa-Perena, R., Zellmer, G.F., 2015. Crustal recycling by subduction erosion in the central Mexican Volcanic Belt. Geochimica et Cosmochimica Acta 166, 29-52.

Sun, W.D., Ding, X., Hu, Y.-H., Li, X.-H., 2007. The golden transformation of the Cretaceous plate subduction in the west Pacific. Earth and Planetary Science Letters 262, 533-542.

Tang, J., Zheng, Y.-F., Wu, Y.-B., Gong, B., Liu, X.M., 2007. Geochronology and geochemistry of metamorphic rocks in the Jiaobei terrane: constraints on its tectonic affinity in the Sulu orogen. Precambrian Research 152, 48-82.

Tang, J., Zheng, Y.-F., Wu, Y.-B., Gong, B., Zha, X.P., Liu, X.M., 2008. Zircon U-Pb age and geochemical constraints on the tectonic affinity of the Jiaodong terrane in the Sulu orogen, China. Precambrian Research 161, 389-418.

Tang, M., Wang, X.L., Xu, X.S., Zhu, C., Cheng, T., Yu, Y., 2012. Neoproterozoic subducted materials in the generation of Mesozoic Luzong volcanic rocks: evidence from apatite geochemistry and Hf-Nd isotopic decoupling. Gondwana Research 21, 266-280.

Tang, Y.J., Zhang, H.F., Ying, J.F., Su, B.X., Li, X.H., Santosh, M., 2013. Rapid eruption of the Ningwu volcanics in eastern China: Response to Cretaceous subduction of the Pacific plate. Geochemistry, Geophysics, Geosystems 14, 1703-1721.

Tatsumi, Y., 2006. High-Mg andesites in the Setouchi volcanic belt, southwestern Japan: analogy to Archean magmatism and continental crust formation? Annual Review of Earth and Planetary Sciences 34, 467-499.

Taylor, S.R., 1967. The origin and growth of continents. Tectonophysics 4, 17-34.

Taylor, S.R., McLennan, S.M., 1985. The Continental Crust: Its Composition and Evolution. Blackwell, Oxford.

Turner, S., Arnaud, N., LIU, J., Rogers, N., Hawkesworth, C., Harris, N., Deng, W., 1996. Post-collisional shoshonitic volcanism on the Tibetan Plateau: implications for convective thinning of the lithosphere and the source of ocean island basalts. Journal of Petrology 37, 45-71. 
Valley, J.W., Kinny, P.D., Schulze, D.J., Spicuzza, M.J., 1998. Zircon megacrysts from kimberlite: oxygen isotope variability among mantle melts. Contributions to Mineralogy and Petrology 133, 1-11.

Vervoort, J.D., Patchett, P.J., Blichert-Toft, J., Albarede, F., 1999. Relationships between $\mathrm{Lu}-\mathrm{Hf}$ and $\mathrm{Sm}-\mathrm{Nd}$ isotopic systems in the global sedimentary system. Earth and Planetary Science Letters 168, 79-99.

Vervoort, J.D., Plank, T., Prytulak, J., 2011. The Hf-Nd isotopic composition of marine sediments. Geochimica et Cosmochimica Acta 75, 5903-5926.

von Huene, R., Scholl, D.W., 1991. Observations at convergent margins concerning sediment subduction, subduction erosion, and the growth of continental crust. Review of Geophysics 29, 279-316.

Wang, Y. L., Q. Zhang., Y. Wang., 2001. Geochemical characteristics of volcanic rocks from Ningwu area, and its significance. Acta Petrologica Sinica (in Chinese with English abstract) $17,565-575$.

Wang, Y.J., Fan, W.M., Peng, T.P., Zhang, H.F. Guo, F., 2005. Nature of the Mesozoic lithospheric mantle and tectonic decoupling beneath the Dabie Orogen, Central China: evidence from ${ }^{40} \mathrm{Ar} /{ }^{39} \mathrm{Ar}$ geochronology, elemental and $\mathrm{Sr}-\mathrm{Nd}-\mathrm{Pb}$ isotopic compositions of Early Cretaceous mafic igneous rocks. Chemical Geology 220, 165-189.

Wang, Q., Wyman, D.A., Xu, J.F., Zhao, Z.H., Jian, P., Xiong, X.L., Bao, Z.W., Li, C.F., Bai Z.H., 2006. Petrogenesis of Cretaceous adakitic and shoshonitic igneous rocks in the Luzong area, Anhui Province (eastern China): Implications for geodynamics and $\mathrm{Cu}-\mathrm{Au}$ mineralization. Lithos 89, 424-446.

Wang, Y.J., Fan, W.M., Zhang, G., Zhang, Y., 2013. Phanerozoic tectonics of the South China Block: key observations and controversies. Gondwana Research 23, 1273-1305.

Weis, D., Kieffer, B., Maerschalk, C., Pretorius, W., Barling, J., 2005. High-precision $\mathrm{Pb}-\mathrm{Sr}-\mathrm{Nd}-\mathrm{Hf}$ isotopic characterization of USGS BHVO-1 and BHVO-2 reference materials. Geochemistry Geophysics Geosystems 6(2), Q02002, doi: 10.1029/2004GC000852.

Weis, D., Kieffer, B., Hanano, D., Nobre, Silva, I., Barling, J., Pretorius, W., Maerschalk, C., Mattielli, N., 2007. Hf isotope compositions of U.S. Geological Survey reference materials. Geochemistry Geophysics Geosystems 8(6), Q06006, doi: 10. 1029/2006GC001473.

Wiedenbeck, M., Alle, P., Corfu, F., Griffin, W.L., Meier, M., Oberli, F., von Quadt, A., Roddick, J.C., Spiegel, W., 1995. Three natural zircon standards for U-Th-Pb, Lu-Hf, 
trace element and REE analyses. Geostand Newsletter 19, 1-23.

Wiedenbeck, M., Hanchar, J. M., Peck, W. H., Sylvester, P., Valley, J., Whitehouse, M. Zheng, Y.-F., 2004. Further characterisation of the 91500 zircon crystal. Geostandards and Geoanalytical Research 28, 9-39.

Williams, H.M., Turner, S.P., Pearce, J.A., Kelley, S.P., Harris, N.B.W., 2004. Nature of the source regions for post-collisional, potassic magmatism in southern and northern Tibet from geochemical variations and inverse trace element modelling. Journal of Petrology 45, 555-607.

Woodhead, J.D., Hergt, J.M., 2005. A preliminary appraisal of seven natural zircon reference materials for in situ Hf isotope determination. Geostandards and Geoanalytical Research 29, 183-195.

Wu, G., 2005. The Yanshanian orogeny and two kinds of Yanshanides in eastern-central China. Acta Geologica Sinica 79, 507-518.

Wu, F.-Y., Lin, J.-Q., Wilde, S.A., Zhang, X.-O., Yang, J.-H., 2005. Nature and significance of the First Cretaceous giant igneous event in eastern China. Earth and Planetary Science Letters 233, 103-119.

Wu, F.-Y., Yang, Y.-H., Xie, L.-W., Yang, J.-H. Xu, P., 2006. Hf isotopic compositions of the standard zircons and baddeleyites used in U-Pb geochronology. Chemical Geology 234, 105-126.

Wu, F.Y., Ji, W.Q., Sun, D.H., Yang, Y.H., Li, X.H., 2012. Zircon U-Pb geochronology and Hf isotopic compositions of the Mesozoic granites in southern Anhui Province, China. Lithos 150, 6-25.

Wyllie, P.J., 1984. Constraints imposed by experimental petrology on possible and impossible magma sources and products. Philosophical Transactions of the Royal Society A310, 439-456.

Xie, G.Q., Mao, J.W., Zhao, H.J., 2011. Zircon U-Pb geochronological and Hf isotopic constraints on petrogenesis of Second Mesozoic intrusions in the southeast Hubei Province, Middle-Lower Yangtze River belt (MLYRB), East China. Lithos 125, 693-710.

Xing, F.M., Xu, X., 1994. Two A-type granite belts from Anhui. Acta Petrologica Sinica 1, 357-369 (in Chinese with English abstract).

$\mathrm{Xu}$, Z., Zhao, Z.-F., Zheng, Y.-F., 2012. Slab-mantle interaction for thinning of cratonic lithospheric mantle in North China: geochemical evidence from Cenozoic continental basalts in central Shandong. Lithos 146, 202-217.

Yan, J., Chen, J.F., Xu, X.S., 2008. Geochemistry of Cretaceous mafic rocks from the Lower 
Yangtze region, eastern China: characteristics and evolution of the lithospheric mantle. Journal of Asian Earth Sciences 33, 177-193.

Yan, J., H.Q. Liu., C. Z. Song., X. S. Xu., Y. J. An., J. Liu., L. Q. Dai., 2009. Zircon U-Pb geochronology of the volcanic rocks from Fanchang-Ningwu volcanic basins in the Lower Yangtze region and its geological implications. Chinese Science Bulletin 54, 2895-2904.

Yan, J., Liu, J., Li, Q., Xing, G., Liu, X., Xie, J., Chen, Z., 2015. Insitu Zircon Hf-O Isotopic Analyses of Late Mesozoic Magmatic Rocks in the Lower Yangtze River Belt, Central Eastern China: Implications for Petrogenesis and Geodynamic Evolution. Lithos 227, 57-76.

Yang, Y. H., Wu, F. Y., Wilde, S. A., Liu, X. M., Zhang, Y. B., Xie, L. W., Yang, J. H., 2009. In situ perovskite $\mathrm{Sr}-\mathrm{Nd}$ isotopic constraints on the petrogenesis of the Ordovician Mengyin kimberlites in the North China Craton. Chemical Geology 264, 24-42.

Yang, Y.H., Zhang, H.F., Chu, Z.Y., Xie, L.W., Wu, F.Y., 2010. Combined chemical separation of $\mathrm{Lu}, \mathrm{Hf}, \mathrm{Rb}, \mathrm{Sr}, \mathrm{Sm}$ and $\mathrm{Nd}$ from a single rock digest and precise and accurate isotope determinations of $\mathrm{Lu}-\mathrm{Hf}, \mathrm{Rb}-\mathrm{Sr}$ and $\mathrm{Sm}-\mathrm{Nd}$ isotope systems using Multi-Collector ICP-MS and TIMS. International Journal of Mass Spectrometry 290, 120-126.

Yao, J.L., Shu, L.S., Santosh, M., Zhao, G.C., 2014. Neoproterozoic arc-relatedmafic-ultramafic rocks and syn-collision granite from the western segment ofthe Jiangnan Orogen, South China: constraints on the Neoproterozoic assemblyof the Yangtze and Cathaysia Blocks. Precambrian Research 243, 39-62.

Zhang, Q., P. Jian., D. Y. Liu., Y. L. Wang., Q. Qian., Y. Wang, and H. M. Xue., 2003. SHRIMP dating of volcanic rocks from Ningwu area and its geological implications, Science in China (D) 46, 830-837.

Zhang, S.-B., Zheng, Y.-F., Wu, Y.-B., Zhao. Z.-F., Gao, S., Wu, F.-Y., 2006. Zircon isotope evidence for $\geq 3.5 \mathrm{Ga}$ continental crust in the Yangtze craton of China. Precambrian Research 146, 16-34.

Zhang, J.-J., Zheng, Y.-F., Zhao, Z.-F., 2009. Geochemical evidence for interaction between oceanic crust and lithospheric mantle in the origin of Cenozoic continental basalts in east-central China. Lithos 110, 305-326.

Zhang, S.-B., Wu, R.-X., Zheng, Y.-F., 2012. Neoproterozoic continental accretion in South China: Geochemical evidence from the Fuchuan ophiolite in the Jiangnan orogen. Precambrian Research 220-221, 45-64.

Zhang, S.-B., Zheng, Y.-F., 2013. Formation and evolution of Precambrian continental 
lithosphere in South China. Gondwana Research 23, 1241-1260.

Zhang, S.-B., Tang, J., Zheng, Y.-F., 2014. Contrasting Lu-Hf isotopes in zircon from Precambrian metamorphic rocks in the Jiaodong Peninsula: Constraints on the tectonic suture between North China and South China. Precambrian Research 245, 29-50.

Zhang, S.-B., He, Q., Zheng, Y.-F., 2015. Geochronological and geochemical evidence for the nature of the Dongling Complex in South China. Precambrian Research 256, 17-30.

Zhao, G.C. 2015. Jiangnan orogeny in South China: developing from divergent double subduction. Gondwana Research 27, 1173-1180.

Zhao, Z.-F., Zheng, Y.-F., 2003. Calculation of oxygen isotope fractionation in magmatic rocks. Chemical Geology 193, 59-80.

Zhao, Z.F., Zheng, Y.F., Wei, C.S., Gong, B., 2004. Temporal relationship between granite cooling and hydrothermal uranium mineralization at Dalongshan in China: a combined radiometric and oxygen isotopic study. Ore Geology Reviews 25, 221-236.

Zhao, G.C., Cawood, P.A., 2012. Precambrian geology of China. Precambrian Research 222-223, 13-54.

Zhao, Z.-F., Dai, L.-Q., Zheng, Y.-F., 2013. Postcollisional mafic igneous rocks record crust-mantle interaction during continental deep subduction. Scientific Reports 3, 3413; doi: $10.1038 /$ srep03413.

Zhao, Z.F., Zheng, Y.F., 2009. Remelting of subducted continental lithosphere: Petrogenesis of Mesozoic magmatic rocks in the Dabie-Sulu orogenic belt. Science in China (D): Earth Sciences 52, 1295-1318.

Zheng, Y.-F., Chen, R.-X., Zhao, Z.-F., 2009. Chemical geodynamics of continental subduction-zone metamorphism: Insights from studies of the Chinese Continental Scientific Drilling (CCSD) core samples. Tectonophysics 475, 327-358.

Zheng, Y.-F., Xia, Q.-X., Chen, R.-X., Gao, X.-Y., 2011. Partial melting, fluid supercriticality and element mobility in ultrahigh-pressure metamorphic rocks during continental collision. Earth-Science Review 107, 342-374.

Zheng, Y.-F., 2012. Metamorphic chemical geodynamics in continental subduction zones. Chemical Geology 328, 5-48.

Zheng, Y.-F., Xiao, W.-J., Zhao, G.C., 2013. Introduction to tectonics of China. Gondwana Research 23, 1189-1206.

Zheng, Y.-F., Hermann, J., 2014. Geochemistry of continental subduction-zone fluids. Earth, Planets and Space 66, 93; doi: 10.1186/1880-5981-66-93.

Zheng, Y.F., Chen, Y.X., Dai, L.Q., Zhao, Z.F., 2015. Developing plate tectonics theory from 
oceanic subduction zones to collisional orogens. Science China Earth Sciences 58, 1045-1069.

Zhou, X.M., Li, W.X., 2000. Origin of Late Mesozoic igneous rocks in Southeastern China: implications for lithosphere subduction and underplating of mafic magmas. Tectonophysics 326, 269-287.

Zhou, X.M., Sun, T., Shen, W.Z., Shu, L.S., Niu, Y.L., 2006. Petrogenesis of Mesozoic granitoids and volcanic rocks in South China: a response to tectonic evolution. Episodes 29, 26-33.

Zhou, T.F., Fan, Y., Yuan, F., Zhang, L.J., Qian, B., Ma, L., Yang, X.F., David, C., 2011. Geochronology and significance of volcanic rocks in the Ning-Wu Basin of China. Science in China (D) 54, 185-196.

Zhu, G., Xie, C. L., Chen, W., Xiang, B.W., Hu, Z.Q., 2010. Evolution of the Hongzhen metamorphic core complex: Evidence for First Cretaceous extension in the eastern Yangtze craton, eastern China. Geological Society of America Bulletin 122, 506-516.

Zindler, A., Hart, S., 1986. Chemical geodynamics. Annual review of earth and planetary sciences 14, 493-571. 


\section{Figure captions}

Figure 1. (a) Sketch map showing the distribution of Early Cretaceous volcanic basins, granitoids and associated porphyry-related skarn and stratabound $\mathrm{Cu}-\mathrm{Au}-\mathrm{Mo}-\mathrm{Fe}$ deposits, magnetite-apatite deposits and skarn Fe deposits, along the Middle-Lower Yangtze Valley in South China (modified after Chen et al., 2014). Fault abbreviations: TLF, the Tancheng-Lujiang fault; XGF, the Xiangfan-Guangji fault; YCF, the Yangxing-Changzhou fault; JSBF, the Jiujiang-Shitai buried fault (the suture between the Yangtze Craton and the Jiangnan orogen); ZDF, the Zhenghe-Dapu fault (the suture between the Jiangnan orogen and the Cathaysia terrane). (b) Distribution of Cretaceous volcanic rocks in the Ningwu basin (modified after Tang et al., 2013).

Figure 2. Representative microphotographs for the Ningwu volvanics in the Middle-Lower Yangtze Valley. (a) Patchy zoned plagioclase phenocrysts in the Dawangshan andesite; (b) Patchy zoned clinopyroxene phenocryst and the associated Magnetite and Apatite in the Niangniangshan trachydacite; (c) Euhedral biotite phenocryst and rounded K-feldspar phenocrysts in the Dawangshan trachydacite; (d) Finely spongy cellular texture (also

Figure 3. Concordia diagrams of zircon $\mathrm{U}-\mathrm{Pb}$ isotope data analyzed by the SIMS technique for the Ningwu volvanics in the Middle-Lower Yangtze Valley.

Figure 4. Total alkali versus $\mathrm{SiO}_{2}$ (TAS) diagram for the Ningwu volvanics in the Middle-Lower Yangtze Valley. The classification is after Le Maitre et al. (2002). The solid circle represents samples from this study (Table S2) and the half solid circle represents samples from the literature (Wang et al., 2001; Tang et al., 2013, Yan et al.,

Figure 5. Plots of $\mathrm{SiO}_{2}$ versus major oxides and incompatible trace elements, $\mathrm{Mg \#}$ versus $\mathrm{Cr}-\mathrm{Ni}$ for the Ningwu volvanics in the Middle-Lower Yangtze Valley. The data sources and symbol meaning are the same as in Fig. 4. 
Figure 6. Chondrite-normalized REE patterns and primitive mantle-normalized trace element patterns for the Ningwu volcanics in the Middle-Lower Yangtze Valley. The chondrite values and the primitive mantle values are after McDonough and Sun (1995). The data sources are the same as in Fig. 4.

Figure 7. The initial Sr-Nd-Pb-Hf isotope correlation diagrams for the Ningwu volvanics in the Middle-Lower Yangtze Valley (calculated at $\mathrm{t}=130 \mathrm{Ma}$ ). The mantle, oceanic sediment arrays are after Chauvel et al. (2007) and Vervoort et al. (2011), respectively. The Northern Hemisphere Reference line (NHRL) is after Zindler and Hart (1986). Light green field denotes the $\mathrm{Sr}-\mathrm{Nd}-\mathrm{Pb}-\mathrm{Hf}$ isotope compositions of the alkali-rich rocks in the Luzong basin (Wang et al., 2006; Chen et al., 2014), the light red field denotes the $\mathrm{Sr}-\mathrm{Nd}-\mathrm{Pb}-\mathrm{Hf}$ isotope compositions of the Mesozoic mafic rocks in the Middle-Lower Yangtze Valley (Wang et al., 2006; Yan et al., 2008; Xie et al., 2011; Tang et al., 2012, 2013; Chen et al., 2014; Yan et al., 2015) and the cyan field in Figure 7a denotes the $\mathrm{Sr}-\mathrm{Nd}$ isotope compositions of Mesozoic mafic igneous rocks in the Dabie orogen (Wang et al., 2005; Huang et al., 2007; Dai et al., 2012). Data sources and the symbol meaning are the same as in Fig. 4.

Figure 8. Zircon $\delta^{18} \mathrm{O}$ values for the Ningwu volcanics in the Middle-Lower Yangtze Valley. Gray field denotes the normal mantle zircon $\delta^{18} \mathrm{O}$ values (Valley et al., 1998) and the light yellow field denotes the whole-rock $\delta^{18} \mathrm{O}$ values of the continental arc andesites (Bindeman et al., 2008).

Figure 9. Histograms of zircon $\varepsilon_{\mathrm{Hf}}(\mathrm{t})$ values and two-stage $\mathrm{Hf}$ model ages for the Ningwu volcanics in the Middle-Lower Yangtze River Belt.

Figure 10. Plots of $\mathrm{Sr} / \mathrm{Y}$ versus $\mathrm{Y}$ and $(\mathrm{La} / \mathrm{Yb})_{\mathrm{N}}$ versus $\mathrm{Yb}$ classifications for the Ningwu volcanics in the Middle-Lower Yangtze Valley (after Drummond and Defant, 1990). Data sources and the symbol meaning are the same as in Fig. 4.

Figure 11. Correlation diagrams between $(\mathrm{La} / \mathrm{Yb})_{\mathrm{N}}$ ratios and initial $\mathrm{Sr}-\mathrm{Nd}-\mathrm{Pb}-\mathrm{Hf}$ isotope ratios for the Ningwu volcanics in the Middle-Lower Yangtze Valley. Data sources and the symbol meaning are the same as in Fig. 4. 
Figure 12. Correlation diagrams between $\mathrm{SiO}_{2}$ content and initial $\mathrm{Sr}-\mathrm{Nd}-\mathrm{Pb}-\mathrm{Hf}$ isotope ratios for the Ningwu volcanics in the Middle-Lower Yangtze Valley. Data sources and the symbol meaning are the same as in Fig. 4.

Figure 13. Plots of the thermaldynamic modeling results using MELTS with the $\mathrm{SiO}_{2}, \mathrm{MgO}$ and $\mathrm{K}_{2} \mathrm{O}$ concentrations of the Ningwu volcanics. The lines denote the equilibrium crystallization paths of basaltic and andesitic melts starting from their liquidus temperature. The paths are calculated using MELTS (Gualda and Ghiorso, 2015 and references therein), the composition of the starting materials and their sources as well as the physicochemical parameters for this modeling are present in Table 4. Lines 1 and 2 denote the fractional crystallization of primary K-poor basaltic and andesitic melts in equilibrium with normal peridotite with silica contents of 51.7 wt.\% and 57.8 wt.\%, respectively. Lines 3, 4, 5 and 6 denote fractional crystallization of primary K-rich basaltic and andesitic melts in equilibrium with phlogopite-bearing peridotite with silica contents of 52.1, 56.9, 58.0 and 60.1 wt. \%, respectively. Numbers on the fractional crystallization paths denote the extents of crystallization. The shadow area denotes the potential compositional correlation patterns for the mafic igneous rocks that are produced by conceptual mixing between primary basaltic and andesitic melts after certain extent of fractional crystallization.

Figure 14. Cartoon illustrating a petrogenetic model for the Late Mesozpoci mafic magmatism in the Middle-Lower Yangtze Valley (MLYV), South China. The slab-mantle interaction in oceanic subduction channel is assumed as a physico-chemical mechanism for the formation of mantle sources for these andesitic rocks. Panels: (a) Precambrian subduction of the oceanic crust and the following dehydration melting of the subducted metasediment at the slab-mantle interface, giving rise to felsic melts that react with the overlying mantle wedge peridotite to generate fertile and enriched metasomatites in the mantle wedge; (b) storage of the metasomatites in the orogenic mantle wedge for several hundreds of millions of years; (c) lithospheric extension in the Mesozoic triggered partial melting of the more fertile lithology, leading to the early stage magmatism in the MLYV and the consumption of fertile minerals in the mantle sources; (d) partial melting of the less fertile lithology leads to the late stage magmatism that gave rise to alkaline andesites with exhausting of the fertile minerals, which finally lead to the termination of andesitic magmatism in the Middle-Lower Yangtze Valley. 


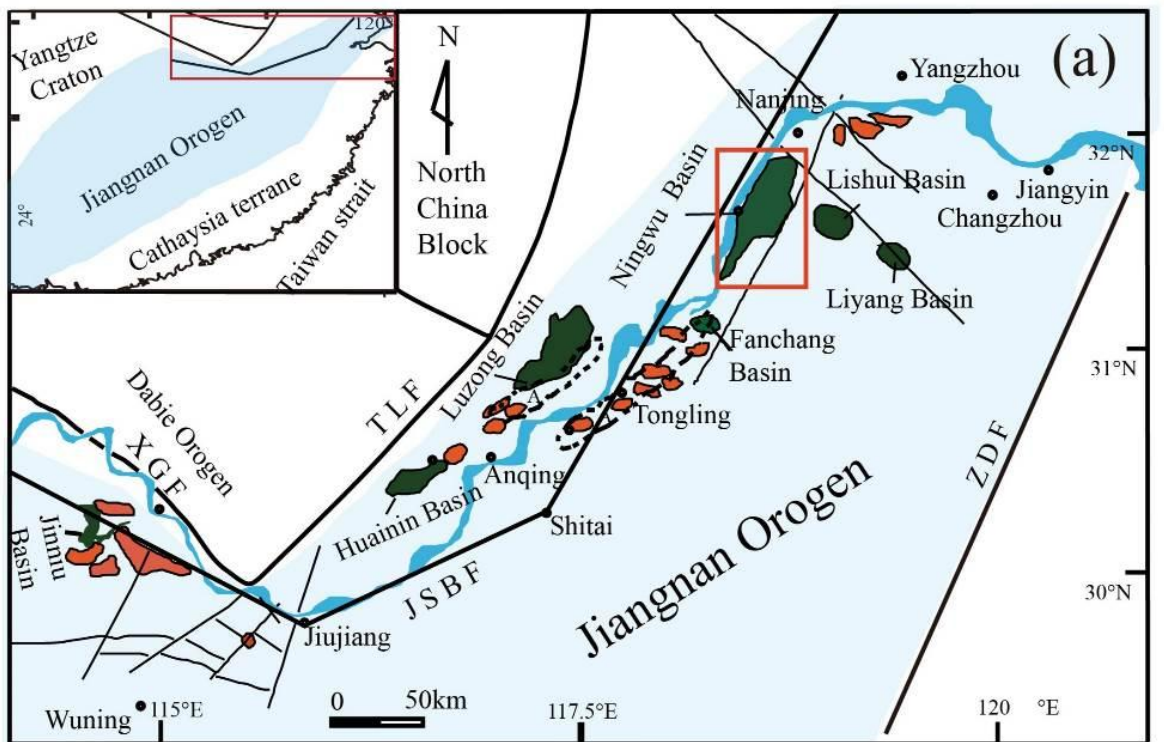

Legend

(a)

Cretaceous volcanic and subvolcanic rocks

Late Jurassic-Early Cretaceous granitoids

A-type granitoids belt

$\square$ Fault zone

(b)

Longwangshan formation

Dawangshan formation

Gushan formation

Niangniangshan formation

A Sample Location

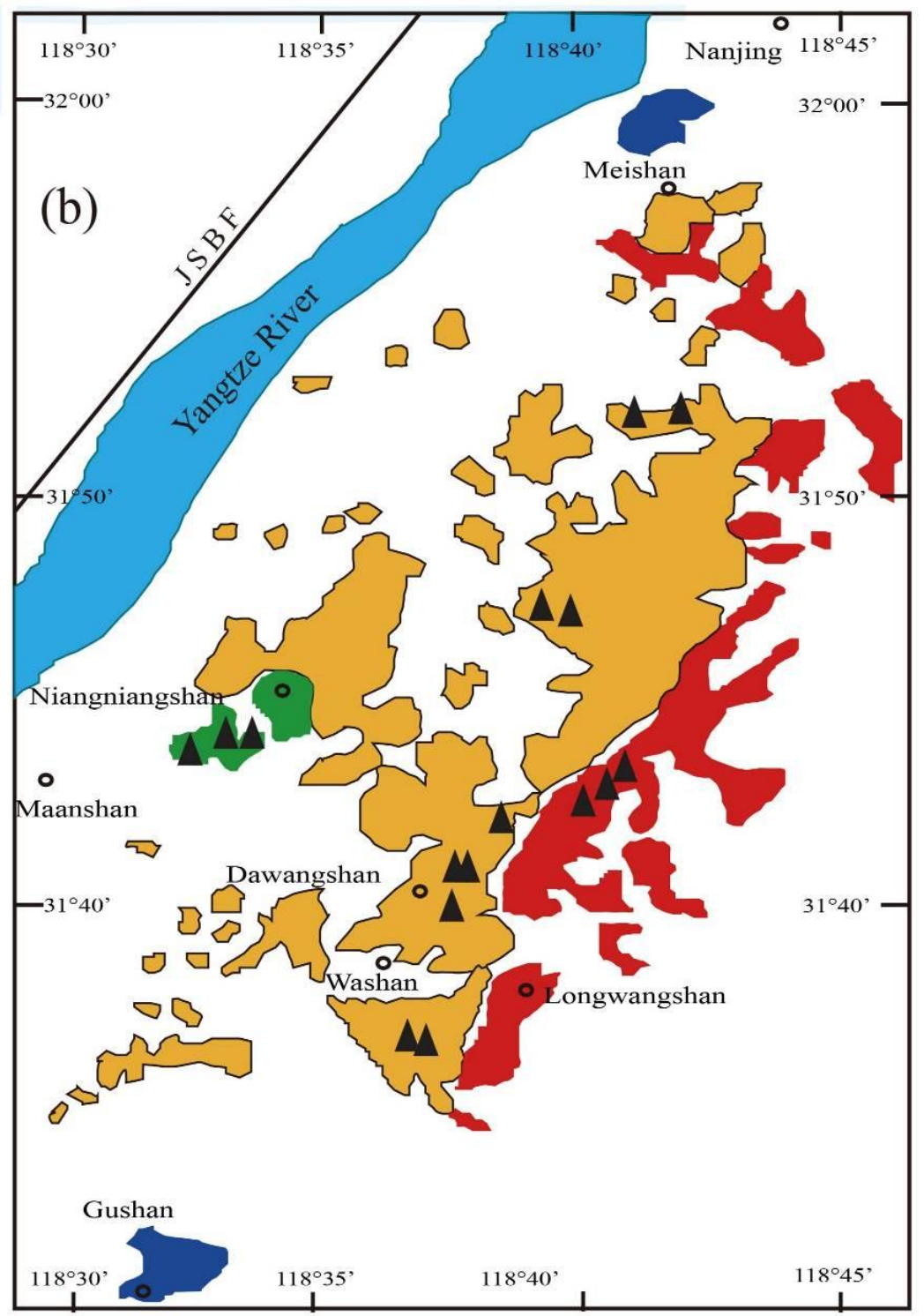

Figure 1 

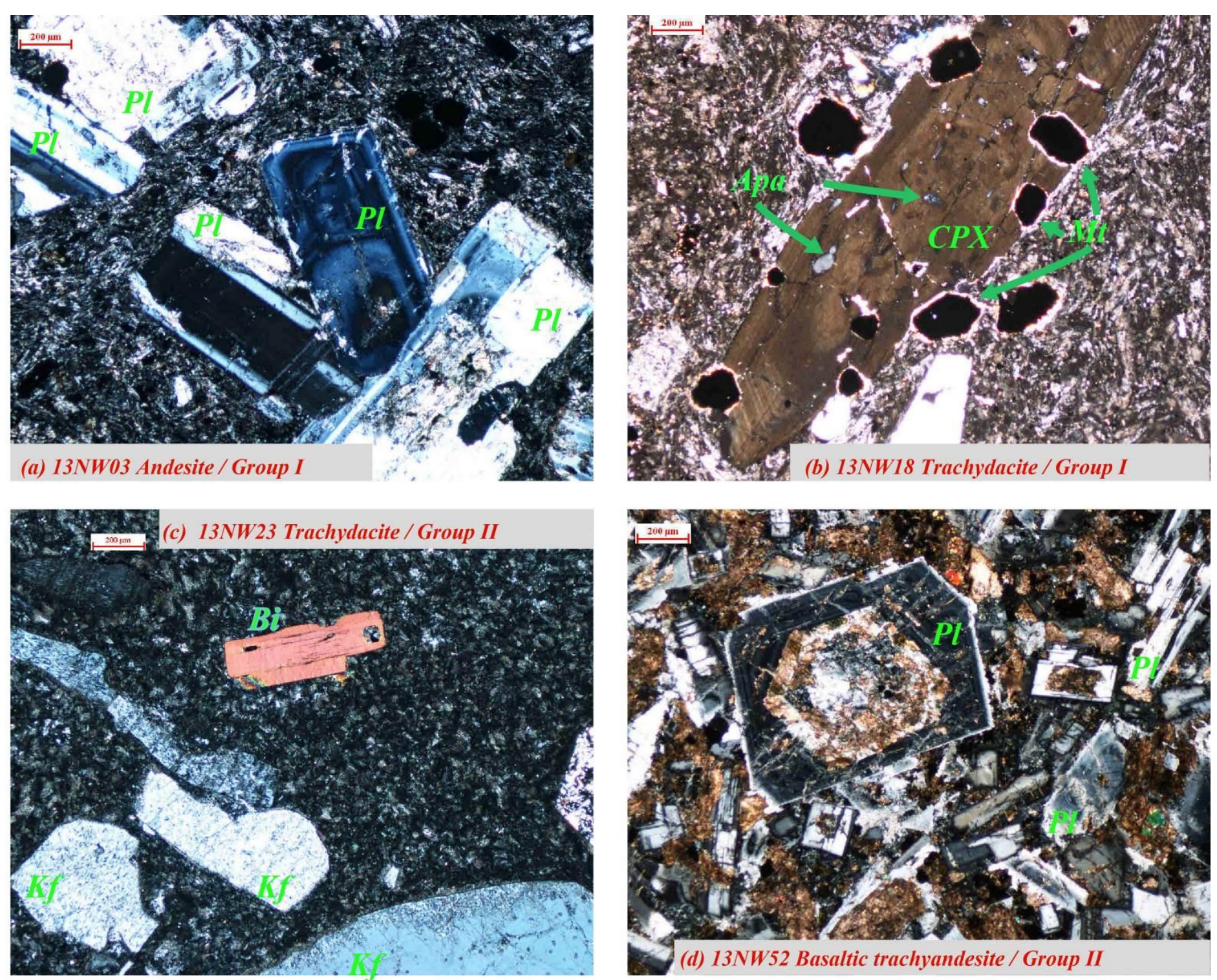

Figure 2 

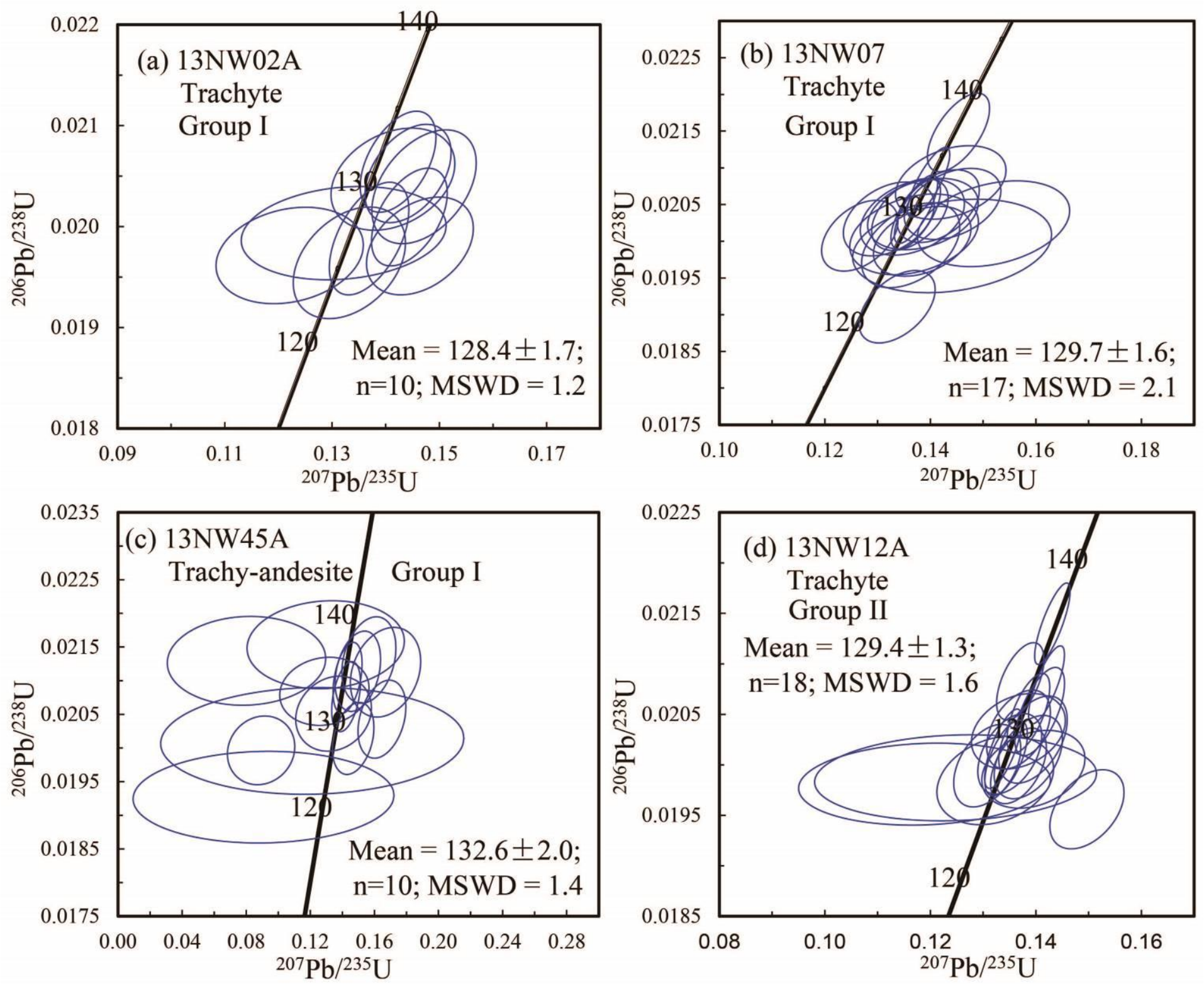

Figure 3 


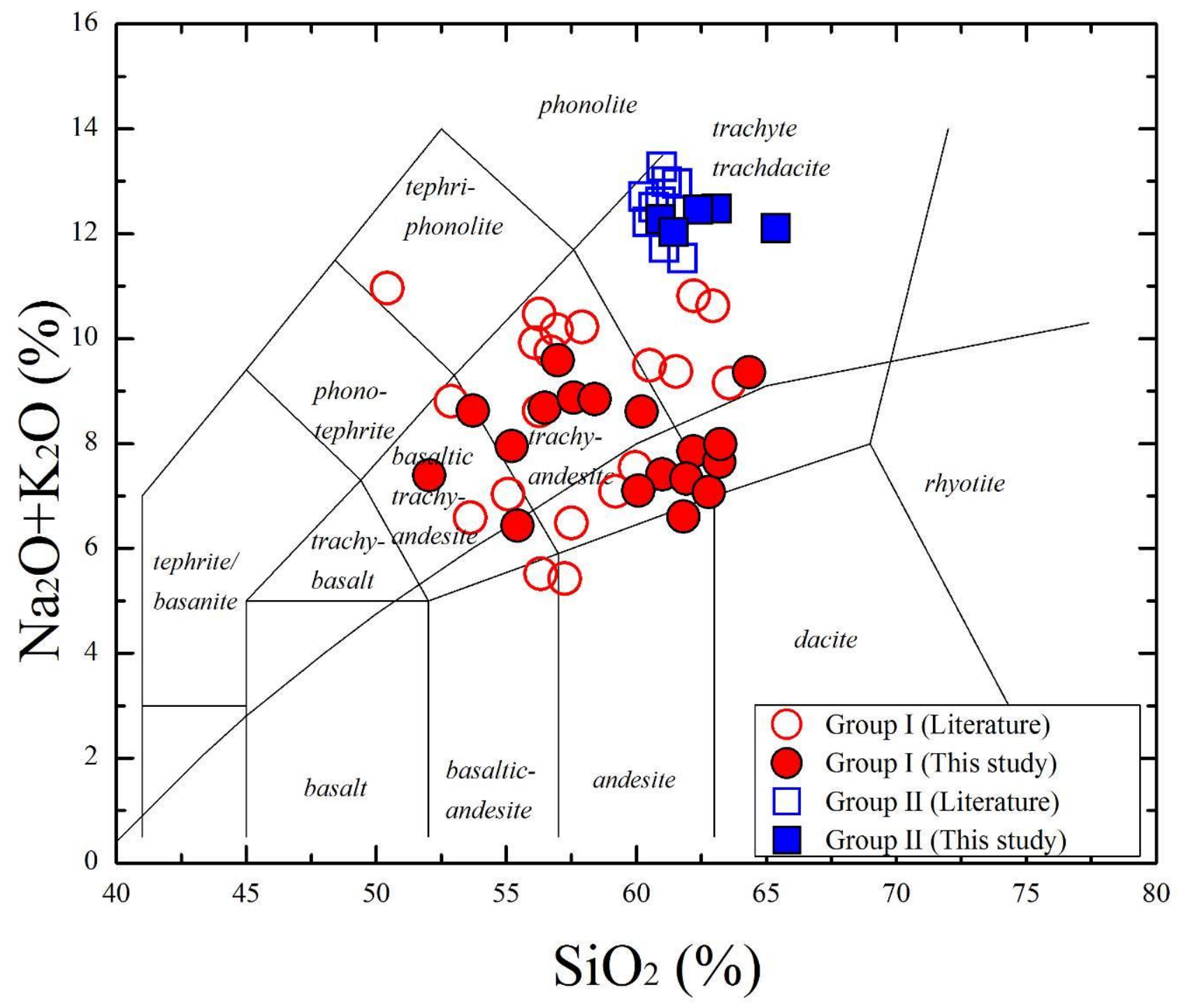

Figure 4 


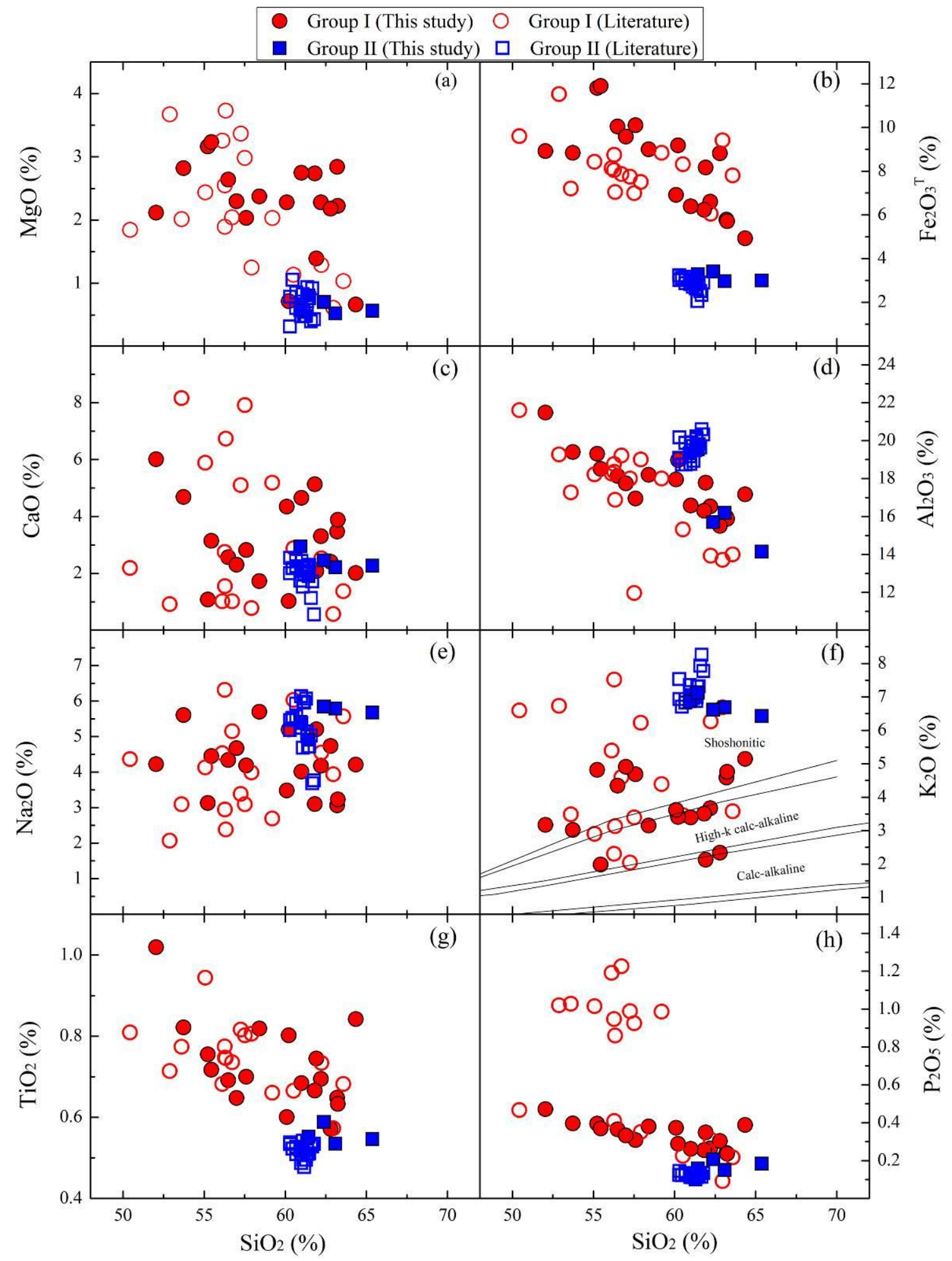

Figure 5(a-h) 

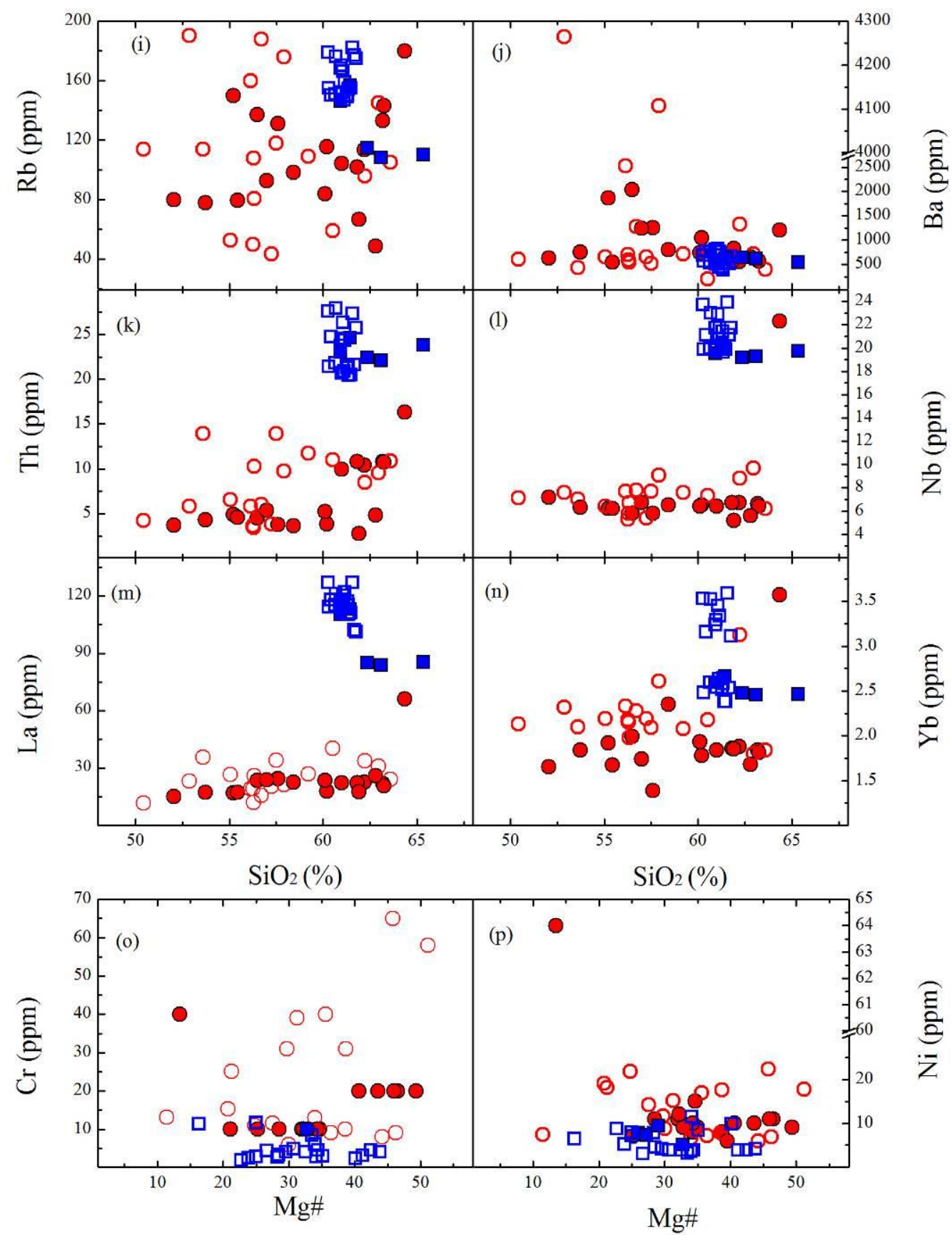

Figure 5(i-p) 

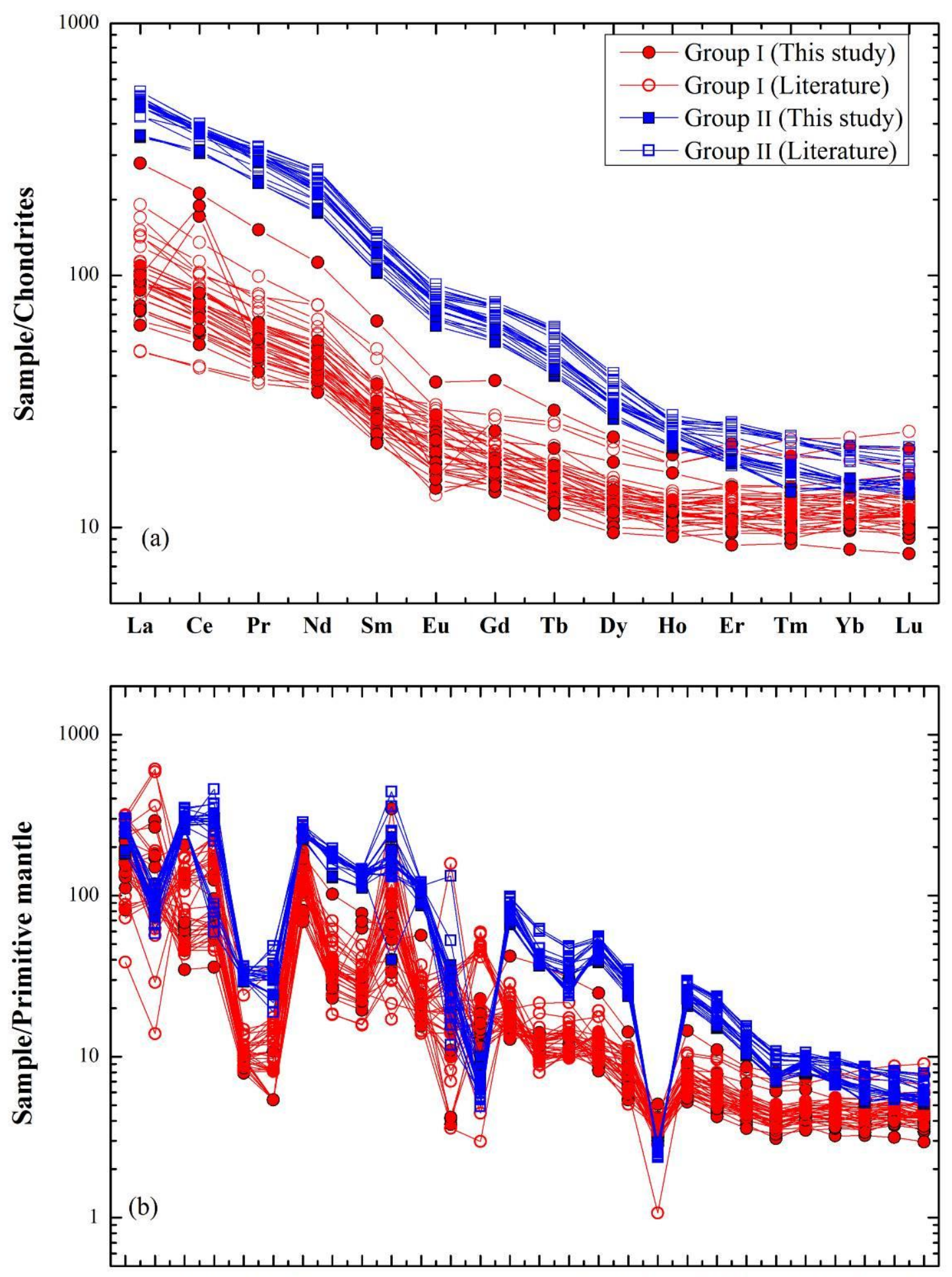

Rb Ba Th U Nb Ta K La Ce Pb Pr Sr P NdZr HfSm Eu Ti GdTb Dy Y Ho ErTmYb Lu

Figure 6 

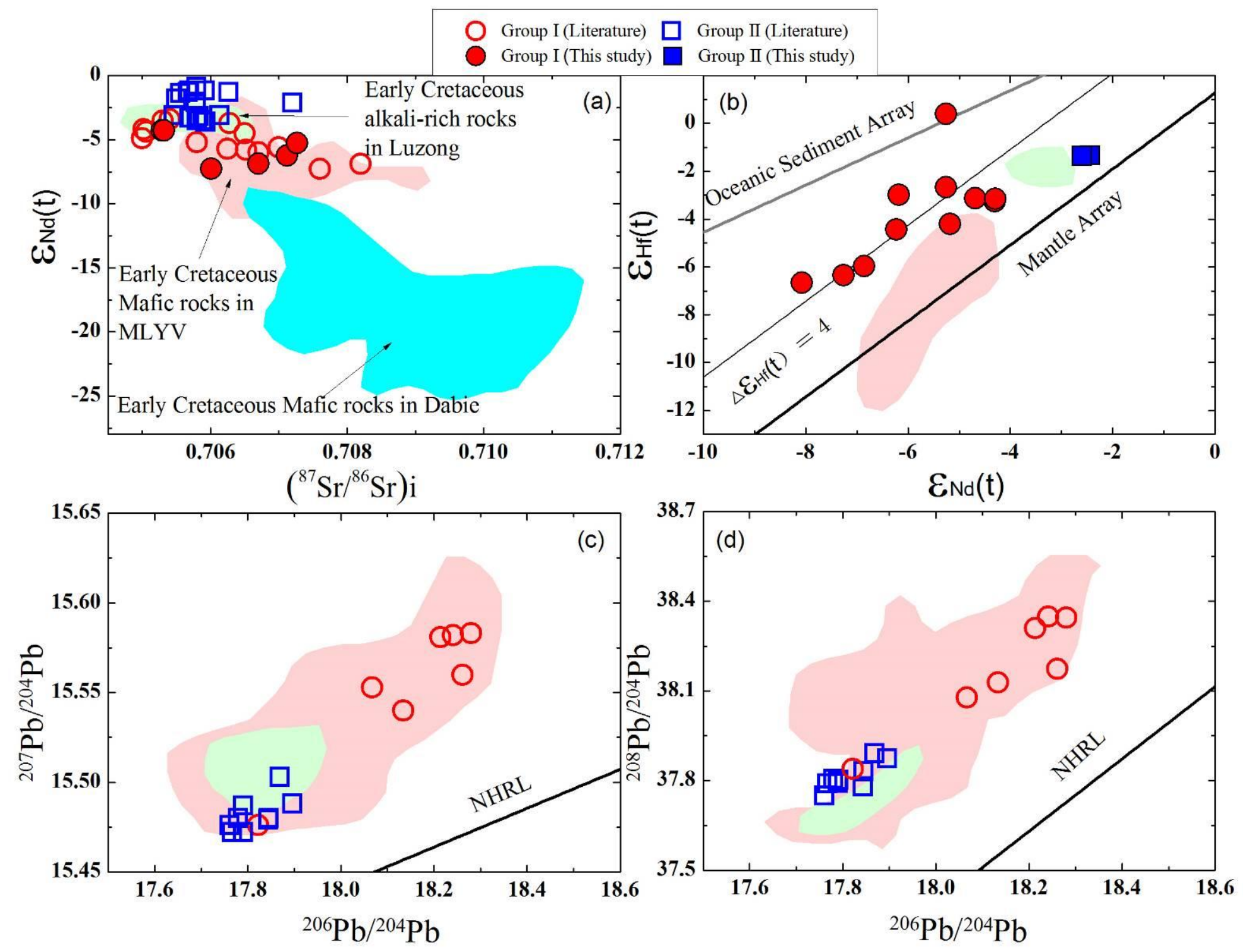

Figure 7 

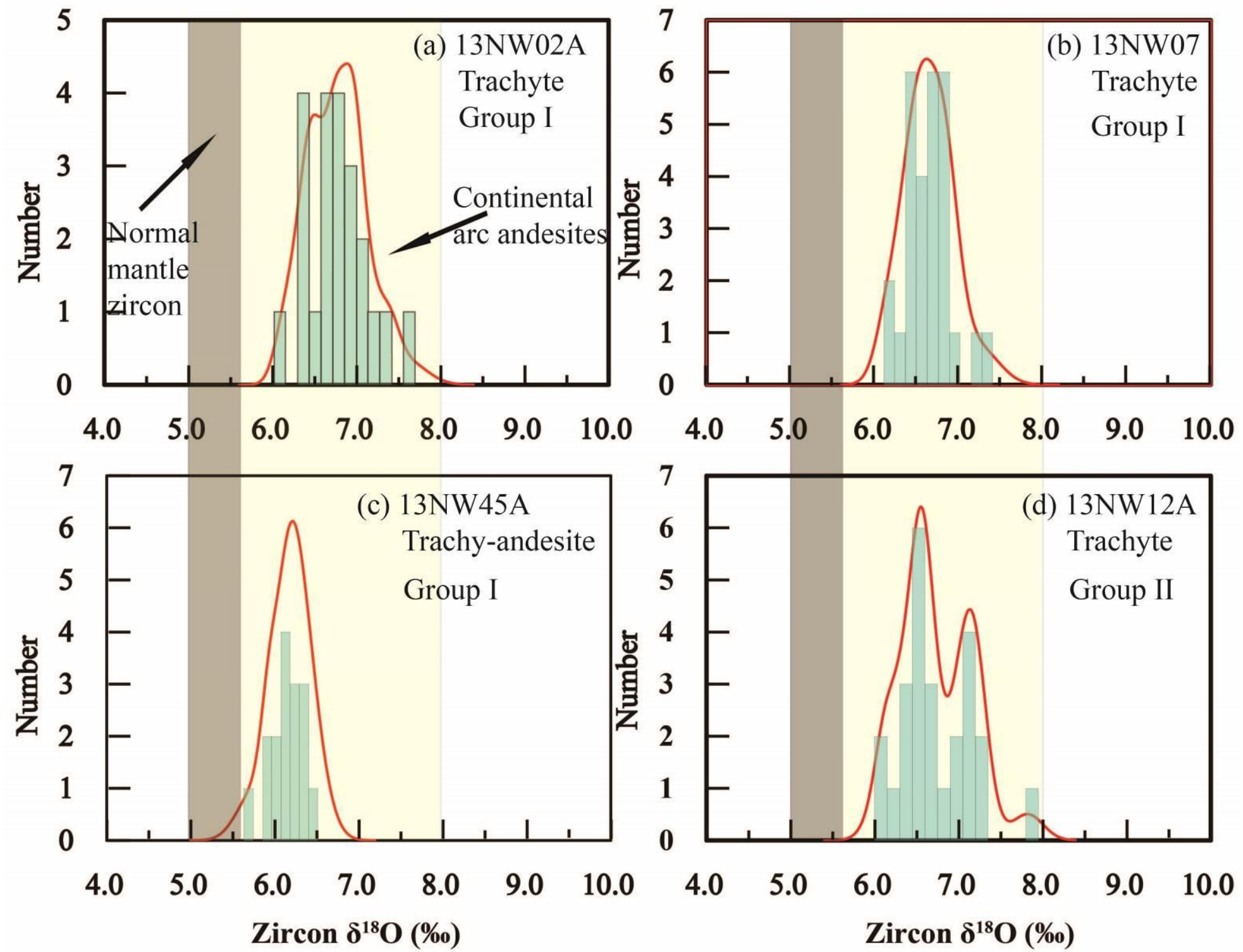

Figure 8 

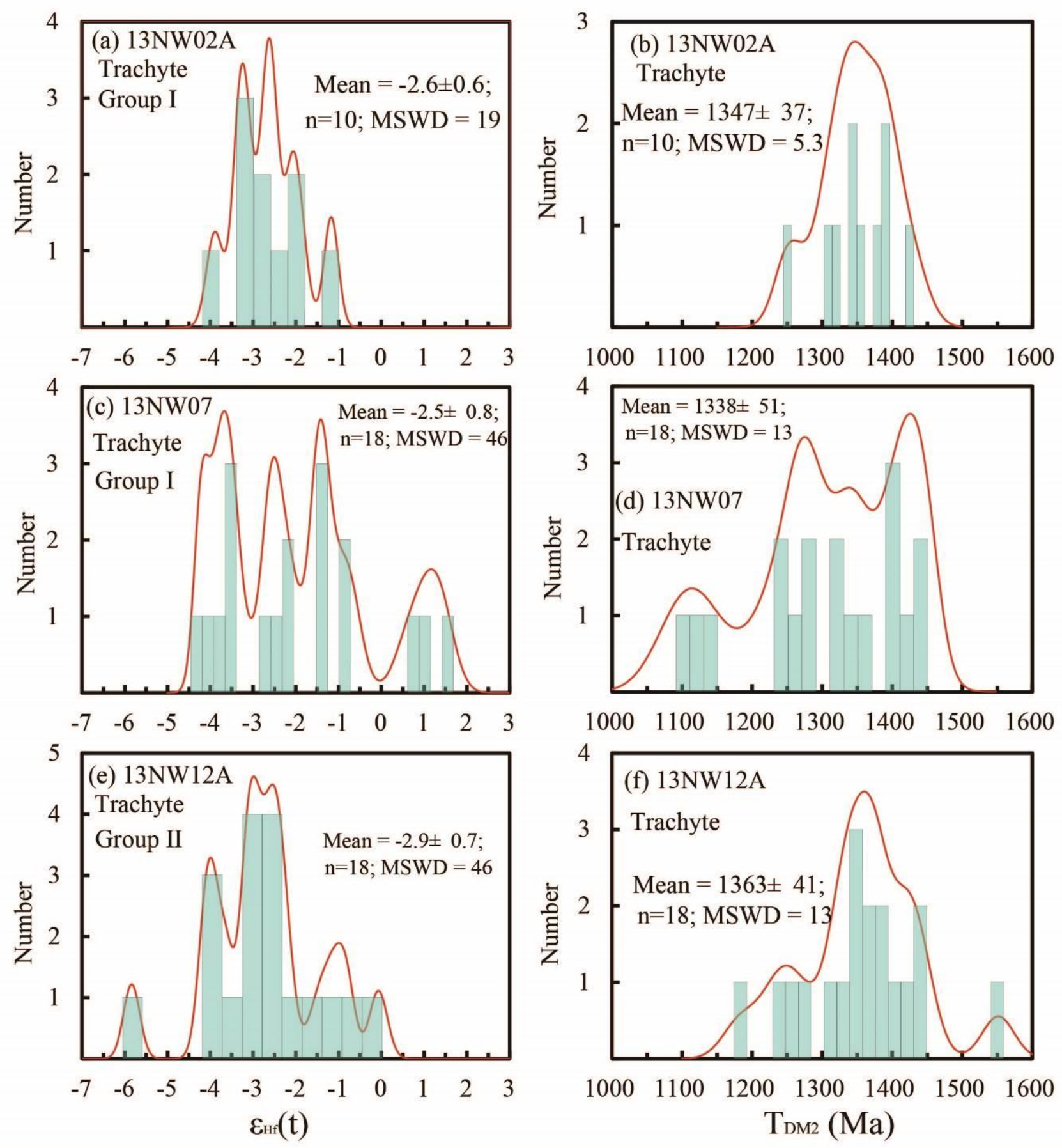

Figure 9 

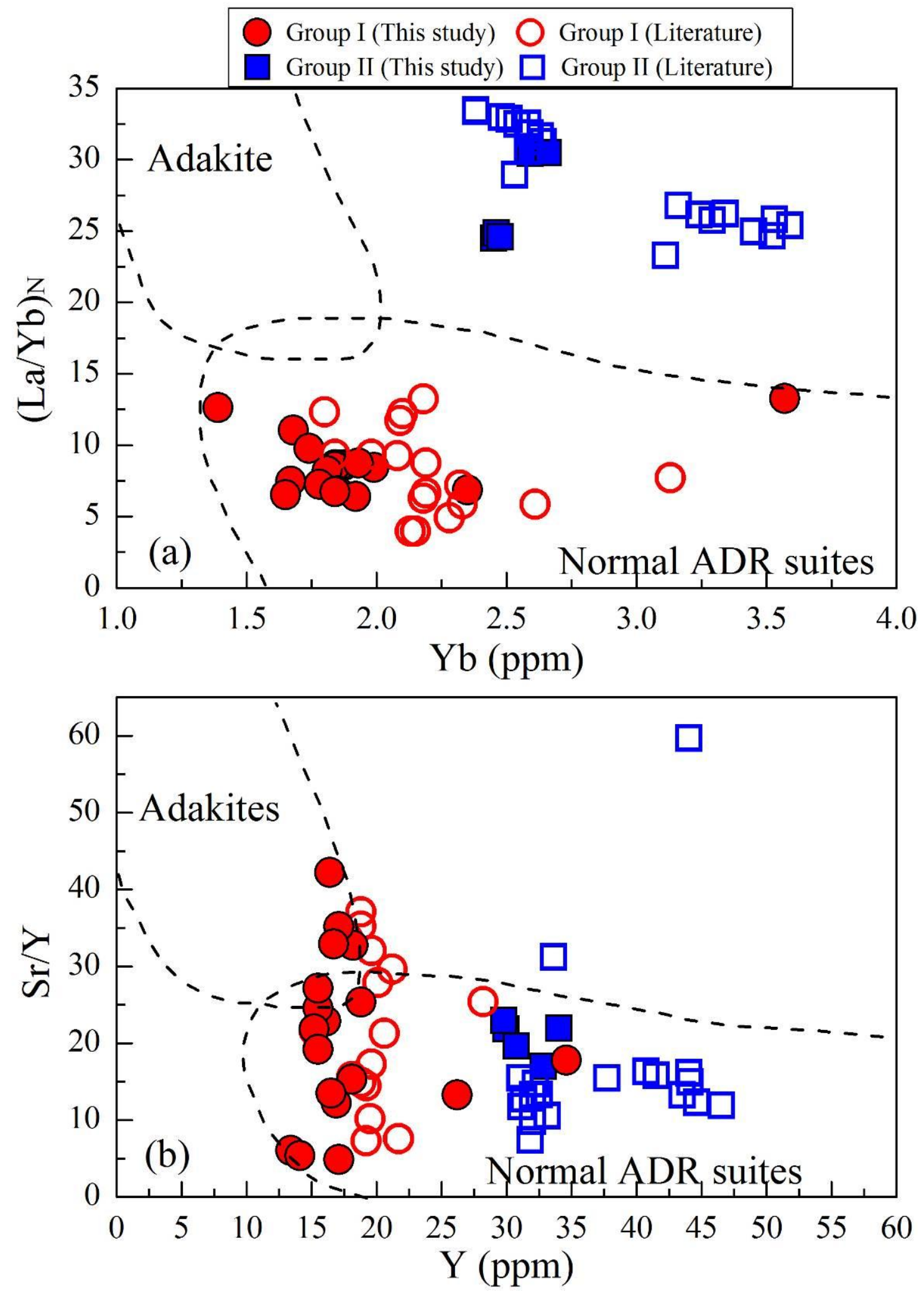

Figure 10 


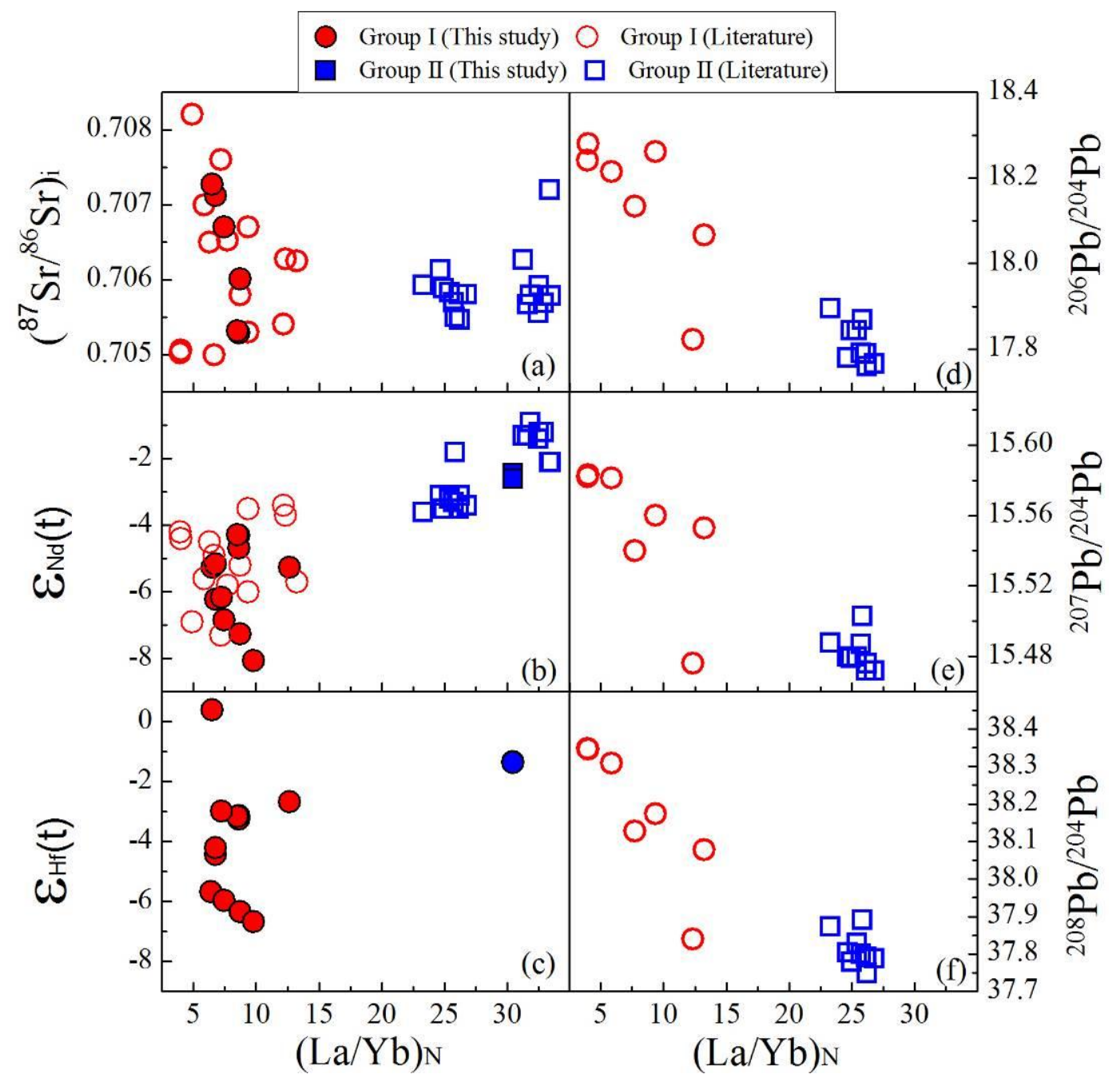

Figure 11 


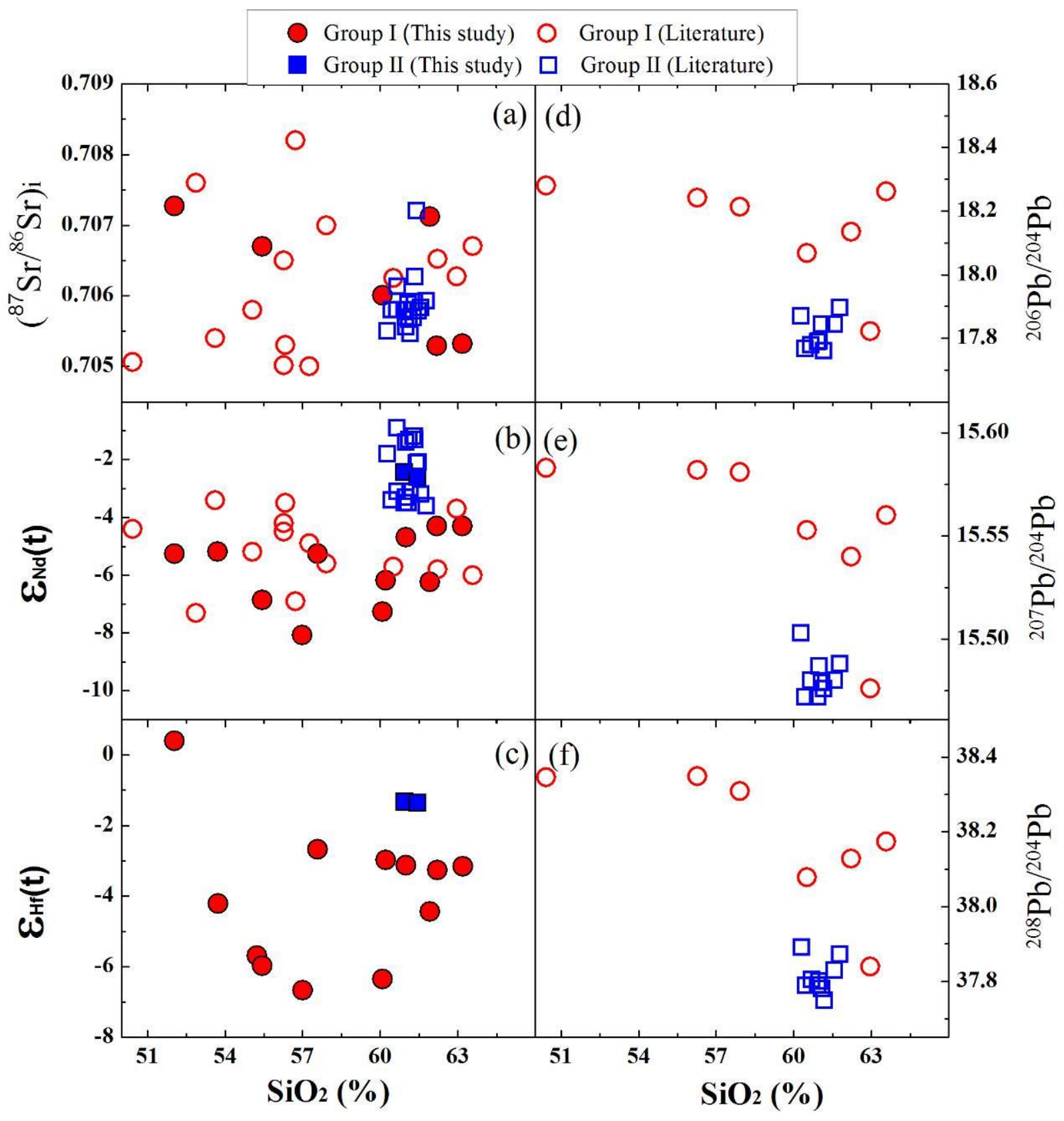

Figure 12 


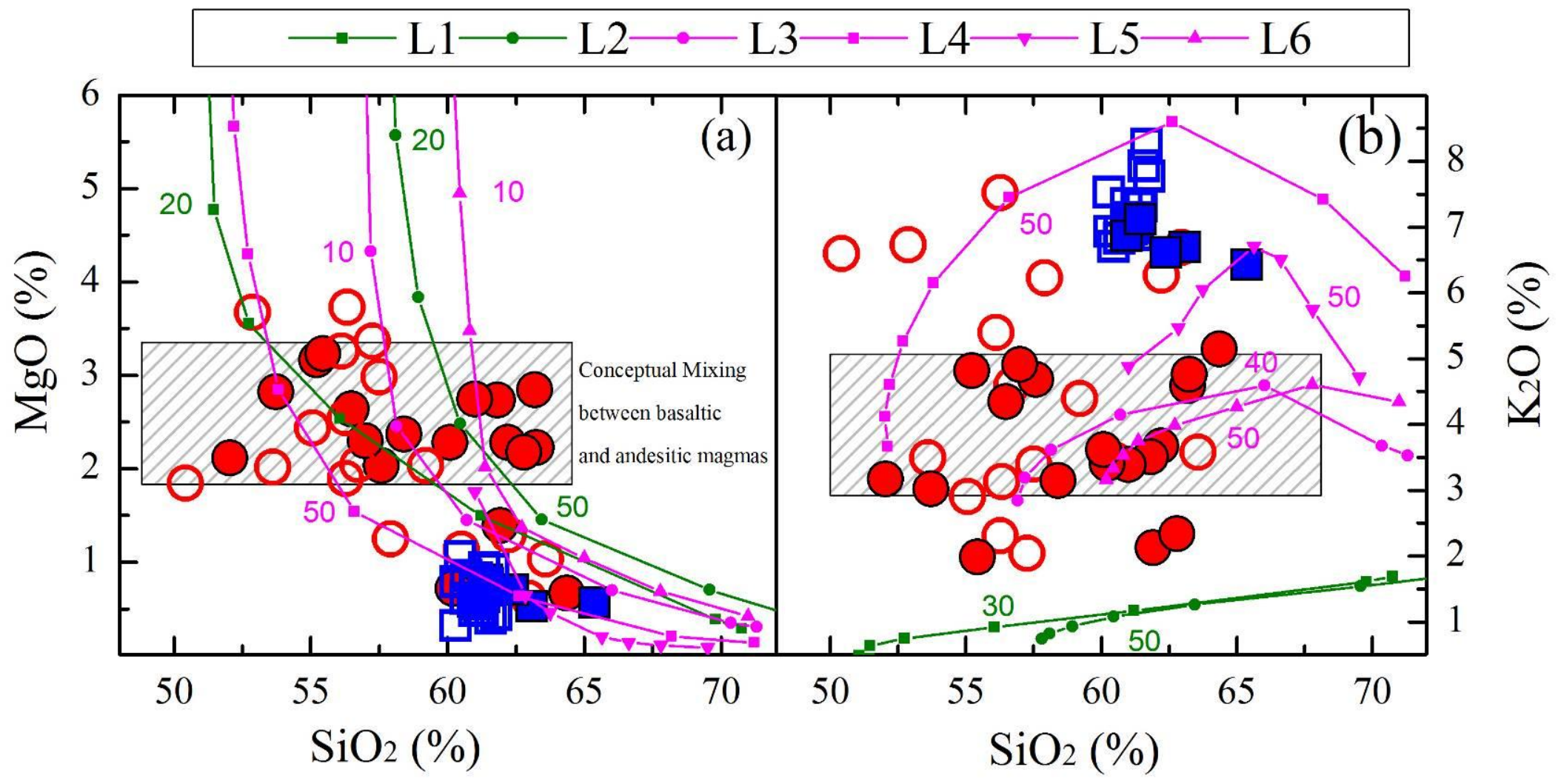

Figure 13 

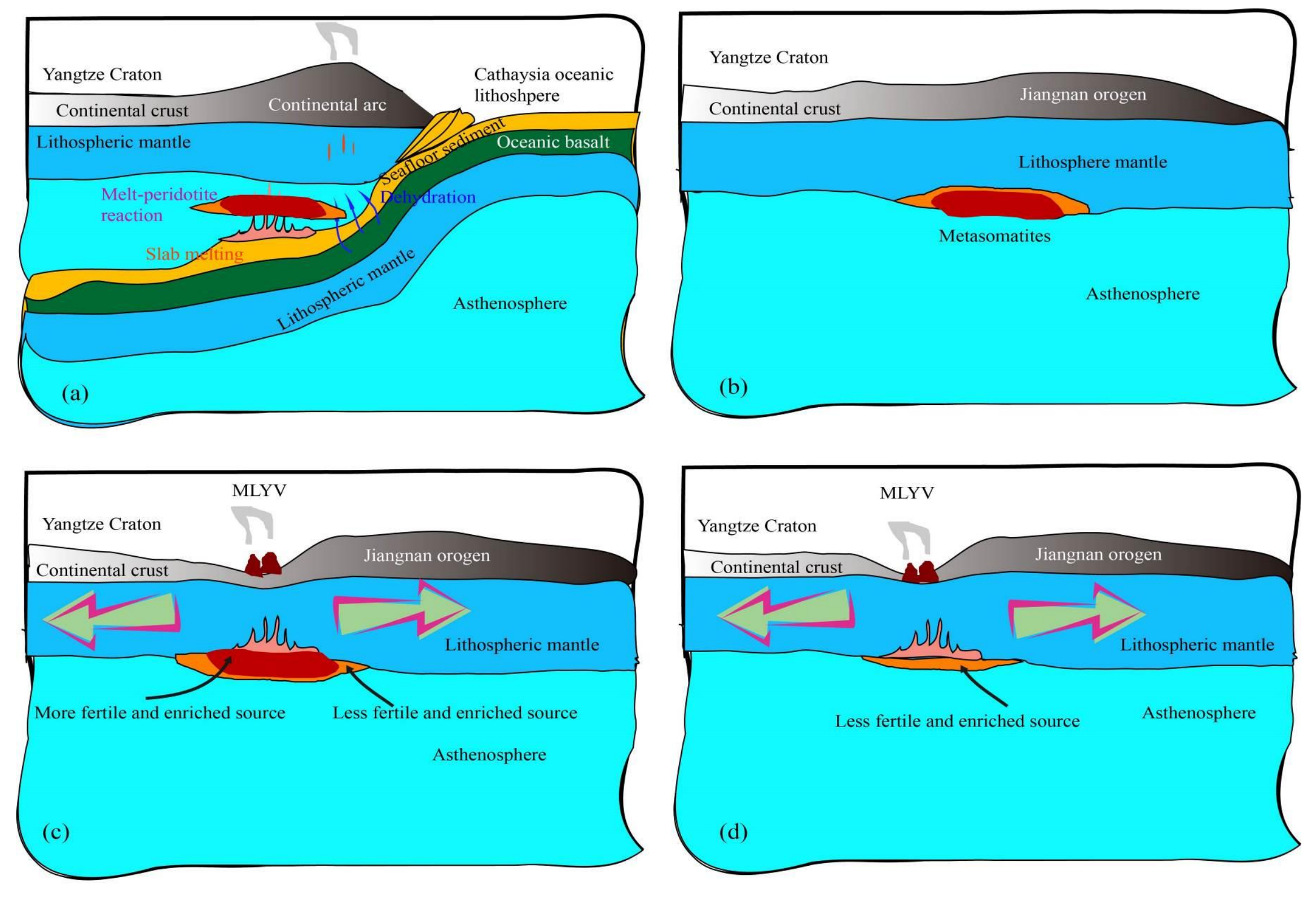

Figure 14 